\title{
EVERYTHING WE HOPED FOR
}

\section{PIP ADAM}

A thesis submitted to Victoria University of Wellington in fulfilment of the research requirements for the degree of Master of Arts in Creative Writing. 
For Brent and Tallulah 


\section{CONTENTS}

5 A Bad Start

11 The Kiss

21 I Believe In Jim Jones

24 Funny Too

26 One Of Your Skies Today

33 Drowning-Baby Prayer

35 Over Again

42 Christchurch

44 When You're Sick

46 I Had Nothing To Do With It

49 Dairyland

53 Everything

62 Jesus Already Has

68 Haydon's Picture 
$74 \quad$ You Might Be Right

78 Exit Wound

80 Until Friday

83 You've Come A Long Way, Baby

90 The Start Of Something For Me

96 For Christmas

107 An In-Joke

110 The Shit Women Talk

119 A Bad Word

124 Hank Nigel Coolidge

127 Maybelline's Baby

131 Cuckolded

133 Like A Good Idea

$140 \quad$ Bleeding

146 Shopping

151 A Village

155 Someone Raises His Eyes

159 Daisy

166 Acknowledgements 


\section{A BAD START}

\section{'LOOK AT MY WATCH.' The anaesthetist was holding his wrist so}

Ruth could read the time. The baby cried as the second hand struck eleven o'clock. 'It's a girl,' Nicholas said. As they lifted it over the screen, Ruth saw it was hideous. A doctor took the baby away, leaving Ruth numb from the shoulders down, arms out like Jesus. Most of the people in the operating room followed the baby. Two surgeons stayed to sew up her stomach. Ruth heard them saying, 'floppy uterus' more than once. She turned her head back to the anaesthetist and said, 'I'm going to be sick.' One of the nurses held a plastic container in front of her face. Nicholas came and sat beside her with the baby. It was screaming. He started to sing. 'I'm going to be sick,' Ruth told him. When the baby cried, it sounded like something was strangling it from deep inside. Her midwife came to where Ruth's head was.

'I'm not staying here,' Ruth said. 'I want to go home.'

'You can't walk,' the midwife said. 'You have to stay here.'

'I could walk before they stuck a needle in my back. I want to go home.' 
'Well,' the midwife stroked her hair, 'you can't walk now, so you have to stay here.'

Ruth, Nicholas and the baby were the only people in the recovery room. The nurse had left. 'Get me more ice,' Ruth said. Nicholas took the polystyrene cup and filled it with ice from a chilly bin near the desk. The baby sucked and slept. Ruth crunched through the ice and said, 'Get me more ice.'

About an hour later, someone came and wheeled Ruth, the baby and the bed into an elevator, and then into a room. A nurse told Nicholas he had to go. Ruth wanted to sleep. There was another baby in the room, another woman, behind a curtain next to Ruth's bed. The other baby cried then Ruth's baby cried. Ruth rolled over; they'd put her baby in a small, plastic box - like the fishbowls in primary school classrooms. She put her hand in the box and rubbed the baby's stomach. 'Shh,' she said, 'Shh.' The baby stopped crying and Ruth rolled onto her back. 'What a bad start,' she said.

Ruth's section of the room was still dull when the sun came up. Curtains cut her off from the other woman and the only window. Curtains cut her off from the wall, the sink and the door people came in and out of. The baby slept and Ruth lay on her back, looking at the ceiling. Fluorescent tubes came on above her; the woman behind the curtain went to the bathroom and had a shower.

Someone wearing a white smock pulled the curtains back, looked at Ruth's catheter bag, lifted her sheets and said, 'Good grief. Someone should have changed these. Did no one change these?' Ruth shook her head. 'Your baby needs feeding.' The woman in the smock started winding the bed up. 'I know it's nice to have a rest but you need to wake that baby up and feed it.' She looked at Ruth's chart, 'Have you had pain relief?' Ruth wasn't sure. They'd given her the injection in her spine before the caesarean and there was a drip in her arm. The woman wrote something down and said, 'You should stand up and have a shower. You'll feel 
better once you're moving again.' While the woman changed the bloody sheets, Ruth stood like she was on a ledge holding the tube for her catheter in one hand and the frame her drip was attached to in the other. The baby slept. Ruth got back into bed and the woman checked her dressings. 'When you have a shower you need to take these off.' She meant the bandages. 'If you can't take them off, get one of the nurses to take them off. You can't have a shower till they take the catheter and the drip out.' The woman took the baby out of the plastic box and gave it to Ruth, 'You need to feed the baby,' and then she went out, leaving the curtain open.

Ruth tried to remember the diagram from ante natal class. The one with the baby's cheek cut out so you could see the nipple in its mouth. She was pretty sure she wasn't doing it right but it would look right to anyone passing by the open door. Like the Madonna. She wasn't sure how long to feed the baby for but every time it cried she really wanted to feed it and it cried every time it stopped sucking, so she kept feeding it. An hour later Nicholas arrived.

'You're feeding the baby,' he said.

'They said I have to have a shower and take the bandages off.'

'Oh.'

'I don't want to take the bandages off.'

'Have you stood up already?' He touched the back of the baby's head.

'Yeah, while they changed my bed. There was blood everywhere - it looked like something dreadful had happened.'

Nicholas nodded. 'How long have you been feeding her?'

'A couple of hours,' Ruth arched her back.

'Have you had breakfast?'

'They won't give me anything to eat until I fart,' she said, 'to make sure they've put my bowels back in properly, or something.'

'Oh,' he looked up from the baby for the first time, 'so it's pretty much exactly as we'd dreamed.'

'Everything we hoped for,' she said. 
They both laughed. Nicholas looked at the baby again dropping his head from side to side, 'She's very cute, you know?' The baby had nodded off and was rubbing its face with its tiny hands.

'Her head's gone down a bit,' Ruth said, rubbing the place where the lump was.

'And she's not blue,' Nicholas said.

There was a birthing pool set up in their spare room at home. They'd put it together when the baby was a week overdue; to cheer themselves up and give the baby some encouragement. Nothing happened. Ruth walked up hills, moved the refrigerator, ate curry and did everything else the midwife suggested. When the baby was two weeks overdue the midwife sent them for a scan. The radiologist said, 'This is never coming out - it's huge.' Their midwife said, 'She shouldn't have said that. That's pretty unprofessional.'

Seventeen hours into the induced labour a registrar mentioned the word caesarean. Ruth said to Nicholas, 'You talk to her, I can't talk to her, I'm not staying here another night.' He talked to the midwife, then came back and said Ruth and the baby had to stay at the hospital if there was a caesarean. Ruth said, 'There's a motel across the road. I'll stay there. Tell her that.' Nicholas went away, came back and said if there was a caesarean Ruth would have a catheter and a drip; she would have to stay in the hospital with the baby.

Every time someone came to look at Ruth's chart they said, 'Failure to progress,' and 'Have you had pain relief?' Nicholas made notes on the back of his hand with a pen because Ruth couldn't remember and no one who worked at the hospital seemed to know. That afternoon, someone took the drip and the catheter out, but not before Nicholas's father visited and made a joke about the bag hanging off the side of Ruth's bed. Nicholas held the baby and walked around the room while Ruth went to the shower and looked at the bandages. After a few tentative pulls 
she abandoned taking them off. She had no idea what was under them. She was sore and she didn't want to be more sore. She put the hospital gown in the laundry bag in the bathroom and came out wearing her own clothes.

'Is that better?' Nicholas said.

'Yeah, heaps.'

That evening one of the nurses decided the baby wasn't getting enough food. 'It needs formula.' Ruth said no. 'Well, you'll have to express, to try and speed things up.' The nurse went away and came back with a syringe without a needle and a diagram showing how to hand-express. It was like milking a cow and being a cow at the same time. Ruth sucked a tiny amount of watery colostrum into the syringe. The nurse took Nicholas and showed him where to put it in the ward fridge. Ruth dozed, and when the baby woke up said, couldn't Nicholas go and get the stuff from the fridge and give it to the baby so she could sleep some more. He went and came back and said someone had taken it. Someone else's baby was drinking Ruth's milk.

At home, around the birthing pool, they'd put pillows and a CD player. She would have the baby, then they would all crawl into bed for a couple of days. Feeding, eating, staying warm. People would visit them and they would hang a sign up when they were sleeping. No one that visited would drink her breast milk.

Around ten thirty a nurse came and told Nicholas to go home and took Ruth's bandages off. The baby woke up, crying. She fed the baby for another three or four hours. The woman behind the curtain shouted out for Ruth to keep the baby quiet because it was waking up her baby. Ruth took the baby and the blanket her mother had knitted and went to the television lounge. There was a vampire movie on. The baby dozed in her arms. Ruth walked slowly back to her room and put the baby in the plastic crib. She got herself into bed and shut her eyes. The baby woke up half an hour later. The woman behind the curtain made a disapproving noise. Ruth went back to the television lounge and fed her baby in the dark, illuminated by the television. As the night went on, the baby started to 
talk to Ruth, saying, 'No,' when she took it off her breast. It was a boy, then a girl, then a tiny strange monkey who had lost a hat or a glove.

A nurse came and told her she needed to go back to her room. It wasn't good for the baby to be up all night watching television. Ruth said the baby was disturbing the other woman in the room. The nurse said she couldn't be afraid of other people, it was her room and she needed to stay there. Ruth went back to her room. The baby cried and the woman said, 'Be quiet,' so Ruth snuck out of the room, out of the ward and walked the baby up and down in the foyer by the outpatient clinic. When she came back the door to the ward was locked. There was a phone by the door, she lifted it to her ear. The nurse told her she couldn't just leave the ward; they had been looking for her, where had she been?

'Can I go home?' Ruth asked.

'If you're asking whether you can discharge yourself,' the nurse on the other end of the phone said, 'we wouldn't advise it, but we couldn't do anything about it if that's what you decided you wanted to do and there are plenty of people who would be happy to have your bed.'

'Can you bring my clothes out?' Ruth asked.

'You can't discharge yourself now, it's late. You have to wait until morning.'

The door made a clicking noise and opened out toward Ruth. She and the baby went back into the ward and sat in the dark in the television room. She watched the baby until the sun came up. It wriggled slowly, like it was struggling to get out of something. It scrunched up its nose and every time it opened its eyes it looked like it had woken up in a bus, or at work, or somewhere it didn't expect to wake up. Ruth held its hand and found a plastic bracelet on its wrist. 'Baby of Ruth Spencer,' she read. It was true - she'd seen the baby come out of her own stomach and it hadn't left her since. The baby stretched and started nuzzling into her, looking for food. 


\section{THE KISS}

ON THE 16TH OF DECEMBER, 2000, the soldiers of Bravo Company woke in Dili, showered, dressed in civilian clothes and made their way to the vehicles that would take them to the plane that would take them home. There was towel-flicking and a shared feeling of excitement and happiness. They had packed the night before and their rifles would travel separately. In Darwin they changed planes and boarded an Air New Zealand flight. They laughed at the safety instructions, ate small bags of roasted peanuts and drank complimentary beer. Several air hostesses declined to give their phone numbers and a few soldiers looked out the windows at the clouds and felt their eyelids drop. The flight home was noisy; there were jokes and horse-play, head-rubbing and play-fighting.

As the plane flew over Canterbury the men became quieter. Some of them shouted out landmarks that became apparent as they continued their descent. From the plane they could see the airport and the large sign saying Christchurch. They couldn't see the large crowd of family and friends waiting in the arrival area, 
but they felt it. On the ground and as the seat-belt sign went off, they felt the weight of people waiting for them. They disembarked, saying thank you to the air hostesses.

Before the doors through to the arrival area there was a duty free shop. The first off the plane stopped at the shop and the others, one by one, five by five, fell in. Recognisable as soldiers from their short haircuts and tidy jeans, they tried on sunglasses and looked at bottles of spirits. The married soldiers smelled perfume and asked the women behind the counter about them. Three soldiers, almost the last off the plane, stood like guests at a party until they saw another soldier looking at a shelf of aftershave. Wyatt, a broad man who wanted to be a chef and was everyone's first pick for touch rugby, joked that even the most expensive aftershave wouldn't help the soldier have sex with anything resembling a woman. The others laughed. They started looking at the aftershave, joking about the names, spraying each other with testers. Lennon wore his glasses. Knight, the third man, called him 'my blind foot soldier' when they were on patrol. Lennon said he was fine unless it was raining or humid, which Wyatt pointed out was all the time in East Timor. Knight said 'A blind assassin - stay in front of me.' The first soldiers stayed as long as possible then began to disperse into the arrival area. The soldiers left in the duty free shop could hear shouts, cheers and screams of joy. They looked toward them as the shop fell silent for a moment.

As they walked through, Wyatt was grabbed by his mother and sisters who covered him with kisses and hugs, whoops, small jumps and claps. Knight was met by several women who called themselves his good friends; they hugged and kissed him, except the ones who were in the army as well, these women stood back, shook his hand, then walked into sports field hugs. They thought this meant more than thrusting their chests forward and wet-kissing his cheek. Knight didn't.

Lennon was the last to come through the double doors, his mother was there waiting. His girlfriend ran to him, grabbed his face in both hands and kissed him on the mouth. She looked odd. He was shocked to see her. He'd forgotten 
about her. He'd seen her name on the letters she sent, called her a couple of times. $\mathrm{He}^{\prime} \mathrm{d}$ mentioned her name or had her name mentioned to him in strip bars but he'd forgotten about her - the her that stood in front of him now, smiling broadly and wiping tears away like something he was sure she'd seen on television. She was something waiting for him - what could be done with her now? He kept his distance. He wasn't frightened of anything but he kept a tentative distance, unsure of what she could tell or smell or sense. He smiled at her carefully from beside his mother. Wyatt and Knight came over, said something about a party in the afternoon and gave him the address and the time. Wyatt was going to have breakfast with his family and Knight said he was going to have sex with one, or more, of the women. They left.

Eventually everyone left. Lennon kept saying, I just need to see so-and-so, and ducking off but eventually everyone had left and he was there with them and said 'Shall we go for some breakfast? I could murder some food.' He would travel with his girlfriend and his mother would come in her own car.

On the way to the restaurant there was a long silence. Lennon put his hand on his girlfriend's thigh and said 'Good to see you.' She glowed and beamed 'Oh Mike.' He didn't need to say anything or touch her again for the rest of the car journey.

They talked at breakfast - caught him up on things. Lennon ate, nodded, looked at his watch and the clock on the wall behind his mother. He paid the bill and met them in the car-park. His mother said goodbye. He thought he would mess around in town until the party but his girlfriend held out her car keys and asked if he wanted to drive. She meant back to her place, to drop his stuff off, and he realised she expected him to stay there. He was going to crash at the party or catch a lift back to barracks but he didn't tell her that. It could still turn out that way, but not if he told her. He hadn't driven for nearly a year. He'd been awake for almost twenty-four hours, traveled hundred of kilometres and she wanted him to 
drive so she could feel like a war-bride. It was easier than fucking and would get him into town - eating and marching, concurrent activity.

To avoid unease he took another, longer shower and dressed in the humid dampness of the bathroom - blind. She offered to take him to the party and he said no, Wyatt was picking him up. She said okay and looked out the window. He told her not to start and she said sorry, it's just that he only just got home. He said just don't fucking start and she said yeah, she wouldn't start, she had stuff to do. She had no money. He could tell. She was listed as a dependant on his record. They'd lived together for a year in the housing area. She'd left while he was in Bougainville for a week. She'd taken lots but left more. She took the cat. Weeks later, when they were back together, it had to be put down after it broke a hip. She got another cat. He offered to look after it when she moved into this place. It disappeared within a week and she didn't say anything about it. He suspected she was saving it up and about a month before he went to East Timor he was right. $\mathrm{He}^{\prime} \mathrm{d}$ wanted to go out for dinner and a movie with someone and she said she didn't think it was appropriate for him to go. He said he was going, don't start, and she said, 'What about the cat?' He took forty dollars from his jean pocket and left it beside the basin for her. She'd put on weight. Shitloads of weight. Every time he went away she put on weight. When he got back she put on more. She looked fat. One thing about Indonesian woman - they weren't fat.

Wyatt arrived fifteen minutes prior to parade with Knight in the back seat, slightly drunk in the arms of one of the women from the airport, she was also quite drunk. Lennon saw his girlfriend see the woman with Knight and as she opened her mouth to say something he said, 'She's a hooker. It's only strippers and hookers at the party.' As he jumped in the front seat his girlfriend told him to text her and she'd meet him in town and something else as Wyatt drove him away from her.

In the car Knight said the woman he was with gave good head. She hit him on the arm and sat slightly taller. Wyatt asked how was brunch and he and Lennon 
laughed, saying, 'Fuuuuck!' and shaking their heads. What is up with them, they asked. It was doing Lennon's head in, he said, and Wyatt agreed it was also doing his head in. Knight said a surf would be good as they passed the beach and Lennon said surfing was a pussy sport and Knight was a pussy. Knight said it was better to be a pussy than pussy-whipped like, for instance, Lennon. Lennon leaned over and slapped him. Knight slapped him back. Lennon told Knight not to make him come over there and turned back to the front of the car. There were people on the golf course, men and women playing golf like it was an ordinary Saturday afternoon. Wyatt pulled into the Mall at Shirley so they could all buy lots of alcohol. Knight bought the woman a lollipop. The mall was full of people Christmas shopping. Tinsel and snow hung off everything. The woman stopped to try on sunglasses and said, 'Buy me some sunglasses, Knight.' Lennon said, 'Buy me some sunglasses, Knight,' and told Knight to sort it out, for Christ's sake. They all had a lot of money. Knight said quietly to Lennon that he, Lennon, didn't understand just how good the head was she gave and handed her a fifty dollar note. The woman kissed Knight on the cheek, took the money and, while the men were in the bottle store, didn't buy sunglasses.

The party was on Bealey Avenue, a long road with tall trees along the middle of it. It was daylight when they arrived. On the front lawn of the row of flats Kimbell was chasing Wyman and Miles was yelling at Davids. Some other soldiers were sitting in the sun drinking. Wyatt, Knight and Lennon nodded at the men on the lawn and Knight, with his arm round the woman, tried to catch Wyman as he ran past. Wyman yelled something like 'pussy' at him, so Knight joined Kimbell in the chase. The woman who was with Knight stood and laughed and opened one of Knight's beers and drank it.

Inside the flat the curtains were drawn and the stereo played loud music. There were soldiers in every room; lying on couches, sitting on the floor - all drinking. The host, Taylor, was in the kitchen with his hand up his girlfriend's skirt. When he saw Lennon and Wyatt arrive he smiled and welcomed them with a slap 
on the back. His girlfriend pulled down her skirt and emptied a bag of chips into a bowl. Taylor led them through to the living room where they were welcomed with a volley of hoots. Someone made room for them on the couch and they sat and drank and no one said much to anyone except quotes from Full Metal Jacket and Terminator. When it finally got dark the lounge was cleared a bit and the strippers arrived. Taylor's girlfriend and the woman with Knight joined in. Lennon was offered several women but said he was home now and everyone said 'pussywhipped' and pretended to be on leashes. Taylor's girlfriend chose one of the strippers and Taylor said for everyone to look after themselves for a couple of hours. Someone shouted more like a couple of minutes and Taylor emptied the bottle he was drinking from and threw it so it hit the wall and exploded.

Around nine, Lennon's cell phone rang. It was his girlfriend. He sighed and let it ring. He turned and asked if Wyatt wanted to go into town. Wyatt said sure. Lennon stood up and went down the hall to find a quiet room. The first one he tried had people in it, so did the second but the third was empty and dark. He closed the door behind him, keeping it dark, and rested his weight on the door. Sudden movement coming toward him startled Lennon. The man, who he couldn't make out, said 'You came.' Hands pulled Lennon's face close and kissed him. The hands held his head, his neck, his jaw, pulling him closer and further into the kiss. Then pulled back and pushed Lennon away. Cold rushed in. Lennon's phone rang green and illuminated but the man was gone. Lennon closed his eyes and felt it all over him, again and again - the stillness of the room. Quiet and alone - it was all he wanted. Someone was calling his name from another room, Wyatt, asking where the fuck he was and had anyone seen Lennon.

Although the rest of the house was only dimly lit, it was blinding. The right thing occurred to Lennon - to run from the room screaming that some faggot tried to kiss him. All eyes were on him, saying Wyatt's looking for you and slapping him, shouting 'pussy-whipped' and saying she could smell him up to no good. Wyatt was with Knight when Lennon found him, on the front lawn holding his cell 
phone to his ear. When he saw them he wiped his mouth with the back of his hand. It took him like falling - the sensation that hung on him pushed deep inside, filling him, trying to escape out every pore. Wyatt raised his eyes, pushed the phone into Lennon's chest and told him to fucking sort it out. It was her. She'd tried his phone and couldn't get through so she'd called the barracks and someone had given her Wyatt's cell number. Lennon looked at the empty sky. He said he'd been trying to call her from a quieter room and she was engaged so he'd stayed there for a bit and tried again and dozed off and way too much. She wanted to meet him in town. She was out with a few of their friends. Did he want to meet at this bar? Wyatt was standing beside him drinking his last beer. Lennon asked if he wanted to go to the bar. Wyatt said sure, yeah. Knight said, 'Don't fucking humour him, he's got to sort that bitch out.' Wyatt said he was out of beer so he needed to go somewhere and Knight could talk - where was his missus? Knight said she wasn't his missus and he told her to go home when he found her and Taylor's missus having sex with about ten guys watching. Wyatt pissed himself laughing. Knight said he would go to the bar, not because he wanted to but to show Wyatt what a fuckwit he was, and that he, Knight, wouldn't be alone for long but Wyatt would be alone forever. Wyatt said he would rather be alone forever than not get invited to his girlfriend's live sex show. Knight said shut up and for fuck's sake hurry up, Lennon, if they were going let's fucking go for Christ's sake.

Lennon got off the phone and handed it back to Wyatt without saying anything. They began to walk away from the party when Wyatt said 'Where's your fucking jacket Lennon?' Lennon had taken it off inside somewhere. As he walked back over the lawn, where several soldiers lay, everything shifted. On patrol, at night, no one slept until it was their turn and then they slept well. During the day, through the strangle of Indonesian bush, each man watched the one directly in front, never needing to look back or to the side. When the militia opened fire they retreated and hid together in the small spaces they found down low and were quiet. He should find the faggot and tear him apart. Davids and Wyman leant on 
either side of the door, beers in hand. They nodded and met his eye. There were soldiers everywhere inside. He had to push past to get to the lounge. They were pushing on him, leaning on him, heavy and drunk. He said sort it out a few times and with every push on him his body swam and the margins where his skin stopped broke like shrapnel wounds. When the shooting stopped several of them were crying with fear. They crawled out of their low places to find Deering missing. Lennon's body was leaking out his skin and the pushing and the leaning was leaking into him. Washing in like a tide and he was getting fuller and fuller and could feel every pore of the skin on his face.

Miller was on his jacket, a topless woman in a g-string was on Miller. Lennon leaned down to pull his jacket out and his cheek grazed the woman's breast. He turned and kissed it. She held his head close to her. Someone grabbed his arm; it was Wyatt come to see where he'd got to. Lennon turned quickly. Wyatt looked him in the eye and said, 'Have you got your jacket?' Lennon looked around to make sure no one else had seen and pulled his jacket out from under Miller. On the way out Lennon's girlfriend called Wyatt's phone again and he told her they were on their way and would be about half an hour. As he hung up he told her to lose his fucking number. Knight met them outside and asked where the fuck Lennon had got to. Wyatt raised his eyes and said let's walk to the bar.

They walked and kicked things and jumped over things and hit things with their heads but none of them were looking for a fight. Lennon's phone rang, he didn't answer it. 'Oh fuck, Lennon, she'll just call me - for fuck's sake.' Lennon said 'All right,' told them to go ahead and pretended to answer his phone. Knight said, 'I'd do her.' Wyatt looked at him like you've got to be joking and Knight said, 'She must be fucking amazing for Lennon to put up with all this shit.' They both laughed and felt grateful.

'Makes you want to go to war,' Wyatt said. Knight laughed and Lennon looked around and said he'd get the drinks. There were dress pants everywhere; men their age with stupid civvie haircuts drinking stupid drinks and chatting up 
ugly hairdressers and receptionists. The doorman had said he didn't want any trouble. Knight said 'Mate, there's only three of us.' The doorman had let them in, repeating he didn't want any trouble. It all operated below them - everything that goes on. Broken shoelaces, lost jobs, car insurance. Not by choice. It was just where they lived - a couple of feet above it all.

It was always going to end up like this. Her on the floor, Lennon's hands around her throat, shaking her, shouting shut up. She would start and then she pushed and pushed him to this. He didn't want to look at her. He threw her head onto the floor, stood up and started collecting his stuff. Lennon's girlfriend got up and begged him to stay. It was night of the living dead. He didn't want to look at her. She grabbed his arm, using all her weight to try and hold him back. He pulled her down the hall and threw her against the wall. She slid down it, crying. He fumbled with the dead lock. She told him the key was in the kitchen if he wanted to go so badly. He went to the kitchen, threw some dishes around and let himself out.

Lennon felt good to be outside in the dark. It was a clear night. The sun would be up in a few hours, until then he would walk around. He'd get some breakfast and call Wyatt for a ride out to barracks. It was what he'd wanted from the start. It was all he ever wanted. He walked past houses and pubs and through a cemetery until he came to the river. He sat beside it and watched it move. The air was still and held his face. As the dark water bit at the shore he ran every man's face through his mind, trying to match jaws with the one that had touched his. He thought of their hands and then their hands holding their rifles. He eliminated some, shivering in the pre-dawn. He could feel the indent of those hands on the back of his neck. The light had fallen on Deering's face. It shouldn't have but after they'd looked and looked, in a place that was previously dull, a light fell on Deering's calm, still face, where he lay alone and quiet. Knight had said 'For fuck's sake' and turned away. Wyatt had vomited, resting his whole body weight on his rifle as he bent over. Out of all of them, Lennon wished it was Deering. He ran 
through every man's torso, their chests. He mixed torsos with faces and hands. Someone's right hand with another's left - Deering's head three feet from the rest of him. Carrying him back to camp, holding his head, his neck, his jaw. He went over it all. Trying to remember every time he had touched or been touched by anyone in Bravo Company.

When Lennon arrived back at Taylor's flat there were still soldiers everywhere, asleep now. He walked through the house, through room after room of sleeping soldiers until he found the room where it happened. It was still empty. He closed the door behind him. The first of the dawn broke through the Venetian blinds as he lay on the bed. He teetered on sleep and felt the weight of everything above him - gravity pushing it all down on him. That faggot was bound to come back and when he did Lennon would kill him. Something wrong until now slipped and was almost right. Everything rose in him as he remembered. In his mind he heard Deering breathe - in and out. He breathed in what was left of it. His phone rang in his pocket and, with the last of his energy, he threw it against the wall and slept well. 


\section{BELIEVE IN JIM JONES}

\section{IT WOULD HAVE BEEN MY IDEA. I would have gone to}

my husband and my mother and my father and everyone I knew and said, 'You have to hear this preacher from Lynn.' I would have said things like, 'Blacks and whites worship together,' and 'No one should be poor,' and 'Come to People's Temple. Come see him. You have to see the Reverend Jim Jones.' My husband would have come and some of my friends and my mother but my father wouldn't. My father would never have come to People's Temple. If my mother told him we were going to Ukiah he would have said, 'Go.' And later, 'I sort of always knew I'd never see them again.'

I would have held my hands high and soaked it all up - God through the baptism of the Holy Spirit. The words Pentecostal and Charismatic spinning in my thoughts, my every conversation and all the deeds I did. The special effects: glossolalia, prophesying, healing. All hail Jesus and the socialism of People's Temple. 
Jim Jones said, 'I represent divine principle, total equality, a society where people own all things in common. Where there is no rich and poor. Where there are no races. Wherever there is people struggling for justice and righteousness, there I am. And there I am involved.' Jim Jones placed an advertisement in the Indianapolis Star saying he had some monkeys to sell. People came and bought his monkeys and heard about People's Temple. He said, 'Jesus Christ had the most revolutionary teachings to be said, in the sense that he said to feed the hungry, clothe the naked, take in the stranger, administer to those who are widows and afflicted in their suffering. And we feel that no one really tried Christianity too effectively in the Judeo-Christian tradition.' I would have to agree with the Reverend Jim Jones.

I would've liked the talk of utopia and the singing. If I was sick or if my husband was sick or my mother or my baby I would have liked the healing. I would've liked the healing the best. When we were well I would have baked something for the trip to Redwood Valley. We would have packed our car and locked our door and picked up my mother and we would have left for Redwood Valley. When my father said, 'Go,' and I kissed him goodbye I'd have thought I would see him again - in utopia - soon. I would have been hopeful and I would have spread that hope. Any time my husband was quiet or thoughtful on the trip I would have said, 'You got nothing to lose. Who else is going to stand and look you in the face and say "Come and I'll give you a job. Come and I'll give you a home. Come and I'll give you a bed?" You say, "But I can't even get a mortgage for a house." "Go and leave your inability to enter the housing market behind." Who else will tell you that? Who'll tell you, "I'll put you on that bus tomorrow"?' My husband would have squeezed my knee as we drove along and said, 'You're right. We're doing the right thing.' My mother, from the back seat, would say, 'Amen.'

When our pastor said, 'Don't talk,' I wouldn't have talked. I wouldn't have turned anyone else in for talking but I would not have talked myself. I know that about myself. I'm a coward but maybe People's Temple would have healed me of 
that. Maybe I would be reborn heroic. I would have gone to Guyana. Even though I don't know, even now, where Guyana is, I would have gone. Even if I suspected I was being none too bright. I hate admitting I'm wrong. When they started poisoning the babies I would have held my baby and I would have held my dying husband and I would have said something like, 'I got us into this, I'll get us out of it,' and then I would have laid down, most likely, and pretended to be dead and not been. When it was quiet I would have stood up and looked around. I would have shaken my head and been alone in the world again - without a family and without a church. I would have tried not to but I would have looked, straight away, for the next thing. I would have thought Jonestown was perfect without Jim Jones. It was heaven on earth. I would wander and stumble in the humid jungle waiting, looking around for the next thing - someone to lead me. 


\section{FUNNY TOO}

\section{FOUR OF US ARE SITTING IN THE SUN, in a garden}

bar. There's Digby and me, Seamus and Rose and their twins. Digby, Seamus and I watch the kids running up and down the stairs. Rose is reading the Sunday paper.

Seamus tells a story. He says when he did music at school they played bells. Seamus's school spent a fortune on a set of hand-bells and the music class played Goodnight Kiwi on them at assemblies and old people's homes.

'Hine e Hine,' Rose says it without looking up from the paper.

Seamus says, 'Eh?'

'It's called Hine e Hine.' She still doesn't look up; she licks her finger and turns the large newspaper page. 'The Goodnight Kiwi song.'

Seamus says none of them wanted to play the bells, the whole class just wanted to sit round with guitars and learn Sweet Child of Mine by Guns 'n' Roses. 
'I've seen photos,' Rose says. I can't work out how she's reading and listening at the same time but she looks like she is. 'He cheated in his grade two theory exam as well. He wrote on his pencil case, in code.'

'It probably took longer to work out the code and remember what it stood for than it would have to study for the exam,' Seamus says.

'Is that what you're going to tell Mack and Sam,' Digby says, nodding toward the twins. They've just started school. We all laugh.

Rose says, 'How do you convince a jury in Christchurch that a police cadet raped a drug-addicted prostitute he'd already paid for sex?' It sounds like the setup for a joke. It's not.

'Um, you don't?' Seamus says, looking at us and shrugging his shoulders.

Rose flicks the paper out straight again, 'He said being a police officer was his life-long dream. He started Police College when he was thirty-one.' Mack comes over and takes a sip of water from a glass on the table. 'That's a long time to wait to fulfil a life-long dream.'

'Mack!' Seamus says, standing up. Mack is pouring the glass of water over Sam's shoes.

Rose looks up from the paper and says, 'Isn't it?' to us.

Digby and I walk home in the sun. On the way I'm laughing every now and then. Out loud I go, 'Bing. BingBingBing. Bing, Bing, Bing, Bing - Bing,' ringing a pretend bell on one of the 'bings' and waiting in anticipation through the others. It wears thin and I have to run to catch up with Digby. I think about asking him what his life-long dream is to make up for annoying him with the bell thing, but he says, 'Mack and Sam are funny, eh?' And I say, 'But I'm funny too, eh?' 


\section{ONE OF YOUR SKIES TODAY}

\section{THEY SAY IT STARTED IN YOUR LUNGS. That's}

what your nephew tells me. Someone else tells me they can't tell where it started, just that it's everywhere now.

Your sister Anne asks what they're going to do. They say, realistically, you're not going to get better. She holds your hand. It's in your brain, that's why it hurts in your head. They've given you morphine and that's why it doesn't hurt now. They say you're not leaving the hospital. You know they mean alive. Anne took you to Accident and Emergency three weeks ago and they said it was viral. Your son, Benny, called Anne a week later saying he'd found you thrashing around. She came to stay. A couple of days ago you said you felt like fish. Anne cooked you some fish. You said you felt like curry sauce on your fish. She went out and bought curry sauce. When she got back you said you didn't feel like it any more. This all comes out. They say you have options. You hear the word 'titrated' 
and think it sounds like bells. Your sister says it's for the best. You agree, sign some papers and they put in a drip.

You feel like a cigarette. When they ask if they can get you anything they don't mean cigarettes. By the afternoon, you can't move any more. Anne says she's just ducking out for a minute - for a cigarette. You try to ask her to get some patches while she's out but you can't move any more. You tried to give up once. You ended up wearing the patches and smoking at the same time and going to the doctor who said you were passing out because your heart was beating too fast. You've given up now.

Other people in the ward have their lunch. You've probably had your last lunch. The doctor explains to your sister that you're unconscious now and will just drift off. This is not a technical term. You're not thinking, I wish I spent more time working, and other clichés. You remember eating fish your son caught, and cockles you collected and opened over a fire by dark water alive with phosphorescence. It seems fitting but not altogether yours. You haven't seen your oldest son in a couple of months, maybe a year. Anne tells you she called him, he'll be here in a couple of days. So this drifting away, you think and listen hard to see if anyone is mentioning time. You hurt. One at a time your insides expand, catch fire and start crawling around the dull ache that's everywhere. The pain starts to make noise and smell like sand. It's loud in your ears and the air around your face is warm and damp with it. You feel yourself drifting away from it and panic. Your sister's face may be the last one you see. You haven't seen yourself for days.

Anne's son says hello. You almost forget you can't move. Your sister's a mess. She's trying to be something her voice isn't. She asks her son to go to your house and get some of your spiritual books and find out where the hell Benny is. She tells him to stay here for a minute while she ducks out - for a cigarette. Her son sits down, then stands up, then tucks you in, then un-tucks you, then says nothing. The others wouldn't play with him. When it was his turn the other kids said they didn't want to play any more. He's the youngest, the tallest. Your sons 
look like small men next to him and they're not. He walks to the window, opens the curtains a bit and says 'What about this weather?' and 'The sky looks nice, Aunty Jo. It's one of your skies today.' You and he dig a hole and the warm water comes up. It gets hotter the closer you get to the sea, you tell him. The other kids are off somewhere with Anne. You say the hole is big enough but he keeps digging so you keep digging. You both jump in the sea to get cold first. The others come back and he hits his sister and your sons for no reason and says it was their fault. Anne comes back, tells him not to forget your books and to get Benny to call her when he finds him. She's got her mobile. Then it's you and her again like it has been for the last couple of months, since your mother died - old and confused.

You can't feel your eternal spirit self, if anyone's interested - hello? You can't feel your eternal spirit self. So don't start with don't forget the books. Forget the books. Forget Sharkti Gawain, Kahil Gibran, and Conversations with God. Find Benny and forget the books. Look in the middle of the road. That's where he was the other time he went missing, when he was four. In the middle of Panmure Drive, looking both ways like a dog off its lead. Your nephew should look there. That was the last place you looked. You checked all the closets. You checked under the car. You asked your oldest son over and over again; promising each time he wasn't going to get in trouble, you just needed to know. You checked under bushes, in the garage, in the boot of the car, next door and upstairs. Then you decided to go for a walk and shout his name for a couple of blocks, 'Benny!' You bundled up your older son and when you got to the top of the driveway there he was, standing in the middle of peak hour traffic, counting. He looked worried but he said he wasn't. Your nephew should check there. That's where Benny went to think.

You could find him. If you had one more hour you could find him. Haven't you done enough for one more hour? You nursed your husband to death, you put your oldest son through flight school, and you gave regularly to charity. Surely that's enough for another hour. Anytime now would be good. You could rise and 
walk again, leave this hospital, leave this bed and find Benny. You just need an hour. It's not much to ask after everything you've done; an hour to say 'goodbye' and 'stop using drugs'. Why didn't you say that? In all the counseling and treatments, why did you say 'I'm here,' and 'Whatever you need'? Why didn't you say 'Stop using drugs!' really loudly? Who would say that now? You need one more hour to tell someone to tell Benny to stop using drugs - loudly. Surely you've done enough for one more hour and anytime would be good. Anytime soon would be fine. Anytime now would be good, or when your nephew brings him back. He should check the middle of the road, or the couch, or his bedroom where he keeps the curtains drawn and the stereo up - where he went to think ever since he came out of the catatonic state he arrived home in from Hawaii. Lots of sun in Hawaii, people want to get away from the main island, though. That's the mistake people make. People only visit the main island but they really needed to get away from the mainland and go to the outer islands: Maui and that. Maui's nice. It's a very spiritual place. Where are your books? What happens now and where the hell is your eternal spirit self? Anytime now would be good.

Sleeping feels more like waking now. You're padding round the ward in your bare feet, looking for a cup of tea. Waiting for the others to bring your clothes and take you home. You can't find your handbag, so you can't find your cigarettes, so you can't have a smoke. A nurse offers you a cigarette and you smoke it under a No Smoking sign on the mezzanine that looks out on the indoor garden. They have an indoor garden and you start to lift off the ground. Your feet lift off, toes last, and you take one more drag and throw the cigarette away as you fly over the indoor garden and leave it all behind and then there's a bang and you wake into darkness. More darkness and the pain's back and you scream and yell. Does no one know how much pain you're in and then there is no pain, as fast as that. You fly, like gliding, not swimming. You swoop and dive. The leaves from the trees flick when you pass them too close. You find your handbag in a high branch. You find your 
jeans and some underwear you haven't worn yet - you got them a month or so ago and they're still in their packaging. There's a little plastic pin holding the price tag on. You sit in the tree and pull the price tag and the pin stays so you use your teeth to break the pin, kissing the cotton, leaving lipstick on it. You can't remember putting on lipstick and you need a scarf because it was cold when you left. When you see a shoe you like you buy two pairs - one in black and one in brown. If you had your handbag you could take yourself home, you could get takeaways on the way home. It's nice to be hungry. You swing your feet and wait for your sister to bring the car round.

There are, it sounds like, ten maybe fifteen people in your room. Your oldest son is there, he sounds grown up and he's not crying. He says, 'Yeah, I'm staying here.' Anne's here and her son and I'm here. There are some people telling your sister you will be free soon and does she mind if they pray? Anne says, 'Sure,' but you say 'Fuck off. Don't you dare pray you self-righteous, self-serving freaks.' You won't help them get more time. You've done enough for one more hour. You've done more than them. And they say 'God' and anytime now would be good. You don't see your sister leave the room and complain about the praying people and cry and call them bad names. When I find her she stops talking quickly and wipes her face and says she's popping out - for a cigarette. When you and I are alone I tell you you're going on an adventure. I have no idea what to say. It's the only time I talk to you. I talk to both your sons and your nephew and try not to cry because it isn't worth anything now. I didn't want to come. People say 'What's it all about?' and 'It's sad,' and 'She looks so peaceful.' Your sister keeps putting lipstick on you and people take turns putting water in your mouth with a sponge on a stick. No one else wants to leave at any time. I leave any time I can to eat, to laugh with a friend who lives around the corner. I think about going to the museum to see the mammoth Anne used to call a flea-bitten old thing. On Sunday I leave and go home in an aeroplane. Anne's husband said there was no real point in coming. 
You notice I' $m$ gone and then forget. You change your mind about it being for the best. You want one more hour. You try to tell your sister. It's like a bad dream, so you try to sleep. It's getting easier now. People keep you up sometimes, telling you things, like you're going on an adventure. Your mother comes and knits but it doesn't make you feel calm. You would kill someone if it meant you could have one more hour. You would kill a child, a baby, an old person someone else's baby - your own baby. You've been good enough for one more hour. If you killed someone, though, you'd want more than an hour, especially if it was Benny, you'd want - half again. That seems fair. Or you could go back. You could go back, go to the doctor and find out you were sick and have treatment. Without this, that would be just as bad. That seems fair. You start to make lists about what you would be willing to do. You would kill those praying people over and over. You have money. But you don't really care. It gets boring.

In a dream, maybe, you walk around the wards. You can't fly any more. You see children, sick and dying, and think you're Jesus. You place your hand on them and nothing happens. Your children bled a lot. Not more than anyone else probably, more likely the same. Your oldest son came from the Bahamas. He has a kite surfing business there. The dying children are just lying dying so you walk to the magazine store. You never get time to read any more. Eternity's a long time, standing where you are now, flicking through magazines in your mind, in a bed.

Your sister opens the curtains and says, 'Good morning sweet-heart.' It feels like a very important job you're doing; a factory job in a factory that makes important things for people. Time is fast. You're sad. You have no idea what you want. It's empty and hollow and nothing happens, over and over again. People fall into routine: meals, reading, visitors bringing food and soap. The room smells sick with flowers. You're sorry. Everyone said Benny might not live long. You wish everyone you loved was dead. Nothing anyone says is helpful. Dead people come and go - some of the children from down the hall, and none of it helps. The truth falls around you a little at a time, like deep water, but falling. 
I call your sister most days and she holds the phone up to you and I have nothing to say except no. In my dreams you dream big, hopeful dreams and there is no romance or spiritual depth in any of it. No one comes to anything that helps them. Everything you had and lost and kept safe is laid waste. I look for light and any dullness amounts to nothing. There is no useful problem, just days and days of end.

You die eventually and while I'm at work. Anne calls and says it's over. The woman who works opposite me is eating tuna from a can, a courier arrives and picks up a parcel for a company in town. My boss talks on the phone with his feet on his desk, looking out the window as a mist falls on the hills. 


\section{DROWNING-BABY PRAYER}

IT RAINS - rains and rains and rains. We sit in uncomfortable chairs in a Quaker meeting room walled in Quaker pamphlets. We sit in expectant silence.

Over the rain and the silence comes the sound of construction - a band-saw and an angle grinder. It's really raining. Things are coming out of the drains. I nearly run over a rat and someone tells me they can't stop using methamphetamine. I tell them, I think that's the idea with methamphetamine. It could be a palm sander. I joke, he's building an ark. I say it a couple of times in my head until it's good enough to say out loud then I say it out loud and add 'I hope so,' because we' re all convinced friends here.

On the way home in the car - before I see the rat, the giant rat, the rat that could have been a cat if it wanted - we talk about Catholicism. How it has everything we're looking for: incense, sacrament, magic tricks.

'I think I could be happy in all that show,' Nell says. We all do.

'When I was young,' I say, 'I watched The Nun's Story.' 
Honey says, 'Was that Julie Andrews?' and Nell and I say, 'Nooo - that's The Sound of Music.'

'They cut her hair off and she married Jesus,' I say. 'It was a great haircut.'

Nell says, 'She's wearing nail polish.'

I say, 'Nuns don't wear nail polish.'

And Nell says, 'I know. But when she's taking off her wedding ring at the end she's wearing nail polish.'

We chatter like this after the Quaker meetings, like we're on fire with making noise.

'Catholics can do anything,' I say, 'like superman.' I try to remember the prayer that saves a child from drowning. I was given it on one side of a small piece of cardboard with a prayer for getting people out of purgatory on the other.

I have no idea where the rat thinks it's going. It just runs out of the drain and onto the street. Then I nearly run it over. Then it runs back toward the drain. When I get home it's still raining. No more water is going down the drains; water's rushing over the top of them and trying to force more down them at the same time. It's like a metaphor for some sort of Freudian thing that explains why people can't stop being evil.

The next day it's still raining. My father rings and says he's lost a gate and two palings from the fence. I ask him what a band-saw is and he tells me what I probably mean is a bench-saw and I say, 'No, I think I want a band-saw.' I find the drowning-baby prayer folded to a tiny nub and squashed into a book about the Dali Lama like it's waiting to hatch; evidence that at one point I believed it would hatch. Some of the hill across the road falls down and a fire engine comes. I watch the light turn - red in all the grey and rain. 


\section{OVER AGAIN}

IT W AS FRIDAY NIGHT. The city was busy and the bar was three deep. Lucy had been sitting at an outside table with Mark and Jane for most of the afternoon. Cyrus saw her on his way into the bar. He ordered a drink, came over, lit a cigarette and asked if he could join them. Lucy pushed her hair behind her ear. They drank some more. Talked about what brought Cyrus back from Melbourne and drank some more.

'How's Kate?' said Jane.

'Kate's great,' Cyrus smiled.

'We should get some dinner,' said Mark, 'you coming to get something to eat, Lucy?'

Lucy smiled and frowned at the same time, like she'd already eaten something she shouldn't have, and shook her head.

Mark and Jane left to get something to eat, shaking their heads.

'How much money do you have?' Cyrus said. 


\section{Lucy shrugged.}

He said a friend of his was working at a bar and they could get more to drink. Lucy said, 'Sure.' They leaned on each other a little as they walked along the newly dark streets full of people shopping and going home. At the bar she paid for more drinks and they drank some more and shouted humid indignation in each other's ears. Cyrus said he had gin at his place and she said she had her car. Lucy drove in silence and at fifty-five, changing down at every corner, coming to a complete stop at every intersection.

In his bedroom she said she'd drunk enough, thinking about driving home. She asked for a glass of water. He handed her a glass of gin and she said thanks. Her jaws were fluid and he was talking and playing music. It got later and she couldn't walk. Lucy thought, it's okay I don't need to walk to drive, and, I can't stay here, and, don't stay here. Cyrus said, 'You could stay here.' Lucy said she needed to go to the bathroom. She climbed out a window and drove home, squinting and swearing and keeping all the street lights on one side.

The next day Lucy worked and every time the phone rang her stomach would lift and fall. Cyrus had her number - he had all her numbers. She left one client twice to throw up. One of the other nail technicians sent a trainee to see where she was. When the trainee knocked on the toilet door Lucy slid twenty dollars under it and told her to buy a small bottle of vodka, quickly. The afternoon went a lot quicker than the morning. One client offered her a breath mint and the rest fell into a parade of hands on towels. Hands attached to droning, underwater voices floating over her as she filed and stuck and painted in a cloud of acrylic. Her head swam for shore a little with every pull on her water bottle. She nodded and smiled and said not much. The last client left at half past five and Lucy stood with the trainee watching the till cash up. They drank the wine that was there for clients out of coffee mugs, swung in their chairs and talked about tonight. Lucy looked at the 
phone. As they pulled down the roller grill and locked it the trainee said she should come out but Lucy said no, she was off for a quiet night.

On the way home Lucy stopped at a supermarket and bought a lot of beer. The check-out person said 'Quiet night at home?' She nodded and said 'Uh-huh.' She sat in her room and drank beer. Her flatmates came home, popped their heads around her door and left again. Two of them played some sort of robot war game up and down the hallway with boxes on their heads and she laughed and said she needed to read some books. She thought she fell asleep with an ancient history textbook on her face.

Lucy woke up driving in silence and at fifty-five. There was a number written on her left hand in red ballpoint pen. The clock in her car said three thirty and her hand said 4. Cyrus must have rung. It was dark and probably Sunday morning. She was heading for town with the street lights on one side. If she closed an eye she could probably make it.

She parked her car on a back street and looked around. There was half a bottle of whiskey in her handbag which was on the seat beside her. Lucy drank some more, opened the door and got out. Even with one eye shut the key couldn't find the lock, so she left it and wove her way toward the bar. She went upstairs and knocked on the closed door. No one answered. She knocked again and shouted and leaned on the door until someone opened it. It was dark and loud and full of people.

The bartender said 'Lucy! Thank God. I nearly go out of business every time you stop drinking,' and she laughed and he said, 'No. Really.' He leaned over the bar, touched her chin and said, 'Lucy. Come on? How about it?' She leaned back, pointed at him and looked around the room.

While Lucy looked one way a tap came from the other and Kate shouted 'Thanks for coming.' Cyrus was beside Kate, in her arms. Arm in arm they stood 
there, in front of Lucy now that she'd turned round. He lifted his glass to her. 'Shall we discuss this outside?' said Kate. Lucy nodded draining her glass.

They stood, the three of them, outside. Cyrus lit a cigarette and took a step out of Kate's way. Lucy lit a cigarette and Kate started. Basically, it was just everything she'd said on the phone. Lucy wasn't sure if she should run or nod politely. She looked at Cyrus for any indicators and at Kate, talking really fast, and nothing - something about her and something about him and something about Kate - and Melbourne, Cyrus working something out in Melbourne. The street fell away a bit from under her.

Could Lucy just see her way clear to do that? Kate stopped talking. No one was talking.

'Well, yeah,' said Lucy, 'of course.'

Kate had tears in her eyes, 'I wouldn't ask otherwise.'

'Yeah, sure, I totally understand.'

'I just think,' said Kate, 'We've got a chance this way. Cyrus and I.'

'Uh-huh,' said Lucy.

Kate hugged her, 'Thank you, Lucy. I forgive you totally and set you free.'

Cyrus was smiling and not trying to hide it. Lucy could see it but Kate couldn't.

For a moment Lucy saw how it would all turn out - in a month's time or a week's or tomorrow. Kate saying, 'You promised.' Lucy pretending she knew what that meant. Cyrus laughing behind Kate's back. Kate saying again, 'You need help, Lucy.' But this time Lucy punches her and as Kate falls to the ground strikes Cyrus across the face with something heavy and says, 'You can wipe that smile off too.'

Lucy woke up. Bright sunlight was cutting through a chink in the curtains - not her curtains. 'Fuck,' she said. She rolled onto her back - not her ceiling. 'Fuck,' she said more quietly. Cyrus slept. Kate wasn't there. It was fantastic - Lucy's life like God had run out of things to happen to her and the same thing was happening 
over and over again and He was getting His inspiration from every stupid thing ever said about infidelity. Hopefully it was Sunday, but running it through her head, the robot game, the conversation with Kate, there was no way it was Sunday morning. It must be Monday, she needed to get to work. She got out of the bed and started collecting her clothes. Cyrus stirred and said, 'Where are you going?' without opening his eyes or lifting his head off the pillow. She didn't reply. Cyrus sat up and watched Lucy shake her head as she untangled her underwear and struggled to put them on.

'Come back to bed, Lucy. It's early.'

'I have to go to work.'

'Lucy it's Wednesday.'

Lucy stopped dressing for a split second then started again, hoping Cyrus didn't see her stop.

'Lucy, come back to bed.'

'Where's Kate?'

'Kate's dead.'

Lucy looked at Cyrus for the first time.

Cyrus ran his hand through his hair and looked away from Lucy, 'Lucy,' he said sternly and then started laughing. 'Fuck, okay, she's not dead. I wish she was dead - but she'll be at work by now, and she'll be there all day. Lucy, come back to bed.'

Lucy said, 'Fuck,' again under her breath. She pulled her t-shirt over her head and started looking for her skirt - Wednesday. It wasn't like she couldn't remember anything since the conversation on the street, it was just what she could remember felt like all part of one day, or an hour. It was an ordering problem not a loss problem. She picked her keys up off the floor.

'Your car's not here,' Cyrus was sitting against the wall behind the head of the bed. 'You might as well come back to bed. I carried you here over my shoulder. I went to your house and stole you from your bed while you were sleeping. You 
had nothing to do with it. I took complete advantage of you. Let me make you breakfast.'

They would have fired her by now. They'd probably fired her and hired someone to take her place if it was Wednesday. She put on her skirt. Cyrus was a prick, it was probably Sunday. Kate was probably on her way to take him out to brunch. Lucy couldn't find her shoes. She looked around the room.

'I told her not to call you,' said Cyrus. 'No, I begged her not to call you. I'm sorry you got dragged into it.'

Cyrus was a prick.

'It's not like she owns us,' Cyrus said, 'we're nothing to do with her.'

She couldn't find her shoes.

'Where are my shoes?' Lucy said.

'You weren't wearing them when you got here.'

She looked at her feet. She'd walked to his house in bare feet. It wasn't his fault and it wasn't Kate's fault. It was her fault. It was the drinking. Someone who could help had written a phone number on the back of an EFTPOS receipt and handed it to her last winter in the lobby of the district court. The receipt was in the pocket of her warm jacket which was hanging on the back of the chair in her bedroom.

'Lucy, come back to bed.' Lucy looked from her feet to Cyrus. 'If you don't leave you won't have to keep coming back.' Nothing could help her. 'Lucy. Come on. She won't be back for hours.'

She picked up her sweatshirt from under the bed. She could call in sick. If it was Monday, she could call when she got home and say she was sick. It wasn't Wednesday. She was due some good luck. In the whole economy of it she really was due some good luck. Her car was probably outside parked on the street with her shoes in it and it was Sunday, she could sleep the rest of the day and later on have a couple of wines with Jane and laugh about it. Kate wouldn't find out and the next she would hear from either of them would be a wedding invitation. 
Lucy put her sunglasses on, Jesus Christ himself only knew why the fuck she had sunglasses and no shoes but she put them on like having them there was part of her plan from the beginning. Cyrus went to say something and she raised her hand to stop him. She looked around the room one last time for something, anything; there was nothing to say because everything there was to say had been said and promised and broken and said again. She felt bad and a fool and like this would go on for ever and ever. 


\section{CHRISTCHURCH}

WE DRIVE INTO TOWN and I say ‘I hate this city' - over and over and with increasing venom. Everything I see I remember another reason to hate it. When we get to the car-park we see some people I don't like the look of and that's it; their tiny heads, their red necks. I say, 'It's so cold here no one leaves their family home to breed,' and you sigh and I get the message and finish by saying, 'I lived here for five years and that was four and half years too long.' We find a park on the third floor. There are 150 parks left in the building and it costs $\$ 1.10$ for every half hour and you say, 'Does that change your mind?' and I say 'Nah.' We get the push-chair out of the boot. I have cold feet. It's been years since I've had cold feet. You say your legs are cold. I put the baby's jacket on over the top of the push-chair straps. She can't move so I have to take it off and put it on all over again. As we walk to the lift I look at the hills stretched out to breaking and I say, 'Hard to beat those hills though.' You look out over them and say, 'Yeah - the sky goes 
on forever.' You've hit the nail on the head - the birds don't disappear here. You can watch them all the way to the Alps. Washing takes all day to dry if it doesn't freeze solid on the line. People stay here and the river runs beside them staying.

We see women getting out of European cars wearing fur and Italian boots. It's like someone's set it up just for me to hate and I say, 'Told you so.' You laugh at me. I say, 'What?' You say, 'Just you.' It feels like that here. I try to point it out the rich and white. 'Where are the brown people?' I say and you point to someone and I say, 'What about the Chinese people? Huh? Huh?' You laugh again and it's still just me. The baby's kicking off her boots - over and over. I end up putting them on the handles of the push-chair. Nothing's changed. People are dead and they've been replaced by more and more people just like them. It's like a video game based on a zombie film.

We have lunch at a cafe and they serve us a huge pile of mashed potatoes and mushrooms. You look at it and say, 'It's not a meal you'd cook yourself.' They put whipped cream in cups of filtered coffee and call it a Vienna. The baby eats last night's dinner. She sneaks up on a businessman in a suit and tries to steal his ID card which is on a retractable cord. It retracts. I say sorry and he says, 'Do you want to work at Telecom?' He's talking to the baby. I say I am sure she would work hard and he looks at me like I'm trying to find her a job. I remind him he brought it up. He smiles. The baby walks away and finds an expensive fur coat on the back of a chair. She thinks it's alive which it was once. 'Like everything else in this stinking city, I say to her - she pretends not to understand. 


\section{WHEN YOU'RE SICK}

\section{SHE LIKED TO IMAGINE HERSELF PLACES. A}

small coastal cottage on the way out to the albatross colony, perhaps Otakou, with the fire going and some soup on the stove and people on their way, or perhaps already there - staying over. People visited her wherever she imagined she was. Unexpected people - Henry James, her aunt, The Tudors - mostly dead people and ones she wanted to have sex with, or had stopped having sex with after things went cold, usually through her own fault.

Or Portland, Portland on a spring day with snow still on Mount Hood - the clearing. She made new friends in Portland. Portland was alive with possibilities, jobs she had never heard of, halls full of gluten-free, low-GI food. She would see the world from a different angle in Portland, go to some sort of department store and buy fair-trade sneakers made entirely from old tyres.

On Friday she went to a gallery opening, the launch of a video installation. She looked around and thought, 'This could be Portland.' She looked and tried not 
to listen and soaked it all in, the feeling of being in Portland in her new sneakers. Michael said, 'Sally - you look well.' She wanted to shout 'Portland, Portland, Portland - they call it the clearing don't you know?' As she walked home she imagined her feet on Portland footpaths going past Ankeny, Burnside, Davis and Flanders until she lost herself in the chatter of it all - the Willamette and Columbia rushing by, or perhaps quietly, hardly even moving. She wasn't sure what rivers that size did.

On Saturday she went to the acupuncturist. The acupuncturist said, 'Honey, you don't want to go to Portland when you're sick - bad energy in Portland.' She showed Sally a book that explained why she had eleven needles in each of her ankles and why she needed to surround herself in positive light. The acupuncturist gave her an envelope with a postcard in it and said, 'This is for you to think about.' It was a postcard of Claremont - the city of trees. She imagined herself underwater - breathing on a bed made of trees. Everything was exactly the right temperature. When she moved her arm, or her head, or pushed her hair behind her ears, the whole ocean - all of it - moved to adjust things so she stayed the exact right temperature, completely comfortable. Every part of her supported and held by the perfectly temperate waters. There were no fish but the people who visited could breathe there like her. She left the postcard, back in its envelope, for the next person to think about.

On Sunday she breaks the surface of the underwater in Landmannalaugar, the Northern Lights spread out above her. She leans back and lets them take her breath away. 'It's beautiful,' Michael says.

'It's ridiculous how beautiful it is,' she says. Iceland had never occurred to her. 


\section{HAD NOTHING TO DO WITH IT}

\section{THERE'S TWO TIMES I DON'T HELP JACK. The}

second is on a Saturday at about five-thirty, some part of July - the end of July. So the evening is clear under a cover of cloud. It's winter. I'm walking home. When I turn the corner I see Jack spinning around, looking at the sky, smiling like a fool. His eyes are just whites; his pupils have rolled that far back. Jack is spinning and stumbling onto the road and making noises like an animal. His friends are across at the gallery, watching as if they don't know him. One of them, a guy who likes Bukowski, makes a big arc around Jack as he comes out of the superette carrying a plastic bag full of beer. I cross the road. I do nothing and cross the road. Nothing except look back a lot and think, 'Those fuckers at the gallery should do something to help Jack.'

Then I lie about it. I go to a community meeting with people who want to stop other people drinking in public. I want to make a point about how we should feel grateful we're not on the street drinking, because drinking on the streets is a 
disease, like cancer, and we wouldn't throw people off the streets who had cancer. You wouldn't arrest them, anyway. I say, 'What have you done lately for people who drink on the streets?' Then it starts, I say, 'I'm grateful.' That's what I say, 'I'm so grateful I'm not Jack. When I saw Jack last week I stopped and said, "Are you all right Jack?" and he just smiled in a silly way,' and I get on some kind of lying roll and continue, 'and when I saw his so-called friends across the road, I rushed over and said, "Is Jack all right?" and they said, "Looks all right" and shrugged.' It makes me look good and them look bad and Jack look like someone everyone should feel sorry for. Any point I make with the lie is lost after the next couple of people speak.

Later, my friend Anton says, 'I saw Jack the other day.' He tells me Jack's collecting squashed bottle caps from the street for his next exhibition. He has this crazy long stick thing with a magnet on the end. He has to collect 348 times 6 bottle caps to make a sculpture for the foyer of an advertising agency who are giving him the money for the sculpture. 'That's a lot,' I say. Anton says, 'He must be making a cube.' He says Jack told him the best place to get squashed bottle caps is in the carpark of the wholesaler's. I imagine people buying bottles of beer and opening them in the car-park like they're in a commercial for beer. We see one of the guys from the park buying beer at the superette. He pays fifteen dollars for six bottles of beer. 'That's more than two dollars a bottle,' I say to Anton, 'he should go to the wholesaler's.' Anton says, 'Yeah, and that would help Jack out as well.'

The first time I didn't help Jack was about two months before the second time I didn't help him. It was cold - the first cut of winter or something romantic like that. Jack was walking one way and I was walking the other and I said, ' $\mathrm{Hi}$ Jack,' and he said, 'Hi.' We talked for a minute about how there was no wind to blow away the cold, how it was hanging like something heavy. Jack said he'd better get going because he didn't have bus fare, so he had to walk all the way to his studio in Miramar. That's a long way, and I said, 'I wish I could help you Jack.' I thought about going over to the cash machine and getting him twenty dollars but 
I wasn't sure I had twenty dollars to give him. I did, I had plenty of money. He said, 'No worries,' and I said, 'Next time,' and we said good-bye. As I walked away I put my hand in my pocket and there was five dollars in it. Five dollars was the bus fare and then some. I didn't turn around and I didn't shout, 'Hey, Jack wait up, Jack!' I walked home and that five dollars sat on my bench for ages, because I had plenty of money. I told someone I felt bad about not helping Jack and they said, 'He'd just spend it on drugs,' or 'He has money for drugs,' or something like that.

One day, when Jack is famous, when he finishes the sculpture for the agency and he's famous, I won't be able to say I helped Jack. I'll just have to say I knew him. I might have to say, 'I had a chance to help him, two chances, and I didn't, so he's not famous because of me. I had nothing to do with it.' 


\section{DAIRYLAND}

\section{A DAY OUT, THAT'S WHAT THEY WOULD}

HA VE and it would be fun. They would go out. No one would complain. No, he wasn't having a bar of it. They were having a day out, as a family. They were going to Dairyland like they used to when you girls were young and your mother was still a size fourteen.

The girls said, 'Dairyland?' and 'You've got to be fucking kidding.' And their mother threw them a look like, don't even start with we must be kidding, your father is taking us to Dairyland and we're going and we're going to enjoy it. That's the look she gave and she thought, communication is the key to turning this around.

The girls were in the back seat and their father was singing in the front seat and every now and then stopping to say, remember this, Mary? Remember that, Mary? And their mother nodded and smiled and then their father would say, 'Do 
you girls remember that? Iris? Lily? Daphne? Do you remember that?' The girls said 'Christ! Kill us now. Mother-fucking Dairyland,' but under their breath this time so as not to get a look.

Their mother crocheted in Spring Green as they drove along the coast and the girls looked up through their fringes and wished they were dead. Their father said, 'This will be fun,' and 'We can really turn this around,' and the girls said 'Yeah, it'll be fun like having your tongue cut out with a pair of really blunt, baby finger-nail cutting scissors.' Their mother threw them a look in the rear-vision mirror but it was wasted because of the angle, which was a shame because it was a goodie.

Their father said 'Don't smoke, girls,' and they tsk-ed and raised their eyes and threw their cigarettes out the window and left the window unwound so as to let the wind blow through their hair, like they were on a cliff, staring out at the nothingness of their lives, like they'd never asked to be born, like no one cared, like they didn't.

'Read the brochure, Mary, whet our appetites,' their father said.

Their mother got the laminated brochure out of the glove-box. 'At Dairyland you can see what goes on at the world's biggest single site dairy factory. The visitor centre features audio-visual and interactive displays, a fascinating glimpse into the way things used to be done and a chance to sample the produce.'

'Crikey, girls, doesn't that sound choice?'

The girls said, 'Yeah Dad, choice,' and wished they'd burnt down the whole fucking school.

No one understood them. They stood two on one side of their mother, one on the other, in front of the black and white dairy cow statue. Their father said 'Move in a bit, Iris,' and the girls said 'I'm Iris!' and 'She's Iris!' and 'Fuck!' and looked at the sky and tsk-ed and said 'Fuck this.' Their father took the photo quickly as they walked away. 
'That's a keeper, Mary,' he said, and, 'We can put it with the others and see how much they've grown. You girls have grown. By Crikey, Mary, haven't the girls grown up? It seems like only yesterday you were strapped down and they were being dragged from your stomach one by one by one. By Crikey, doesn't time fly? Doesn't time fly, girls? Wonder what we'll all look like the next time we come to Dairyland. Good old Dairyland.'

The girls tried to dig their own eyes out but their mother noticed and threw them a look.

'What shall we do first girls?' their father said.

The girls threw him a look.

'It says here the visitor centre features audio visual and interactive displays.' Their mother read from a brochure she'd picked up off the counter.

'Crikey, that sounds like a good place to start, eh girls?'

'Oh - Dad - yeah,' the girls said, 'could we? Could we? Wow, how fucking choice! Awesome because the interactive displays offer a fascinating glimpse into the way things used to be done.' And the girls said, 'If there's one thing we want it's a fucking glimpse into how the fuck things used to be fucking done.' And the girls asked, 'Could we sample the produce?' And the girls answered, 'I do believe we can, Daphne. I believe we can can't we, Dad.' And finally the girls said, 'Oh yes, the fabulous produce. You couldn't go past a good glass of milk, eh Dad? Crikey. How choice.'

Their father smiled, 'That's the spirit girls.' He was turning this around.

For fuck's sake, mother-fucking Dairyland, they would rather cut their ears off with a plastic picnic-set butter-knife that had snapped off at the handle.

The girls smiled and no one said a word until Eltham and then their father said 'Crikey,' and then nothing until Opunake when he said 'I swear, you girls just don't seem happy any more unless you're setting fire to something.' Maybe he should have drowned at least one of them when he had the chance, when they 
were small and separate. The girls smiled and said, 'Did you see those audio-visual displays? By Crikey. Did they go up or what?' and smiled some more. And their mother threw them a look like, how's this going to look on your probation report? Eh? Eh? And the girls smiled. 'I don't know if we'll ever be able to go back to Dairyland, girls. I think that might have been the last time we go to Dairyland,' their father said and the girls said 'That's a shame. I kind of enjoyed this trip to Dairyland,' and laughed and laughed. They were going to say 'The real shame is you can only burn the fucking place down once,' but their mother threw them a look, so they just smiled and looked out at the coast with the wind blowing in their hair, thinking maybe this was turning round, looking up, and they laughed again, thinking anything was possible. 


\section{EVERYTHING}

'HOW'S ALEX?' Hope said. She and Molly were sitting in a café by the river in early spring drinking tea from the same pot. Molly sighed, looked out the window and said nothing.

'What?' Hope said.

Hope was Molly's friend and Alex was Molly's brother.

"“How's Alex",' Molly said shaking her head and smiling.

'What?' Hope said, looking as surprised as she could.

Hope was married the first time she met Alex. He and Molly had been on the street tired from trying to buy a present for a family friend. 'There's Hope,' Molly said, waving, 'Let's have a coffee with Hope.' They were like a house on fire, Molly didn't miss it, couldn't miss it. Alex and Hope laughed, they smiled, they said, 'Oh, yeah, remember that,' like old friends. Three months after Hope's husband left, Molly suggested afternoon tea at a café in the gardens. It was a warm day. Hope arrived first. Molly and Alex arrived together. That was a year ago. 
'What?' Hope asked again.

'I did everything I could,' Molly said. 'This close,' she pinched her fingers together for effect.

'He liked the artist,' said Hope.

'“He liked the artist",' Molly mocked. 'He liked you.'

Hope felt surprised for real. She looked at Molly and didn't say anything.

'Don't blame me - or the artist. You two did it,' Molly pointed from Hope to an imaginary Alex then back again a couple of times. 'We sat in that café and you said, "I'm happy," and he said, "I'm happy alone, too," and then you said, just to make sure it was good and dead, "I'm just not ready for a relationship at the moment."'

Hope tried to remember. That wasn't the last thing they'd said. They'd talk for another hour after that and gone for a walk and talked some more. She'd thought it went well. Then two weeks later he'd started going out with a woman who was an artist.

'I just thought he didn't like me,' said Hope, only meaning to think it, but saying it out loud.

'And that,' said Molly, 'is what chokes it before it starts. You think he doesn't like you, then he thinks you don't like him and neither of you want to look like you like someone who doesn't like you, then before you know it he's going out with the artist, who's as dull as ditchwater, and you're alone and asking me, "How's Alex?", hoping beyond hope he's single again but - know what, Hope? If he was it wouldn't make a blind bit of difference because you and Alex would be so wary that eventually one of you would say something and it would all be off again.'

'He doesn't like the artist?' Hope said.

'He loves the artist,' Molly said. 'He's happy. That's not my point.'

'It all worked out fine then,' Hope offered playing with a teaspoon that was lying on the table. 
'It looks that way,' said Molly and then she said nothing for a moment, hoping it would sink in - how no one should settle for fine, how they'd both be much happier if they hadn't said what they'd said; if they'd just said what they felt and not been so worried about things working out fine. Then she asked how work was.

'Work's work - you know,' said Hope. Molly knew.

'It's busy,' Hope added, 'What about you - have you and Ned set a date yet?'

Molly said the wedding would be in January. She would be baptised in December and the wedding would be in January.

'I'll grow my hair,' said Molly.

'Summer wedding,' said Hope.

The wedding invitation - Hope's invitation - she returned with 'and partner' struck out. Molly counselled bringing someone.

Hope said, 'Anyone?'

Molly saw her dilemma.

They met for an early dinner and ate hot soup with noodles. As Molly put on her jacket she said she had to meet her fiancé. Hope laughed and said, 'That sounds flash,' and Molly laughed too.

Hope walked home along the river, like an actor in an eighties music video for a new wave song about leaving. The sun had no heat in it and the ducks made her cold.

Molly lived by the beach and swam most days. She said dinner would be around seven but Hope could come any time after work. Alex and his artist were coming too - was that all right?

'Of course,' Hope said, like Molly couldn't imagine how all right it was. Like nothing had ever been so all right before. 
'I'll see you after work,' Hope said.

At work things went badly. The salon was busy. The manager said, 'Stop running,' to anyone who was. She asked if Hope could keep an eye on the running while she went to lunch.

'It's supposed to be a relaxing place,' the manager said.

A woman handed Hope a page ripped from Hustler magazine. Hope folded it so only the head of the woman was showing not the motorcycles or the men or her breasts. The woman wanted to be blonde - Hustler magazine blonde. Hope had three clients waiting all with wet hair. An hour later the person doing the Hustler women's colour asked Hope to check it and as they walked over whispered something about 'very hot' and 'metallic dye.' They rinsed her hair and it came out in Hustler-blonde jelly clumps. The manager came over to ask if anyone had been running and looked in the basin and looked at Hope and Hope looked at the jelly blocking the plug hole in the basin. She asked someone to put a conditioning treatment on the woman's hair for fifteen minutes.

Hope walked through the mall to the staff toilet and threw up and prayed, 'God, if you get me out of this one I'll do anything - anything.' When she got back to the salon the woman's boyfriend was there. He was huge and wearing a gang patch.

'For some reason,' Hope said, 'it hasn't taken. We'll need to do the colour again. We won't charge you for it.' She would do anything to get out of this one.

By six o'clock everyone had left the salon except the woman, her boyfriend and Hope. He swung oversized in a chair reading Women's Day to them both. By seven o'clock Hope had put what was left of the women's hair up like a southern belle and she and her boyfriend left smiling.

Hope saw every side of herself in mirror after mirror after mirror as she cleaned up. She washed her hair leaning over a basin and dried it with the music turned off. 
That's why it was late and dark when Hope got to Molly's house. She walked up the path, over-grown with sea grass and flax. She walked across the lawn in the noise of the coast under a full moon in a clear sky and knocked on the glass of the French doors. Molly shouted, 'Come in,' and opened the door.

Alex's girlfriend was at a yoga retreat and Molly's fiancé had been called in to work.

'That sounds flash,' Hope said.

'Make yourself at home,' Molly said.

As Hope entered the lounge, walled with books and art, Alex stood up. She took a seat as far away from him as possible in the small dull-lit room.

'I'm just finishing dinner,' Molly said as she walked back to the kitchen.

'We waited for you,' Alex said, not in a cruel way, 'Shall I take your coat?'

'Oh yes,' Molly shouted from the kitchen, 'For God's sake Sasha, take her coat.'

They stood as in a queue and Alex's hand touched Hope's arm as he took her coat.

'She'll wear it all night otherwise,' Molly said passing Alex in the doorway, 'so she can make a quick get-away.' She carried fresh bread and shouted for Alex to bring the pasta on his way back.

Molly said grace.

'Isn't this dreadful?' Alex asked Hope, throwing a thumb at Molly to indicate he meant the praying.

Molly hit him playfully, still praying with her eyes closed and head down.

'Honestly,' Alex said, 'don't you think this is dreadful?'

'You're the one breaking bread,' Hope said.

'Converted for a man,' Alex said.

'Jesus,' Hope said. Alex didn't mean Jesus.

'She won't watch Almodovar any more,' he said.

'Probably for the best,' Hope said and they all laughed. 
'Dig in,' Molly said.

Hope told them about the jelly clumps and the gang patch and the pornographic picture and said, 'I prayed.'

'No atheists in the trenches,' Alex said and they all laughed. They laughed like they used to laugh together before the engagement and the afternoon tea. Like the teacher was out of the classroom or the cat was away.

When the meal was finished they drank, still sitting at the dining table, and shouted about politics like someone, other than them, was listening.

'God will look after it,' Molly said.

'You don't really believe that do you?' Alex said.

'God will look after it one way or the other,' Molly said, 'and for now I'm acting as if I believe that.'

'You realise how stupid that sounds?' Alex said, 'Hope, tell her how stupid it sounds?'

Hope agreed, perhaps because of the wine, that it did, indeed, sound stupid.

'No stupider than sitting here shouting about it,' Molly said and laughed and it was made light of again.

They tip-toed at it all night: the wedding, the conversion for the wedding, what she was wearing to the wedding. Like it was just for the sport of it - an exercise in wit-sharpening, like some contest of the privileged classes. No one was trying to change anyone else's mind - not really.

The seats at the table got uncomfortable and Alex looked at his watch and something broke a bit in the spirit of it all.

'When does she get back?' said Hope as if to make sure it was good and broken. So no one thought she was trying to fix it.

'Tomorrow,' said Alex, 'later in the afternoon.'

'Mmm,' said Molly and began to clear the table.

'What's that supposed to mean?' Alex said. 
'What?' said Molly.

Hope stood up, took Alex's plate and said, 'How close is the retreat?'

'About an hour's drive,' Alex said. 'She caught a bus. I'll pick her up, later in the afternoon - tomorrow.'

Hope nodded and looked at her watch so it looked like it didn't matter to her and she was just making conversation.

Molly came back into the room with a new bottle of wine and said, 'Wine?'

Hope looked at Alex and Alex looked at Hope like actors in a Mexican stand-off.

Molly said, 'For fuck's sake, come and have some more wine. Everything's not everything - it's just a glass of wine.'

Alex and Hope laughed.

'Well, Jesus,' Molly said walking unsteadily into the lounge, 'you never do anything - either of you. You always think everything's everything,' she struggled with the wine bottle and the cork screw then handed them to Alex, 'you're always like "Oh. Oh. What if this is everything? I better sit here in complete stasis until I find out if it's everything. Oh, there it goes. It wasn't."

Alex poured the wine. 'I'll tell you one thing,' he said, 'I'm glad this religion kick is giving you such clarity and articulation.'

'Smart arse,' Molly said throwing a cushion at him and they both laughed.

Hope leaned in the doorway and watched them.

'Stop looking poignant and come and have a drink,' Molly said to her and she joined them in the lounge.

They drank and talked. Molly said she believed she was doing the right thing. Alex and Hope said they supported her fully. Molly cried a little and Hope hugged her. Alex said he was only joking before. Hope said, slurring a little, 'If you do this, you can be sure of your afterlife.' Alex wasn't sure how saying that helped. Hope said, 'On the up side.' Molly nodded and drank more wine. Alex put on 
some music and they talked some more and laughed some more and forgot about everything.

The wine ran out and the music stopped and they sat in silence for a while. Molly made a snuffling noise curled up beside Alex on the couch.

Hope said 'Is she faking?'

Alex poked Molly. She repositioned herself and stayed asleep.

'She's faking,' Hope said, 'Molly. Molly.'

Molly stayed asleep.

'Don't wake her,' Alex said.

'She's not asleep,' Hope said. 'She's faking.' Hope stood up to shake Molly. Alex caught Hope's arm and said, 'Don't wake her up.'

The house was quiet.

‘We could go somewhere,' Alex said.

A key turned in the lock and the door opened. Alex let Hope's arm go. Molly stirred and woke. Ned came into the lounge and said, 'Hi Alex - Hope.' He kissed Molly on the head, she stretched.

'I'm going to get a coffee,' Ned took off his coat, 'Does anyone want a coffee?'

'I'll help,' Hope said and followed him into the kitchen where he sat on a stool and she made coffee. She asked how his night had been and he sighed by way of a reply.

'How about yours?' he said.

Hope shrugged then nodded and said, 'Yeah. Good.'

'Where's Alba?' Ned asked.

'Yoga retreat,' Hope said. 'She gets back tomorrow. Alex is picking her up later in the afternoon.' She straightened the tea towel that was hanging on the oven handle. 
When she came back into the lounge Alex was gone. She tried to hide the fourth mug; ashamed of it - of herself. Like she and the mug were the only things in the world. Hope drank her coffee fast and it burned everything in her mouth tongue, cheek, gums. She looked at her watch. It was the tilt forward that did it. Hope said, 'I better go,' looking up to hold the large tears where they were, to stop them from tipping.

Molly said, 'Oh Hopie - stay.'

'No,' Hope said.

Molly saw Hope to the door and they hugged. Hope stood back and wiped her eyes like she was tired and looked at the wall behind Molly.

'You two,' Molly said - or 'You too,' Hope wasn't sure.

'Your coat!' Molly went to get it.

Hope walked across the lawn in the sound of the night and the moon. As she drove home she thought maybe Molly had said 'You to...' like she was telling Hope where to go - to make everything all right - but it was too late to ask and it made no sense - none of it. 


\section{JESUS ALREADY HAS}

IT ENDS UP, inevitably perhaps, like the chicken-fox-grain puzzle. You set it in Iraq and what are you going to do with the ukulele orchestra. There's something ... is it the word - you koo laylee? Is it my dad singing Ukulele Lady? Waving his arms around? It's tonal. It's connotational. It's a small guitar with four strings used for ironic effect too many times. I have two friends who are Lutheran. I'd never met Lutherans before I met these two people. They're from Minnesota. They live in Minnesota; their parents are from North Dakota and South Dakota, respectively. They're married, the two friends - and their parents. He came to implement a content management system at an insurance company. When it became apparent he would he here for a while she came, with their son, who turned two in December - well before Christmas, so don't feel sorry for him because his Grandparents were here from South Dakota and everything. It was the first time they'd been to New Zealand and they liked it - I saw the photos. 
They're Lutheran and he went to university just out of Fargo. They do the accent and we laugh. They know about Gore and I know about Fargo, it's a cultural exchange. Her brother - let's call her Ingrid, because that's what I always call her by mistake and let's call him something like Dwayne - no that's too close let's call him Dwight. That's my father's middle name. Ingrid's brother went to Iraq. The last time Dwight was here I almost ruined our friendship by saying I didn't think America had any business being in Iraq. A third person, who was there, made those shut-the-fuck-up eyes at me and I got mad and talked more and ended up saying the soldiers were complicit in the war by being there. I thought I had every right to say that. I was engaged to a soldier once who went to East Timor and got to put the decapitated head and mutilated body of his co-worker in two black body bags and carry them through the jungle. It was bandits. Not Lone Ranger bandits. He was polite. Dwight is always polite. I think that's one of the things with Lutherans. They're polite.

I used to call him my Republican friend - Dwight - to my hip friends. I disagreed with most of everything he said, my Republican friend, but I enjoyed his company and his wife was nice too. Before she moved to New Zealand for good she visited Dwight about seven months before their son was born. On the way to picking them up for dinner I told myself I needed to watch my language and manners to make a good impression. The first thing she said was 'Our room smells like arse!' We didn't talk about politics but I wanted to. I wanted to know how her brother was. It felt like he'd been in Iraq forever and I needed to make up for the complicit soldier thing because I felt like I'd acted like an arse.

I liked to read their blog, the Lutherans, and every now and then on their blog there was a message from Ingrid's brother. He was giving clothes and food to a family in Fallujah who had not much after the Americans. What they did have was full of holes and blood and fear - that's what the TV said. Dwight said the media didn't show the good-news stories. He did. On his blog there were often photos of two small girls wearing clothes that Ingrid had sent. I was mean about 
the clothes, sometimes. I was mean about the fact he was preaching Luther Jesus to them, and capitalism. He thought he was doing the right thing. Actually - no - his sister and brother-in-law, my friends, Ingrid and Dwight, the Republicans, said they thought he was doing the right thing. The impression I got was he wanted the fuck out of there and felt intense guilt for what his country was doing and was trying to make up for it by bringing Jesus and capitalism to the two small girls. I got mean about how the government probably made him send photos of the clothes and the children. Our friends were kind and patient.

Ingrid cooked a Thai curry. She couldn't buy snow peas so she bought mixed, frozen vegetables and picked out all the snow peas. Sometimes I said she made so much effort because she wanted to convert people to Lutherism. Her parents were beef farmers. There must have been a time, at some point, in all the times we hung out - Ingrid, Dwight, their son and I must have walked past the bucket fountain in Cuba Street. I just can't think of any time that warrants being in this story, which I think is quite heart-rending and not too preachy. I'm not trying to say the soldiers aren't complicit in the war in Iraq, or that they're victims too.

It was time for Ingrid's brother to come home when she and her son came to live in Wellington and I spent more time with her than her husband. Dwight and I weren't working together any more. Ingrid and I had lots of fun days and lots of interesting talks. I would always say what I thought she wanted me to say. I wanted her to like me. I wanted her to think I was on good terms with God because I liked her company. I was a little anxious that I wasn't on good terms with God, knowing at any time God might tell her that she couldn't hang out with me any more. Her son was fun too and tongue-tied. She really liked American Idol. The first time she saw Dwight he was singing in a choir. Ingrid said she thought he was hot and God must have thought so too because he was Lutheran. Don't think it's some kind of light-striking miracle coincidence, him being Lutheran too - she saw him performing in a Lutheran choir at a Lutheran college she was visiting. I feel great affection for these people - I hope I'm getting that across. They took me 
to see Constable. Did you notice how everyone called it Cuntstable? I spent a lot of time practicing saying Contstable so I could talk to them about it. That's an exaggeration for the sake of a one-liner. It's a good one though - the one-liner: I didn't want to say Cuntstable to my Lutheran friends. Another good one-liner is that we were walking round the Constable exhibition going 'Hey Wayne! There's Wayne. Hey Wayne!' Dwight's name is Wayne and The Haywain wasn't there.

I was at her house about a week before her brother came home. She was excited - on fire with the Lord. She told me everyone was praying for her brother because he had to do one more thing before he could come home and it was a dangerous thing and everyone was praying and she was praying. I wasn't praying. I didn't know about any of this until I got to her house. He was travelling, she knew that, and she prayed, 'Jesus, please put a protective bubble around him and the vehicle he's travelling in.' When I got there she'd just heard from him and, this is the exciting part, he said there had been a bomb and it had hit the vehicle he was travelling in and he said, 'It was as if we were in a protective bubble and it lifted us up and we are all safe,' and it happened, allowing for time differences, right when she'd been praying and my stomach did that roller coaster thing and I thought 'Jesus is good,' and immediately, 'What is Jesus doing for the armless mutant babies being born to the Iraqi people because of the depleted uranium munitions the Americans are using?' But mainly I thought 'Jesus' in that 'far out' way that's probably blasphemous and I was happy for her that her brother was coming home and getting married and I thought a bit about my ex-fiancé. I didn't think about how he killed himself. How he tried to hang himself in the garage but the wooden beam broke and he ended up gassing himself in his car (which shows the sort of commitment to task a soldier needs). I didn't think about the view he had down the drive-way of the street as he suffocated himself or how all he had to do was open the door - which was what I usually thought about. I thought about how he came home from East Timor, after carrying the head of his co-worker in a bag, and how anything that was happening after that didn't pretty much matter. How he 
started to live above everything. Like a superman. How he said 'Please believe me! I was complicit,' and how I said 'Forgive yourself - Jesus already has.' And we held each other next to the fountain in the Christchurch Botanic gardens - the one with the animals and birds, at night, listening to a ukulele orchestra which included a pregnant woman from Iraq and nothing fitted together well with anything else. Soon after he left, saying most of the hurtful things people say when they leave and that all our friends could tell I was deluded and so could probably everyone else.

There was a lot of hugging and kissing and singing at the airport when her brother got home and at his wedding. He was going to be a preacher or whatever they call it in Lutheranian. He lost his faith. I think that's how Ingrid put it, that day in Wellington, the day of the bomb and him safely emailing from the barracks. They test your faith at Luther preacher training. They test your blood pressure at military training. She said she thought God had wanted him to go to Iraq to find his faith, she said the bubble episode would have restored his faith. How could it not? My mother took me out of religious education. The teacher told me I was going to go to heaven because I believed in Christ but my parents were going to hell because they were dirty atheists. Eternity without my parents didn't seem too heavenly. I didn't sleep for days, praying. I told my mother she needed to accept Jesus into her heart for my sake. She said she wouldn't and took me out of religious education. I stopped believing in the hope I would go to hell with my mother and father and spent Wednesday mornings with the Jewish kids in the library. People traveled from all over America for her brother's wedding. Her father did some weird barbeque thing with lots of cows off his farm and some sort of forty gallon drum arrangement or other. The way she told it, it sounded lovely.

There was a tree trunk on her father's farm where her brother used to go a lot to think and look at the sky, empty of God after preacher school. Her father crafted something out of a small piece of wood from this trunk. It might have been something to wear around your neck or something to hang. I could check it out but 
for now just know it was something beautifully crafted and incredibly significant. Her husband, Dwight, had to present the wooden thing at the wedding because Ingrid's father thought he would cry, which you would. If your son had been grabbed from the jaws of death by a loving Christ and laid gently in a church, his faith restored, standing next to the woman he loved in the presence of a large group of people who loved both of them. 


\section{HAYDON'S PICTURE}

MARCH 25, 1820

Benjamin Robert Haydon sat in the coffee-room watching the clock inside the bar. Perhaps no one would come. Everything was in place; servants at their posts, chairs all in a row. It was odd that no one had come before twelve. Surely someone ought to have been over-anxious. He looked at the clock, twelve-thirty. Yes, nobody would come, it was clear. He stole back to the hall.

'Anybody come?' Haydon said.

'Yes, sir,' said Sammons looking knowing, 'Sir William Scott is just gone.'

Haydon smiled, 'That will do; he always goes to every exhibition on earth, and brings everybody.'

Away Haydon went and had a good lunch, drank a couple of glasses of sherry, and went out about half past three, ready for anything. As he turned an anxious eye toward the Hall he saw a crowd of carriages was blocking Piccadilly. 
'Ha, ha, that will do,' Haydon said, and bounding over, found the whole passage full of servants, and all the bustle and chat and noise and hallooing of coachmen, of a regular rout at noon-day. Up he went, proudly. Sammons was seven feet high; there was no speaking to him. The room was full. The Persian ambassador and his suite arrived. His fine manly person and black beard, with his splendid dress, made a prodigious show, and he said, 'I like the elbow of soldier.'

The room was full and in the east side, hung four feet off the ground and tipped forward at the top about six from the wall was Haydon's Christ's Triumphant Entry Into Jerusalem. After six years of struggle, ill-health and financial distress, by the help of Jeremiah Harman, Mr Coutts, Watson Taylor and Thomas Hope, Haydon's Jerusalem hung in successful conclusion. It seemed doomed, even to the end. The first attempt to hang it had snapped an iron ring strong enough to carry anything.

Dogged with difficulty, the painting was pitched into its place. Haydon walked back forty feet, turned around and at that moment the head of Christ struck him as a failure. He had endeavoured to combine in it power and humbleness, but power took the lead, and by overdoing the intellectual a little he had injured, he feared, the simplicity of that divine mildness which should always be the ruling expression in the Saviour's face. He had painted it seven times, had overwrought his imagination and feelings. He had overdone it and, like all overdoings, it was weak. The defect was not in character but in execution; when it ought to have looked best, it looked worst, and looked well only when the whole picture could not be seen.

Yet the room was full. Haydon looked around. Keats and Hazlitt were up in a corner, really rejoicing. Haydon thought, 'Poor Keats has never looked more alive, this is the power of my Jerusalem. He is as if, at once, raised from the dead like Lazarus and returning triumphant like Jesus.' Haydon looked from Keats to the painting, how could his Christ head compete with poor Keats? It was as if he had come from his sick-bed just to spite Haydon, but it was probably Hazlitt. 
Hazlitt was the bawler, and the brawler and the whorer. Haydon looked at Keats and Hazlitt across the room, bitter at himself and at Hazlitt and at poor Keats for being so poor.

John Keats couldn't bear the city but he would venture to the West End to see Mr Haydon's picture, which was just finished and about to make its appearance. The doctor had recommended he make not the slightest exertion but Keats said he was feeling better every day and would think himself quite well was he not reminded now and then by faintness and a tightness in the chest. He stepped outside for the first time in what felt like months and began at a measured pace towards London.

The spaniel should come to Hampstead. He would write his sister as soon as he had strength and wit. He was sure he could find a mistress or a master for it. Truth be told, he could probably turn it loose in the common road and it would find an owner. It would be attended to like a prince. His mind was made up; Fanny should send the dog over to Hampstead.

Keats looked at the sky. It could rain. The air smelled of spring but it could rain and he could be caught in it. A gentle spring shower should do me in, he thought with a smile. The pleasure they would take in that; the boy Keats done in by a spring shower on a slow walk to London. From the first sign he was ill, he imagined something would remain undone, half-finished, and every time he started something he wondered, will it be this? No one wanted to live forever. He would never finish Hyperion. He exhaled quickly by way of a cynical laugh. Maybe this is how I shall impress Mr Hazlitt, he thought, with something unfinished and lousy with promise. Maybe this is how I am to live to him.

Keats stopped to rest against a low stone fence. Out of all of them, today, he could bear only Hazlitt. He felt the tightness of his chest and his heart beat as if it were shouting to be heard three miles away. Let him be there and let everyone leave us to ourselves, he thought and began again on his way to Haydon's picture. 
'It's a good likeness.' It was Sir George Beaumont and he gestured over the crowded room at Haydon's picture.

‘Of whom?' William Hazlitt said.

'Of you,' Beaumont offered, 'and Wordsworth. Of Keats.'

'And Jesus?' Hazlitt asked. 'Is it a good likeness of Him, Sir Beaumont?' Although he looked at his feet, Hazlitt was watching Keats. He'd arrived and immediately been captured by Haydon, then David Wilkie and now seemed in conversation with an educated country woman who was putting him right over some thing or other.

'It is a good likeness,' said Beaumont. Hazlitt didn't look up and Beaumont was dismissed.

He can smell it, Hazlitt thought. That morning, Hazlitt picked his jacket up from a floor and walked to the boarding house where he lived. He found one clean shirt, pressed and white and hanging in the wardrobe in the corner of his room. He wore it now, over the filth. They could all go to Hell. His stomach ached like it was rotting. Keats was attentive to the woman but Hazlitt knew he'd seen him; he was in the process of changing his course toward Hazlitt when he was captured by the bitch, she was talking on and on and Keats was attentive, like he had all the time in the world. He would get to Hazlitt eventually. Hazlitt would look at his feet until he did, because no one but Keats would bear him today.

'I was unsure she would ever release you,' Hazlitt said.

'The risk is higher when I have further to come,' Keats said. 'Why are you in a corner, Mr Hazlitt?'

'It is a good vantage,' said Hazlitt. 'There is Beaumont soliciting favour,' he pointed, 'and Haydon wiping his brow.'

'I see,' said Keats surveying the room, 'and look, Mr Hazlitt, Mr Wordsworth has just arrived.' 
'Oh, why yes, Mr Keats. Well, then we shall have some sport. I should think he will want his likeness to be Jesus before the afternoon is out.'

'I believe he is questioning Haydon about it now.'

Keats and Hazlitt both looked away from each other, over the crowded room.

'I have never seen death but once,' said Hazlitt, 'and that was in an infant. The look was calm and placid, and the face was fair and firm. It was as if a waxen image had been laid out in the coffin, and strewed with innocent flowers. It was not like death, but more like an image of life. No breath moved the lips, no pulse stirred; no sight or sound would enter those eyes or ears more. While I looked, I saw no pain was there; it seemed to smile at the short pang of life which was over.'

'No one wants to live forever,' said Keats.

'I could not bear the coffin-lid to be closed - it seemed to stifle me; and still, as the nettles waved in a corner of the churchyard over his little grave, the welcome breeze helped to refresh me.'

Hazlitt has been whoring, thought Keats.

'I suppose the painting will be a success,' said Hazlitt.

'I suspect so,' said Keats. 'I was thinking on the way over that I shall write Fanny and tell her to send the spaniel.'

'That is a fine idea. Good God,' Hazlitt said, 'you could let it loose on the common road and it would find an owner in Hampstead.'

'My thought exactly,' said Keats, smiling.

He shall never finish Hyperion, thought Hazlitt. He may find a home for the dog but he will never finish Hyperion. Without it we shall all go to Hell.

The penitent girl, blushing and hiding her face, brought to Christ by her anxious mother, was a hit. The Samaritan woman and centurion spreading their garments in the road, Wordsworth's bowing head, Newton's face of belief, Voltaire's sneer, the enormous shouting crowd, and the action and position of the Saviour, with 
Peter and John, were all decided favourites. But Haydon suspected the Christ's head was not. It startled people. It was not the traditional head; not the type; not orthodox. It was on the verge of blasphemy.

Everybody seemed afraid, when, with all the dignity of her majestic presence, Mrs Siddons walked in, like a Ceres, or a Juno. The whole room went dead silent, and allowed her to think. After a few minutes Sir George Beaumont, who was extremely anxious said in a very delicate manner, 'How do you like the Christ?' Everybody listened for her reply. After a moment, in a deep, loud, tragic tone she said, 'It is completely successful.' So Beaumont and all Haydon's friends were up in the clouds, but Haydon knew it had failed and so did Hazlitt and soon Keats would be dead. 


\section{YOU MIGHT BE RIGHT}

'WE'RE VEGAN.' He says it, kind of waving his hand to indicate he means all of us: me, him and the baby. 'We don't have any animal products.' They smile. We sent an email earlier. Before we got here - to Samoa - we sent an email to the hotel to check we could eat something. The person we sent it to sent it to the maitre-d', who sent it to the chef, who sent it back to the person we sent it to, who sent it back to us saying, 'This should be fine. Not a problem.' The manager, the person we sent it to originally, forgot to delete the messages underneath his. He had forwarded our email to the maitre-d' with a message saying, 'Get a load of this *grin*.' The maitre-d' forwarded our email and the manager's message to the chef saying, 'Sorry - this is bound to be a pain in the arse.'

We feel bad before we get there. We take silver packs of soy protein and vegetarian luncheon sausage. I feel like a spaceman. Everyone we know who was vegan is freegan now. People say we care more about animals than people. I watch a documentary showing someone killing baby cats - kittens. One of the last vegans 
I know says she can't watch it. Someone says vegans should be exempt from watching it. Someone else says that's shit, if she expects other people to watch it she should watch it herself. I hate cats. I watch about ten seconds more of the documentary and I can't watch it. They poison some dogs with cyanide. The dogs look like frightened children. I don't particularly like children either. When I meet people I try to wait as long as possible before I tell them - about the vegan thing. Most people don't like children particularly - or cats.

We go for a drive. We rent a car, we pack up our vegetarian luncheon sausage and some white, bouncy bread and go for a drive. There are dogs everywhere. I send an email back home saying, 'We're having a great time, there are dogs everywhere in Samoa.' A lot of the dogs have bits missing: ears, eyes, legs. On Savai'i, while we're waiting for the ferry, a group of them surround us like a 1980 's horror movie. The baby teases them from her car seat. She shows them her vegetarian luncheon sausage and they growl. We say, 'Don't worry the dogs.' They look like they have rabies. Neither of us have seen a dog with rabies, but we agree these dogs look like they have rabies. We wind up the windows and drive somewhere else to wait for the ferry.

For dinner we eat palusami and taro chips. We stay in a fale on Savai'i and we eat curry and rice. We eat more palusami. Palusami quickly becomes our favourite food. I have my photo taken outside the Marlon Brando fale. We meet Aggie Grey's grand-daughter - she dances for us. There is fire every night: firedancing, fire-twirling, and jumping from the top of a palm tree into the swimming pool holding fire. We eat more palusami and lots of star fruit. We see pawpaw growing on trees. Anywhere else I've been I hate pawpaw, but I can eat it in Samoa with pleasure. Everywhere we go, it rains - big, fat, warm rain. I had a different holiday in mind. I thought it would be sunny all the time and I would be lounging by the pool, getting brown, but it rains and often isn't swimming weather. We try to go snorkelling. We take the baby out a wee way, and I see a fish and panic and don't go snorkelling any more. I think of Jaws and Piranha and Piranha 2, where 
they could fly. I don't like fish. I don't like animals where I can't see them - where they can creep up on me. On the way to the snorkelling beach we see a dead dog stiff, with its legs up. We agree someone will come for it. On the way home it's still there, only fatter. It'll burst if the sun stays out. It's in a ditch.

They have a huge banquet that night, Aggie Grey's grand-daughter dances. There's fish everywhere, raw fish marinated in coconut milk, and fresh limes. I think about the fish that were there while we were snorkelling - how sneaking up on someone isn't a nice thing to do. There are shellfish. Shellfish are like vegetables to me. 'No central nervous system,' I say to the baby. I order palusami and a vegetarian pizza with no cheese and can they check there is no butter or milk in the pizza base. The waiter smiles. I feel elite in the worst way. We all eat palusami and taro chips, the baby gets some of it in her hair and tries to feed the rest of it to a cat that lives in the hotel. The pizza has parmesan on it, so I order some more palusami. The parmesan is a test, an accident or a misunderstanding. I leave the pizza untouched hoping that someone will eat it in the kitchen. Waste, food miles, hypocrisy, reliance on capitalism, elitism - someone mentions one of these things to me most days. In New Zealand the doctor says, 'restricted diet,' a couple of times and I figure sooner or later someone is going to take the baby off us. The Plunket Nurse says, 'Just a glass of milk a day would do it.' I think about a million cows in pain and all the rivers drowned in shit and say, 'Yeah, that would do it.' I start lying to the Plunket Nurse. I say, 'Yeah,' when she says, 'Is she having any meat?' The baby has never seen meat. I stop going to see the Plunket Nurse. Someone asks me if I've ever given the baby a choice to eat meat. While we're in Samoa the baby eats pigeon shit and some weird fluffy plant. I say, 'Yeah, nah, I haven't done that.' I say I see their point, but I don't, not really. I pretend to cooperate. I say, 'You might be right.' It's my secret way of not getting into a fight when I don't agree with someone. The nutritionist at the hospital tells me I have to go back to Plunket. I say, 'Okay,' but I might as well have said, 'You might be right.' The baby and I walk back through the hospital car-park, there's a cold and 
dry wind. 'It's warm enough in Samoa to grow beans and wet enough to grow rice,' I tell her. 'That's a perfect protein - pulses and grain.' If I could catch a wild pig with my bare hands and kill it with my bare hands and eat it raw I probably would.

One overcast day in Samoa we go to Robert Louis Stevenson's estate. There are fire places in most of the rooms. We walk up the hill to the memorial in roman sandals. Black lizards move as we walk close to them. At first I think I'm seeing things, from the lack of protein and iron and the humidity and the long walk up hill, but then we see them and they join us and the baby laughs and tries to catch them with her bare hands. 


\section{EXIT WOUND}

WHEN SHE SAID she'd never really liked Steven Segal, Lance was confused. Why would she lie about that? Why would she choose now to be honest about that? Were they still going to see Exit Wound? Standing, as he did now, with an ice cream chocolate-dipped and nutted, looking at the woman he loved, Lance began to suspect he was out of his depth. He would say something, of course he would, he couldn't just stand there looking at her - but what was to be said?

She was still talking. He could see her - talking. So maybe he could nod. Was nodding good? Was she nodding? He began to nod and her face changed in that split second and he realised nodding was not good, so he made a neckstretching gesture which, as her eyes rolled and she turned away, he realised could be construed as frustration, aggression, raw wife-beating, child-raping male rage, repressed to a manageable level but always at risk of exploding and taking over the world.

He reassessed the situation. 
He was still in the queue to see Exit Wound. She was still in the queue to see Exit Wound. He was pretty sure they were still going to see Exit Wound. 


\section{UNTIL FRIDAY}

I WAS WONDERING, as I mooched around the house this morning, if you knew that C. K. Stead - your swimmer - wrote Smith's Dream, the book Sleeping Dogs is based on?

Thank you for that info. I just find it interesting to see someone who is famous hanging out with all the swimmers at Kohi Beach. Spoke to Brent this morning but didn't use the camera as I was a bit tied up with Paul and Shona. They've left now for Mangaweka. Christine and Sam's little girl is lovely. Looks like she had a pretty gentle arrival. Looking forward soooo much to seeing you all. It has been quite hot here but soon to have rain I think. Don't know how much though. Anyway until Friday. See you. 
Christine and Sam's little girl is truly lovely, isn't she? I'm sorry we didn't deliver your grand-daughter to you in such gentle condition. Isn't she a good swimmer though?

What's the name of that little bay where we went swimming that night? It begins with $B$ I think. Ta.

Balena Bay, I think.

Only this morning she was down at Balena Bay; goggles in hand, eating sand and waiting to dive in. You would have got a kick out of it - there were heaps of famous people there: Katherine Mansfield, Alexander Turnbull, Arthur Wellesley. You could hardly move for all the famous people on the pebbly beach. We weren't quite as impressed, as you can imagine, all the people left little room for swimming and you know how Tallulah likes her space. She's a fighter though. On the way out of the rough water she dunked Douglas Lilburn, who came up spluttering and spitting and crying foul murder. She just kept swimming. We laughed from the shore, sparking a few disgusted glances. I tell you, even now when I think about it I can't stop laughing. It was funny. You should see if Carl would be keen to come down one Saturday. The water temperature doesn't change much from season to season down here - it's always bloody freezing *teehee*. We are also looking forward to seeing you; my back is out with anticipation. And then it won't be long before her first birthday. That will be a day won't it? Lots of eating and balloon animals - it's hard to believe it's almost a year since she made her bruised and swollen (was that what you called it?) bashed-about arrival. How will that play out in the smacking debate, eh? Who are Paul and Shona? And why were you tied up with them? Haw-haw! Nudge-nudge, wink, wink, say no more. Oh, but won't we have a laugh? Fighting all the time, not listening to each other. It will be a blast! 
Remember when you slapped me across the face in that supermarket in Emirates? That was exotic, eh? Quite the White Rajahs. It was cool - the supermarket. It is so hot in Emirates. Remember we swam in the China Sea? I really did wind you up, eh? Remember when the Police stopped us? On the way home from that football match and then the Border Guards took our passports in Malaysia? That was a laugh, eh? Especially with those signs up everywhere with nooses and DRUGS in big letters. Ah, drugs. Remember that time you had to bail me out and lift me up and pretty much carry me home. That was the flat with the kitchen in the lounge, the one where I lived for seven days behind the toilet cistern because of those fireworks. Did you know Paul doesn't speak to me any more? He got sick of coming home and finding me hiding behind things. It was awkward if he brought people over. For a while he stopped bringing people over, then one day he left. I cried and hit my head on the steering wheel. He said he had to take his phone off the hook because I kept calling him. I can't remember that. Can you remember that? Sands through the hour glass. Anyway - until Friday. See you. 


\section{YOU'VE COME A LONG WAY, BABY}

\section{MILTON KEYNES IS A NEW TOWN. When I ask what it's}

like to live here everyone I meet says, 'It works.' There's one set of traffic lights and not very good buses. The centre of Milton Keynes is the longest shopping mall in the world. The brochure says it was built around an ancient oak tree that still survives in an open area. There's a market in the car-park every Sunday and an indoor ski field. In Strontlium Dog comics, Milton Keynes has become a mutant ghetto of the future.

It's a crazy situation. A man rings to ask if Bo and I want an all-expenses paid trip to England to go to a convention in Milton Keynes. It's crazy even before that, really. They hold an open call for people over six feet and people under five feet. People come and are cast and Bo is cast as the Witch King because he's one of the tallest. They make three movies at once. Film stars, real film stars, come to Wellington and go to restaurants and bars. Teenagers from local schools out shopping meet film stars out shopping. 
We have a week north of London first - Stevenage - in a huge tenement block. People in Stevenage look like they're taking the piss out of themselves. It's chav heaven. There are whole families in shell suits. We catch the train into London, go to galleries and look through the bars of Buckingham Palace. We see squirrels and marble steps that are worn away by millions of people, over hundreds of years, climbing them. We sleep on the lounge floor and annoy each other - but it's cheap.

On Thursday a black car turns up outside and the driver calls and asks if we can come down because he's a bit worried about leaving the car there. We come down in the piss-smelling lift and he puts our backpacks in the boot of the shiny, black car that local youths are now standing around, and shouting at. We get driven to Milton Keynes in the grey cold.

The hotel we're staying in is like Fawlty Towers. There are ducks and people in sunglasses arrive and hug each other. All the way in the car Bo says, 'Be cool, just be cool.' When the big stars start arriving at the hotel I am very, very uncool. When I say big stars, I mean Giles from Buffy, and all the hobbits and people from Star Trek, Next Generation and Deep Space Nine. One of the hobbits gives Bo a hug, says, 'Boooh,' and pats him as far up his back as he can reach. A taxi arrives, it's the female cyborg from Terminator 3. Someone carries her luggage for her. We go to our room and Bo goes for a walk. He says he saw a fox but I highly doubt it. He's nervous. It's all about him. Tomorrow he has to earn our trip to London. At dinner I look around and think, this is ridiculous. I want to say to him, 'Don't be nervous, this is ridiculous,' but I'm not sure if it would help or hinder.

The next morning a limo picks us up. We travel with a former child star and his wife who looks like a contestant in Miss Universe. A man who was in Goonies with the child star, is reading the paper. He starts ripping out an article and says, 'I gotta save this for Benicio - he wants to play Che.' He seems to be saying it to me, so I sort of smile and nod. Nothing has really prepared me for a conversation of this nature. 
There are hundreds of people at the mall when we get there. It's a bit of a mutant ghetto welcome. They scream and we get escorted down an aisle between the screaming people. Someone says the hobbits came separately. They're coming round the back while we're coming in the front - we're a diversion.

They haven't opened the mall yet and inside there are tables set up with huge posters above them. One of the women who came with us in the limo is beautiful; I keep looking at her, thinking she probably plays some sexy vampire or something. She sits under a poster of herself with a Klingon crab-shell on her forehead. George Takei is there and the guy who used to be in Benson. Bo gets ushered under a photo of him as the Witch King, it could be anyone. I say, 'Have fun' and they sit the albino twins from the Matrix 2 on one side of him and Pussy Galore on the other. Then they open the doors.

The idea is that ordinary people buy a photo of the famous person of their choice then get that famous person to sign it. Ordinary people are allowed to take a photo with the famous person as well, so long as the queue's not too long. About ten minutes in they announce they are virtual-queuing for all the hobbits and Giles. I ask someone and they tell me virtual-queuing is when you're given a number and sent away and they call out the numbers over the mall loud speakers - it keeps the mall clear so if there's a fire or mutant rebellion people will be able to get out. I start thinking about Dawn of the Dead. The other friends and partners of famous people seem to know what to do while their famous friends and partners are signing photos and having photos taken. They go shopping and get their hair done and read books in Starbucks. The former child star's wife sits next to him the whole time, rubbing his back. Bo's line is pretty long. He's talking to the guy from American Werewolf in London. The twins are wearing sunglasses. They tell Bo it's because of the flash photography. I have another opinion. I take a walk around. I see the oak. They built the mall around the oak. I find a grocery store and buy some lunch for Bo and a coffee. I ask one of the security guards to give the coffee to 
Bo and Bo smiles and the security guard says, 'Sorry, no drinks from fans. They have drinks.' I say, 'Oh, cool,' and shrug at Bo.

There are a lot of people dressed in long black coats and others dressed all in white with fangs. I sit down and watch it passing me by. A woman sits next to me, I say, 'Hi - are you having a good time?' She is beaming, 'Hell yeah.' She has a child with her, a girl of maybe three. The woman has lupus. I'm sorry to hear that. She says when she was really sick and pregnant she couldn't move from the couch and she watched every episode of Buffy the Vampire Slayer. 'Giles saved my life,' she says. I say, 'Neat.' She is so excited to see Giles, she's virtual-queuing for him. They're calling 75 - she has 149 . I say, 'What do you think your chances are?' and she says, 'Pretty good.' She says neither her nor her daughter would be here if it wasn't for Giles. She took out a $£ 500$ personal loan so she could see Giles. She can't wait to shake his hand and she's talked to the security guards about having a photo of him with her daughter. They said she would have to wait and see. She leaves to go and see Buffy's gay friend. I start talking to other people, a lot of them say, 'New Zealander!' and I smile and say yeah. I start to feel a little famous myself. I say, 'Oh, I'm married to the Witch King.' And most of them are pretty impressed.

Around lunchtime, I take a walk outside and talk to a bus driver about catching a bus to Bletchley Park. He suggests I take a cab. He says I really want to go on Saturday. On Saturday everyone dresses up and they have a fashion show and bring out the Enigma machine, or a replica of the Enigma machine, because the original went missing. He says they have old cars on Saturday so I decide to wait because I wouldn't mind seeing some people dressed up.

I watch Bo for a while. People come up, he signs their photos and stands up with them for a photo, over and over again. A lot of them go, 'Wow,' and giggle when he stands up. Some of them tell him he's really tall. When they close the doors, he comes out from behind the table and says, 'Those twins have got something about the sunglasses and the flash photography.' I say, 'Only two people wear sunglasses inside - criminals and wankers.' He has stuff with him. 
Some Germans wrote him a poem. Germans like him. Some girls from somewhere knitted a scarf for all the hobbits and him. 'There are some pretty weird people here,' I say combing my fingers through the fringe of the scarf. 'Some pretty weird people who paid for our trip,' he says. He's right. I tell him I'm going to Bletchley Park on Saturday and that I can't catch a bus. He finds this hard to believe but I tell him a bus driver told me.

There's a panel that night at a movie theatre. The famous people are going to sit on stage and answer questions and then they'll play the movie, but not before the famous people leave because they've already seen the movie. I can't go because it's sold out, completely, even the aisles. I find myself in a bar, in a multiplex, in Milton Keynes with hobbits and Bo and Sauron and the other Ring Wraith. Bo says, 'Just be cool, eh?' I am not cool again and giggle a lot and eventually just sit in a corner. The panel goes well. Bo says they asked him what movies he was working on now and he said, 'None, I'm a Librarian,' and people laughed. The hobbits want to go out for a Thai meal. Milton Keynes has one Thai restaurant. We want to go home. We ask if we can go home. I've had enough of the whole hobbit road show. Every now and then I look around and all the hobbits are scruffing each other's hair and jumping around and laughing and I think when I was kid and all I wanted was to be was special I would have loved this.

The next day is the same as the day before. I find more food. We don't have a lot of money so I can't go shopping. I sit and watch the people and watch the hobbits. The kid from Star Wars arrives - another Kiwi - he's a bit of a shit and is trying to 'pull the birds' as my dad would say. Bo and I say, 'Dead, hey dead there's someone at the door,' behind his back and slap our knees at how funny we are. I talk to another bus driver who points to a timetable and says, 'You want to catch this bus here and get off it at the indoor ski field, then get on this bus, and the Enigma's not missing it was returned. It's only some bits that are missing.' It sounds bloody confusing but I tell Bo I think I'll give it a go. It doesn't feel like anything can go too wrong in Milton Keynes on a Saturday morning. That night 
they close the indoor ski field to the public so the hobbits and Boba Fett can go snow-boarding.

The bus thing is confusing. All the time I'm waiting I'm asking anyone who's around if this is the right place for the bus to Bletchley Park because I panic when I'm waiting. When I get to Bletchley I have to walk from the town centre. Everything is shut and covered in graffiti like a ghost town - like everyone moved to the mall. I walk down a long, tree-lined lane and at the end there's a sign saying 'Bletchley Park - National Codes Centre.' I pay at the ticket booth and they give me a map and a sticker saying, 'Station X.' It's everything I hoped for. I follow the arrows that lead me into the huts and out into the sun and back into the huts. Turing's machine has a room of its own. There's a mannequin standing beside it in a white shirt and a black skirt. She has high-heeled, lace-up leather pumps on and her hair is in Victory rolls. It's a beautiful machine. He has made a beautiful thing for war. I read all the cards on the wall beside Turing's machine. None of them say 'gay' or 'court-sanctioned chemical castration' or 'courage under abject cruelty.' They say nothing about injustice and a lot about the glory of the British way of life. I stand back from the cards and take photos of the machine. I take photos until so many boy scouts arrive that I can't take a photo without boy scouts in it.

The last hut is a computer museum. One of the computers has a cassette deck attached to it and I remember the first time I saw a computer and how it had green writing on a black screen. I remember an ad in my mother's magazines, with a tall skinny woman in flares smoking a long cigarette. It said, 'You've come a long way, baby.' The boy scouts arrive and start playing Pong on the Atari and more than one of them says, 'This is dumb.'

In the mansion there are photos. Army huts, army vehicles and, standing beside them, all the people no decent person wanted to depend on in wartime: people who did crosswords in twelve minutes, homosexuals, pacifists, communists - smart arses. A lot of them look sick and weak dressed in their army uniforms smoking. None of them look like they want to be there but all of them are. 
In the sun, in the mansion gardens, it looks like every Bletchley local is here, dressed up. There's a policeman on a bike and women and children milling around. There are no soldiers and I'm not sure how many communists or pacifists. I buy a couple of aerograms with messages in code and post them in a 1940s post box. There's an announcement that the Enigma machine will be on display in an hour and a half. I decide I can't wait for an hour and a half and get back to Bletchley to catch the last bus, so I buy a postcard of the Enigma machine and leave.

I catch the last bus back to Milton Keynes and the mall. I sit in the mall under the oak and read the brochure from Bletchley Park. The loud speaker says the mall is shutting in ten minutes. I meet Bo, we get into a limo and go back to Fawlty Towers. The driver passes back an autograph book and says it's for his daughter. I'm the only person in the car who isn't famous. Someone from Star Trek says, 'You should sign it anyway,' because not being famous is kind of special in a car full of famous people.

Some of them are going to another convention in Scotland, another mall. Bo and I are going to Paris, on a train where no one recognises him. We get a room on the top floor of a hostel. If you lean out the window you can see the Eiffel Tower. Bo leans out the window and tries to take a photo of himself and the Eiffel Tower but his head gets in the way. That night, before it gets dark we sit by the Seine and watch a small dog play with the body of a headless pigeon. 'Alan Turing killed himself with an apple,' I say to Bo as we watch the dog, 'sort of like Snow White.' 


\section{THE START OF SOMETHING FOR ME}

\section{THEY'D PROMISED IT TO THEMSELVES for their}

sixtieth birthdays. Sitting at their best friend's wake, two years ago in Westport, they drank to it. Sue and Carol had spent their whole lives looking after people: men, children, more men, then their parents. It was their time. It felt like a magical place. They'd waited long enough for someone else to take them there. They would take themselves, each other.

They researched everything. Sue had a friend and from there it was all on the net. The doctor who did the operations worked in Glasgow before he came to Malaysia. Sue emailed Carol a link to his credentials, which were on the tour company's website. Above the link she wrote, 'Looks good.' Carol agreed. The doctor had a statement on the website saying that his work with the tour company meant he could do pro bono work with burn victims. 'Poor Malaysian people, who can't afford it,' Carol said on the phone. Sue said, 'Yeah,' and took a drag of her cigarette. 
They both agreed it was vanity. They said it to each other often, 'I know it's just vanity.' They saved, but when the time came Carol hadn't sold the house and for a while it looked like the whole thing would die in a ditch. At the last minute, Sue found some more money and said she would loan it to Carol until the house sold.

Carol told her daughter, Amy, that Sue had shouted her a week at a health spa in Sydney for her birthday. Amy said, 'Cool, sounds luxurious.' Amy had never been to a health spa. Carol doubted Amy had been to a hairdresser in the last year. Carol pushed Amy's hair back from her face as they were saying good-bye. Amy looked toward the road and said, 'Mum,' in an annoyed way and pushed her hair back again.

When they got to Auckland, Carol sent a text to Amy, 'More surprises we're off to Malaysia.' Amy wrote back, 'Have a great time.'

'Kids,' Carol showed Sue the text, 'they don't give a shit about anyone except themselves. I could come back with one leg and I'd have to point it out. But if she wants a baby-sitter?' she rolled her eyes. 'She's all over me like a rash.'

Sue said, 'Yeah.'

'What did you tell Mike?' said Carol.

'I left a message saying I was going to Asia for a shopping trip.' Sue's boyfriend Mike had a wife and a family on the Shore. 'He didn't reply.'

They flew direct to Kuala Lumpur. The heat hit Carol as she stepped off the plane. It was like a wet hot blanket which wrapped itself around her. She started sweating and fanning herself with her immigration forms. A shuttle was waiting at the airport to take them to the apartment. 'It's beautiful,' Carol said as they walked beside the pool to their room. 'It's like some mythical Greek island.' There were only women. Everywhere they looked, women in white robes and surgical dressings lounging on deck chairs under the smog-filtered heat.

They met with the surgeon that afternoon. Sue wanted everything: face-lift, eye-lift and botox. Carol said she just wanted a sharper, more defined chin and less 
baggy eyes. They asked to be in the same recovery room after their operations. The next morning they were taken by shuttle to the hospital and given premeds. Carol felt groggy as they wheeled Sue out - groggy and hot. Despite the air-conditioning, the hospital room was heavy and warm. Two nurses came and wheeled her to theatre. The anaesthetist asked her to count back from ten and everything went black.

Carol came to in a room that seemed green and still hot, her jaw ached and her eyes were covered with swabs. She heard a moan and whispered, 'Sue?' There was another moan. A nurse came, put a buzzer in her hand and said, 'Ring for pain relief.' They laughed slightly at her accent, then moaned and spent the night lying completely still, pushing their buzzers every couple of hours.

The next morning they were discharged, and the shuttle took them back to the apartments.

'I feel surprisingly good,' Carol said.

'Mmm,' Sue said, holding a cigarette up to her swollen lips and leaning out the window over the balcony.

The door bell rang after lunch and two girls entered with towels on a trolley. One of them said, 'We wash you.' Carol looked at Sue, who shrugged her shoulders.

Carol lay back in the huge white bath while the girls washed her. They finished by washing the blood from her hair. 'Glorious,' she said to them.

After their baths, Sue and Carol had massages and pedicures. Two more girls came to their room and while one filled their fridge and fruit bowls, the other changed the flowers. A nurse came to check their medication and sutures. She said everything looked good.

Later that night, they sat on their balcony and looked over the city.

'I could get used to this,' Sue said.

'It's so spiritual,' Carol said. 'Revitalising, energising. It's such a positive, woman-focused space.' 
Sue nodded.

'It's like they've been watching me all my life, saw what I needed and put it all here for me.'

Carol woke to the sound of sobbing. She looked at the clock beside her bed, it was two in the morning. Her face ached and felt large.

Sue was standing looking at herself in the bathroom mirror, the bruising had come up.

'What have I done?' she said.

'It's okay,' Carol squinted at her own face. A yellow-purple bruise covered her throat and stretched up both sides of her jaw. 'It's just bruising - it's part of the healing,' Her eyes were almost shut.

'I look like Frankenstein.'

'We both look like Frankenstein,' Carol said in a supportive way.

They both laughed a little.

'We can do this,' Carol said. 'We've had babies.'

They laughed a little more.

'I'll make a cup of tea,' Carol said. 'We'll have a massage in the morning.'

The next morning they put on sunglasses and white hotel robes and went to the pool. They met lovely women lounging on the deck chairs. Secretaries, sales reps and a pilot. Cathy had had the yummy mummy package; she said she just wanted her body back. Carol said, 'Oh I relate. They suck the life-blood out of you.' Donna had had breast augmentation. She'd been waiting three years but could never afford it at home. 'It's so reasonable,' Carol said, 'and luxurious.' The women nodded and said, 'Mmm,' and 'I know,' like it was ridiculous how reasonable and luxurious it was. All through the afternoon girls brought them drinks and snacks. Sue asked one of the girls what the time was, and when she said one-thirty some of the women got pills out of their bags and took them. 
The swelling went down and the bruising and the stitches came out. Sue, Carol and Donna went shopping, and to a temple. Sue bought new jeans and new tops. Carol bought Amy a head band and some jewellery on her credit card.

'It's so good to be doing something to help such a spiritual place,' Carol said to Donna, smiling at the small children who sat on the temple steps.

Donna said, 'I feel like this is the start of something for me. I know it's just vanity, but I feel like something's coming back to me that I lost a long time ago.'

'It feels so good to have finally done something for myself,' Carol said. 'Something nurturing. There she is,' Carol waved to Sue, who was sitting outside the temple in her sunglasses and head scarf, smoking a cigarette. Sue waved back.

They went out to dinner that night. Carol wore a scarf around her neck; she hadn't been able to totally cover the remains of the bruise with make-up. Sue went to the bathroom and was there a while. 'I'll just go and check her,' Carol said to Donna. She found Sue standing in front of the mirror in the bathroom, holding her hair up, turning slightly to one side then the other. She smiled at Carol in the mirror, 'I'm going to tell Mike to get fucked.'

'Good on you,' said Carol, 'You look great.'

'I do,' said Sue.

'Let's drink to that,' and they hugged each other and went back to the restaurant.

Carol called Amy from Auckland.

'Check this out,' she said to Sue as the phone rang.

'Amy? It's me - oh, Lyra, get mummy, darling, hello, yes, get mummy, yes, Nana loves you, too, get mummy.' Carol raised her eyes at Sue, who laughed. 'Amy, hi, Carol here. Yeah, good. I got a bit sick, though. Yeah. It's not very clean there - a bit primitive, yeah. Stomach bug, yeah. Yeah. On the upside I've lost about ten kilos. Yeah. Yeah, I look like I did a couple of years ago. Yeah, I know, great. Yeah, you should go.' Sue laughed, Carol almost did, too. 'Yeah, no, I'll get a 
taxi - just want to rest - I'll see you in a couple of days. Yeah, bye. Love to Lyra.' She flipped her phone shut and Sue hugged her and they laughed.

'You devil,' Sue said.

'Well, she probably won't even notice, but just in case. I've been working on it for days.'

A week after arriving home, Amy called Carol and asked if she could baby-sit; Amy had a work lunch. Carol said fine, when did she want to drop her off? 'Could you come to my place?' Amy said. 'I'll make lunch.'

Amy met her at the door and said, 'You look amazing.' Carol gave a little twirl and Amy said, 'That place really agreed with you. You look amazing.'

'I feel great,' Carol said. 'I feel young. I feel your age.'

'Well, you look great,' Amy said. 'Lyra's in the garden. I made soup for lunch, there's some bread in the freezer.' As she walked down the path she turned to look at Carol again and they smiled at each other. 'I shouldn't be long.'

Lyra ran her ragged. They dressed all the dolls then undressed all the dolls, danced and sang, then went to the park where Lyra wanted to play tiggie and didn't want to leave. They walked the whole way back with Lyra crying loudly and pulling so that Carol had to drag her. Amy didn't get back until four.

When she got home Carol looked at herself in the full length mirror that hung on the wall of her bedroom. She had stains all over her silk top, her fingernails were full of mud from the park and she hadn't put any lipstick on for hours. She sat on her double bed and took off her shoes and socks. She wished she'd stayed at Amy's for dinner. It was rowdy there; Lyra running round shouting and laughing, Amy's music up too loud. Her house was peaceful. She walked to the kitchen and looked in her fridge. She'd have a salad then call Sue talk about her week, plan something for Easter. Maybe they could go to Tauranga, where they met when the kids were young. 


\section{FOR CHRISTMAS}

\section{IT WAS NEARLY TEN O'CLOCK on the Saturday night}

before Christmas. Mary sat at her desk looking at her computer screen. The light above her cubicle was the only one on. The rest of the floor was in darkness.

She'd started a publish at two that afternoon. It took five hours to get new content onto the test site. She'd gone to a costume party at seven. She thought she would just be popping in to work to check the test site and push it to live, but now sat looking at the report on her screen. The publishing system had deleted a thousand pages off the test site and the number was flicking over higher and higher as she watched: 1,207, 1,245, 1,269. There were about nine thousand pages on the ministry's website. It would stop soon, she thought - she'd been thinking since the report read 800. Mary looked out the window then back at the screen 1,503 - it would stop soon. She'd call technical support when it got to 1,700, maybe 2,000 . She looked at the time, ten fifteen. She didn't want to call tech support at ten fifteen on a Saturday night. The ministry outsourced maintenance of the 
publishing system. The manager looking after their account had said, 'Day or night.' She put on her headset and rang tech support. The way things were going

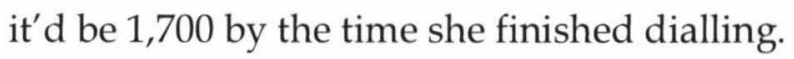

'How many?'

'Simon, hi, sorry to ...'

'How many?' Simon said.

$' 1,712 \ldots 13 \ldots 14 \ldots$...

'Hilarious.'

Mary heard Simon shift from his chair and walk to another room.

'What's gone?' he asked.

Mary scrolled through the report. 'All the legislation, most of the forms and all the letters off the internal site.' She watched as Simon stopped the publish and the report slowed, then stood still. '1,812,' she said.

'We have a winner,' Simon said.

'It's getting worse.'

'Ya think?' Simon said, then, 'Damn,' under his breath.

She heard typing and mouse-shifting and began to swing in her chair.

'Did you go as Gabrielle in the end?' Simon said.

'Yeah.' Mary picked at the silk Greek-style dress she was wearing.

'Feathers or cellophane?'

'Feather ones.' Mary looked at the wings on the chair beside her.

'Very Victoria's Secret.'

'Yeah, without them I kind of just look like Jane Austen. There were three of us.' There was silence over the phone except for the typing. 'Gabrielles.'

'Did you have an archangel cage fight?'

'Don't get weird,' Mary said.

'You better get a cup of tea,' Simon said.

'Is it going to take a while?' 
Mary padded to the kitchenette in bare feet, her long dress sweeping the floor and floating out behind her. It was warm in the building; the air conditioning was turned off on Friday at about midnight and back on at four o'clock on Monday morning. It made the whole place a new type of quiet. When she worked late she could tell time by the level of silence. It was wetter without the air conditioning. As the jug boiled she took hair clips out of her hair. She shook her head and glitter rained on the bench. Her hair stayed in place. The sign above the sink said, 'Your mother doesn't work here - wash your own dishes!' She heard her phone ring.

'How committed are you to this publish?' Simon said.

'Oh, that sounds like what I want to hear.'

'I'm just asking.'

'The changes have to be on the website by 8.00 a.m. Monday.'

'Or what?' Simon said.

'There could be some discomfort.'

'Yeah, but, no one's going to die,' Simon said, 'It's not brain surgery.'

There was silence for a moment.

'The CEO wants the changes on the site by Monday at 8.00 a.m.,' Mary said. There was more silence and the sound of Simon waiting. 'The CEO came down on Friday and said he wanted them on the site by 8.00 a.m. Monday.'

'Do you like your job?' Simon said.

'Not at eleven o'clock on a Saturday night, dressed as an angel.'

'Archangel.'

'Sorry, archangel.'

'I think I might be able to find a way of limping on.'

Mary looked at the ceiling, rows and rows of holes in tiles. 'With all due respect Simon, "limping on" is what got us here in the first place.'

'Don't go all "due respect" on me. Do you want a publish or not?'

'I want a publish without some huckery fix holding that publish together.'

'You can't have both,' Simon said. 
Mary looked out the window. A sled with reindeer flashed on and off.

'Then I guess I want a publish,' she said. 'I'm not manually republishing eighteen hundred pages, though.'

'Eighteen hundred and twelve,' Simon said.

'I'm not manually republishing eighteen hundred and twelve pages.'

'Nah. Just don't push it to live.'

'Ya think?' Mary said.

'Yeah,' he said sarcastically, 'because with all due respect, Mary, if you do that we'll lose at least eighteen hundred and twelve pages off the live site.'

Mary rubbed her face and more glitter came off in her hands. Simon started typing on the other end of the phone.

'Mary,' he said. 'Why didn't you go as Mary?'

'Should I leave you to this?'

'Nah, I need you to watch the report - I'm at home, I haven't got access to the report.'

'Home?' Mary said. 'I'm on the seventh floor of a corporate building on a Saturday night.'

'Don't jump off.'

'You didn't say Simon says.'

'It's implicit.'

Mary looked out the window. The city spread out, then stopped abruptly at the water, 'I'm going for a bit,' she said, 'I left my tea in the kitchen.'

'Tea,' Simon said, 'All right for some.'

'Get yourself a cup of tea, Simon.'

'Don't go far. I'll ring you.'

Mary pushed the end button on her phone and swung in her chair with her headset still on. The floor was running a 'decorate your cubicle' competition for Christmas. Her team hadn't started yet. They were all dealing with the cannibalising publishing system. Mary was a translator, the rest of her team 
produced content for the website. They went to people in the ministry, asked them what they needed, then wrote pages to go on the website. When there was a problem they came to her and she went to the technical people and explained their problem in technical terms. Then she went back to her team and explained the solution in non-technical terms. She looked at the box of business cards on her desk. They literally called her a Translator. People used to make things. She'd been brought in after a couple of altercations that escalated to written warnings, at least one of them addressed to Simon. Her boss, Robyn, said technical people weren't people-people, they were logic-people; communication was never a technical person's strength. Mary's main task was to talk to Simon, so no one else had to. He was the most difficult person in the technical team to deal with, because he was the one they relied on the most. For years he'd been cobbling together fixes to keep the publishing system functioning. By the time anyone realised this, he was the only one who actually knew how it was working. Simon displayed the arrogance of a loser. Mary imagined his mother saying things to him like, 'They're only jealous.' People disliked him.

It had all gone underground since the publishing system had started deleting content. People stopped hushed conversations when Mary approached them. It started slowly, so no one had noticed. Then complaints started piling in: broken links, call-centre staff unable to find content, then the minister's office. A few people, including Mary, knew exactly what was wrong; no one knew how to fix it. Everyone blamed Simon. There were rumours and conjecture and fingerpointing. It wasn't the first time Mary had been in the office late and alone - it wasn't even the tenth. The publishing system had always been an ugly, disfunctioning child that needed constant reassurance and direction. This was how she explained it to the rest of her team: 'You know Frankenstein's monster?' They joked about getting her an apartment in the block next door and making a trapdoor for her to crawl through in the night. Her team called the publishing system 'her baby.' Simon called it a badly deformed abomination he'd inherited from 
another company that knew nothing. He talked constantly about what he would have done differently. Mary listened, ate almonds and said, 'Aha. Yip. Aha,' and when he was finished asked if he could do something for her, when he said yes she'd make a joke with him and they'd laugh. People who didn't understand her job thought Mary was Simon's friend.

Her phone rang.

'Simon,' she said.

'How'd you know it was me?'

'Everyone else I know is at a party,' Mary said.

'There's something wrong. I can only find one page altered.'

'Yeah,' Mary said, 'that's okay.'

'Eh?'

'We're only altering one page.'

'We're deleting eighteen hundred documents...'

'Eighteen hundred and twelve.'

'We're breaking the publishing freeze to alter one page?' Mary could hear him scrolling.

'The home page?' Simon said, 'We're breaking the publishing freeze to alter the home page?'

'How's the fix going?'

'It's a Christmas message.'

'I've run out of almonds. I'm ready to go home.'

'It's a Christmas message from the CEO.'

She could hear Simon leaning back in his chair.

'Out of almonds, Simon.'

'Merry Fucking Christmas,' Simon said.

'I'm not talking to you about this, Simon. I'm talking to you about the fix and that's what I'm talking to you about - and almonds.' She started looking through her drawers for more almonds. 
'It must be great working for the public service, Mary - standing up, making a difference,' Simon said. 'Now, as an employee of an evil multi-national corporation I don't care what it is I'm doing at eleven o'clock on a Saturday night, it's all money to a bread-head like me, but you, Mary, look at you, you're really making a difference.'

'I am literally squeezing a stress-ball, Simon,' said Mary. 'You have reduced me to cliché. What's happening with the fix?'

Simon hung up.

No one in Mary's family understood what Mary did for a job. They understood the translating thing, but they weren't sure what it was all for. What did she do? She tried to explain it was like management and her father said, 'Oh, so you're a manager?' and her parent's faces lighted a little. She said no, she wasn't anything like a manager - it wasn't like management. She would get excited sometimes and ring her father and say, 'Check out the site, there's new stuff on the website.' He liked music and pictures. A few months ago one of the Comms team had brought up an armful of t-shirts. They were cleaning out the cupboard, did anyone want a t-shirt? The t-shirts said things like, 'Get moving,' and 'Move it or lose it.' They'd been printed for the ministry's team in the Corporate Challenge. Three hundred public servants walking and running through the streets of Wellington to show a commitment to work/life balance. Mary had sent one of the t-shirts to her father. Every time she talked to him since, he said it was the best t-shirt he had. He was wearing it to the gym; could she send him another one? It was such great cotton.

The phone rang within the half hour.

'I just thought of something,' he said, 'I wonder if you can help me out with this, I think I have it straight. So we're not breaking the publishing freeze for the Select Committee information to let people make informed submissions, but we are breaking it for a Christmas message?'

'Wearing thin, Simon,' she said. 
'This must irk you, Ms. Mary.'

'It has Santa on it,' said Mary, 'How could anything with Santa irk me.'

'Your Te Reo resources can't go up - but a Christmas message can?'

'PC gone sane, Simon. What can I say?'

'Your job sucks,' he laughed and hung up.

It was his fault. She tried to be nice and say, 'Oh, no maybe it was us. We push the publishing system so hard. We were bound to break something eventually,' but it was his fault. All his dodgy fixes had made the publishing system eat itself and when he said, 'Yeah, it was probably you,' she was pretty sure he knew it was his fault.

Ten minutes later, he sent Mary an email saying 'Tin a cocoa. Tin a cocoa. PC never looked good on you.' This was how he tried to secure her allegiance. It was like he watched other people being friendly, tried to replicate it and got it all wrong. 'We're like the odd couple,' he once said to Mary. 'You're a liberal and I'm a realist.' She drank cold tea from her white mug and thought, this is my job.

On Friday, Robyn had asked Mary to join her in the General Manager's office. They'd explained the CEO's request and asked if she could organise it. A month before they'd promised her a publishing freeze until the New Year. No new content going on, no old content coming off, so the technical team could concentrate on fixing the problem. Mary took notes in her hard-cover book and said, 'Yeah, sure.' Robyn had faith in her completely; this meeting was for the benefit of the General Manager. The website was making him look bad. Mary had closed her book and, looking out the window, said, 'There are risks.' The General Manager had said, 'I don't want to hear about risks I just want it done.' Mary stood for the website and all the things about the website he didn't understand. All the things he didn't understand were the things making him look bad.

The phone rang. 
'Happy Holidays.' She imagined Simon, sitting in his office at home, doing whatever he did, suddenly thinking of it and saying to himself, 'I must share that with Mary. We like to have each other on. That's what friends do.'

'Simon.' For all she knew the fix was finished and he was pissing about.

'Isn't that what you liberals say?' Simon said. 'It says "Merry Christmas" you know, Mary? Isn't that a bit denominational? There's a picture of Santa on it.'

'And a small robin holding a sprig of holly.'

'Do you want to call the PC Police or shall I?'

Suddenly she didn't feel like being nice any more.

'Simon, you don't seem to be getting much done towards this fix - shall I call Robyn?'

There was a pause.

'Robyn's in Hawera,' Simon said.

'It's okay, I've got her cell phone number,'

'Give me half an hour or so.' Simon hung up.

Mary took off her head set and said, 'Fuck you,' to the phone. She flicked the space bar of her keyboard with her index finger. She could push the test site to live and destroy the whole website - she could say it was an accident, it was late, Simon was annoying - she warned them. She could have asked a question in the General Manager's office. She could have said, 'The risk out-weighs the benefit.' She could have said, 'I feel uncomfortable with this.' She could have said, 'This is crazy.'

The cubicle across the floor, Actuaries, was decorated with sand, towels and a tent. The banner above it said, 'New Zealand Christmas.' Human Resources had fastened white fluffy snow to everything. They had a snow man in the centre. The lawyers had cut out paper to make some sort of Santa's grotto. People used to build things for a living; her father built houses. She lay down on the couch outside the General Manager's office and read a women's magazine she'd found on his 
PA's desk. Her phone rang at 1:45 a.m. She let it ring, then walked slowly towards her desk, still in bare feet, dress floating behind her.

'I thought you'd gone home,' Simon said.

'Courtney Love's in rehab,' she said.

'Robert Downey's out.'

'Wow, is it, like, 1995 at your house?' Mary flicked through the magazine. She was the boss now.

'It's done,' said Simon. 'You can run the publish again. Have you still got it all in the profile?'

Mary moved her mouse and looked at her screen as she stood behind her desk, 'Um, yup.'

'Okay, start the publish. Merry Fucking ...'

'Simon, you've done that one already.'

'You can go home,' he said. 'Come back in the morning and push it to live.'

'Yeah,' Mary stretched. 'I'll call you if there are any problems.'

'There won't be any problems.'

'Have a good sleep Simon,' she said. 'Talk to you tomorrow.'

'Hopefully not.'

'True story.' She picked up her wings from the chair beside her.

'See ya,' Simon said.

'Thanks.'

The next morning when she came in the test site was intact. She emailed Simon to say, 'All well', and pushed the test site to live. On Monday afternoon identical boxes wrapped in identical ribbon were delivered to every staff member on Mary's floor. There was a card in each box saying 'Thanks for your good work,' and the ministry's stamp. One of Mary's team said, 'Oh look, it's like the whole ministry's wishing us Merry Christmas.' The box contained a beach towel, some sun-block and, a torch with an alarm and an AM/FM radio. 
'What's the handle for?' Mary said, playing with the small, black handle on the side of the torch.

'You can wind it up to charge it,' Robyn said, 'It's for your survival kit at home.'

Mary wound the handle and it made a whirring noise. 


\section{AN IN-JOKE}

\section{THERE IS NEVER AN OPPORTUNITY to say the things}

to her that I want - unless she dies. If she dies all the things I want to say to her I will say about her at some funeral or memorial service. She's inspirational. A man in a meeting says, 'These are only sentences,' when he's asked to share and waves at the pages of a book he has open on his lap. 'Words,' he says and makes a face in disgust. He has felt the touch of Jesus. His psychiatrist calls it The Christ. The walls moved, circled then closed in on him and he felt a darkness. 'But not suicidal,' he says. I imagine it written in his medical notes The Christ with a capital $T$ and a capital $C$ in bad doctor handwriting.

She is a friend beyond comparison. Another sentence. A woman who held me when I cried and laughed like we couldn't stop. There are greeting cards for this. I'm trying to write her a letter and it's coming out dreadful, awful. She rings and I'm busy and I forget to call her back. 
She puts out the washing and cleans when I visit her. Her housekeeper is sick. She didn't realise until yesterday that no one had been to clean the house. Her son asks if there's any food. 'If you clear away that bench,' she says, 'I'm sure you'll find something under all those papers.' We laugh. We've laughed a lot. We've talked a lot. We used to lie around for days at her house, talking and laughing and listening to meditation tapes. I said, 'Did that guy on that tape say something about Dalmatians?' She's asleep. We ate, as much as we could and when we ran out of food we made more food and went swimming. We didn't wait an hour. We had trouble finding an hour between when we finished eating and when we started eating again. We scraped mould off things and ate those. We sucked marrow out of chop bones. In the morning we'd put whole oranges and apples in a blender and add seaweed which made it all green. One night when I was at her house by myself I didn't sleep. He'd told me it was over and I couldn't sleep after that. I couldn't stop thinking about the last time and the next time. I was house-sitting. House-sitting was the polite term we used every time I got kicked out of wherever I was staying and didn't have anywhere else to go. She lived in a women's community that used to be a motel. When we first got clean a friend of ours parked her house truck in the space where the swimming pool used to be. Then someone killed themself in the house truck; hanged themself, holding their feet up while they died because they were too tall to hang free. We agreed it showed they really wanted to go - really.

The draw-cord in my daughter's sweatshirt comes out of the hood of it. She's pulled it and now it's come out in the wash. Her father threads it back as he kneels on the floor of his mother's house which used to be baches. It was converted from three baches into one house. There's an open fire. I say, 'Sometimes it's easier if you use a safety pin to thread it through - so you've got something to hold onto.' He uses a pen and the pen gets stuck on the small clip that's designed to hook it to your pocket. He says, 'Oh, well, that's working,' meaning the clip on the pen. We both laugh. I make spelt flour vegan pikelets which look awful and taste bad. We 
give them to our daughter and listen to Willie Nelson who we both call Wylie Nielsen - it's an in-joke. 


\section{THE SHIT WOMEN TALK}

\section{THERE WERE SEVEN INMATES AT THE AA}

MEETING and three women from AA on the outside. The women from outside wore coats with keys in their pockets. They folded and unfolded their visitor's slips around their driver's licences. It wasn't church. Church was on Wednesdays but one woman spoke at a time and none of the inmates spoke for long. The first AA woman talked about being in her own personal prison when she was drinking and how AA set her free. After she finished, Poppy asked to be excused to go to the toilet. The AA women smiled and nodded. There was one guard covering the whole wing and the AA people asked that they didn't come into the room for head-counts because it was anonymous. The prison social worker agreed and the guards were instructed just to check from the window in the door occasionally - to make sure no one was hurting anyone else. 
Poppy shut the half-door of the toilet stall and sat against it. She closed her eyes and listened to the hum of noise far enough away to be nothing. Prison was a noisy place. There was always talk - the shit women talk - over and over, for years and years: they didn't do it, their kids, their kids being molested, their kids in CYFS care, their kids being molested in CYFS care, Jesus, dreams, stand-overs, TV, boyfriends, girlfriends, who's holding, losing things, swapping things, parole, excuses, no parole.

'Poppy?' It was Slade, looking over the stall, 'Poppy - all I'm saying is if she's been transferred, why did she get sick so fast?'

'And all I'm saying is stop saying it to me,' said Poppy, standing up.

'It makes sense.'

'Slade - with all due respect and without any desire to get involved - it sounds paranoid.'

'She's a narc.'

'She's hanging out,' her voice began to wine.

'She's a cop,' Slade said.

'Then tell someone.'

'I'm telling you.'

'What do you want me to do about it?'

Slade didn't know.

'What do you think you should do about it?' Slade said.

'Nothing. I'm going back to AA.'

They were reading the book when Poppy and Slade got back. The meeting took an hour. At the end they all held hands, said a prayer and the AA women hugged everyone and left. The guard came to take Poppy and Slade back to their cell and lock them down for the night.

As they walked through the door of their cell Slade said, 'You're wrong,' in a way that only Poppy could hear. Grace was lying on the camp stretcher. 
The cell could fit one inmate comfortably, two at a pinch. Poppy had been in prison for ten years, five of them in this cell with Slade. Then, two weeks ago, the maintenance team had brought a camp stretcher and Grace had arrived, carrying her plastic bag. She said she'd been transferred from a prison up north. She started sniffing and coughing and shaking about three days in. Slade watched a lot of TV. She didn't believe Grace had been transferred from another prison. Slade was convinced Grace had the flu and if she had been transferred from another prison she wouldn't get the flu. 'Immunity,' she said. It was straw-clutching to say the least. She'd been explaining it to Poppy for a week and each time she explained it Slade became more convinced of it. It was crazy. Neither Poppy nor Slade was anyone. Poppy had been someone but wasn't now. Slade was someone on the outside but not here. Slade was mad and Poppy was tired.

Grace coughed.

'You need to cover your mouth when you cough,' Slade said. No one said anything else and the lights went out. In the dark, women shouted goodnights to each other across the wing. Someone sang. Someone cried. Toilets flushed. Grace covered her mouth and coughed.

The next day two jobs came up in the sewing room. Poppy was given a second chance and Slade was offered the other job. When she briefed them, the supervisor said Poppy would have to start on the screen printing because she needed to build trust again after last time, with the machines and the scissors.

They made grey marl sweatshirts and pants for the men's prisons. Poppy screened CORRECTIONS DEPT in black over and over again on the backs of the sweatshirts.

Lunch was one creamed corn sandwhich and one luncheon sausage sandwich wrapped so tight in glad-wrap the white bread was almost dough again. On the way back to the cells, Poppy swapped her luncheon for a corn with a 
woman who owed her money. That woman swapped it back for a corn with a woman who knew her mum. Slade caught her up.

'Didn't think you'd ever get back in the sewing room eh?' said Slade.

Poppy looked at her sandwiches.

'Lucky,' said Slade.

'You want corn?' said Poppy.

'Us both - imagine that? Out of everyone here, we get a sewing job,' Slade said.

'Corn's my favourite but you can have it,' Poppy said.

'Leaving Grace alone in the cell sniffing around.'

Poppy held out the sandwich and looked at Slade for the first time.

'Oh - go on then,' Slade took the sandwich, 'You want luncheon?' Poppy shook her head.

Back in the cell they watched Dr Phil and Grace looked sicker than yesterday. Slade didn't say anything.

'You been to the nurse, Grace?' Poppy said.

'Nah, I'm just hanging out.' Grace looked at the TV.

Poppy looked at Slade to say, see, she's not sick, she just needs drugs.

'Yeah,' Grace added, 'one of you couldn't put me right on that, could you?'

Slade looked at Poppy to say, see, she's a narc pretending she needs drugs but she's sick. Slade said to Grace 'We wouldn't know anything about any of that.'

Grace shrugged. 'Oh well, maybe I'll come to AA with you fellas next week.'

'Don't ask again,' Slade said.

The door opened, it was the twelve-thirty muster.

'Brown?' the guard shouted.

'Miss.'

'Durham?'

'Miss.' 
'Fields?'

'Miss.'

'Fields, you need to get those clothes off the floor.'

'Yes, Miss,' said Grace.

She hauled herself off the stretcher, picked up her clothes and put them in her drawer, saying 'Fucking screws.'

Poppy laughed, 'It's not Bad Girls, Grace.'

'It's all right for you. It sucks here.'

'It's prison,' Poppy said.

'It's boring,' Grace coughed and coughed and spat and shut up.

'I'm onto you,' Slade said.

'What?' said Grace.

'Nothing,' said Poppy.

After lunch a guard took Slade and Poppy back to the sewing room. Poppy wondered, by two o'clock, how many shirts would equal enough trust to get her back on a machine or cutting or anything that wasn't screen printing. She tried to listen closely to the noise of the sewing machines as they fell into a rhythm of distance; a sleeve, a neckline, a waist-band. She tried to follow enough of them for a continual hum. Then she tried to pick out just the high part so it stung her head. A woman bumped into her as she went past and said, 'Watch out, Poppy Tea,' like she was looking for a fight. If she was, it was with the wrong person.

At four o'clock everyone from the wing was let out in the yard for an hour. Poppy smoked and read a book in a corner away from everyone. Grace slapped women's hands and talked shit. Slade ran round and round the tiny yard surrounded by fencing and razor wire. When Poppy looked up from her book to see where the sun had gone she saw Slade talking to a woman. The woman was someone; Slade was shaking her head and talking to her. 
One of the guards organised a volleyball game in the gym. The gym echoed and banged. The guard's keys rattled as she played and a couple of times her twoway radio fell out of its holster. Slade came over and raised her eyebrow to the woman standing next to Poppy on the court. The woman left and Slade took her place. Poppy raised her eyebrows at Slade in greeting. When they rotated to the base-line Poppy said, 'What was that about?'

'Taking care of business,' said Slade.

The ball came to Poppy and she batted at it. The woman in front of her dove and got it over the net.

'Someone knew what to do,' said Slade. The ball flew behind Poppy and bounced in. The diving woman yelled, 'Fuck!' and, 'If you're playing, Poppy, play. If you're not, let Grace play.' Grace heard her name and ran over, coughing. Poppy got the cigarette from behind her ear and walked to the door.

'Please, Miss,' she said, lifting the cigarette to indicate to the guard by the door. The guard let her back into the yard, shouting, 'Durham,' behind her.

At dinner that night, Poppy and Slade sat in silence. They ate off their trays looking at their food all the time.

'Something on your mind Poppy?'

'Nah.' Poppy shook her head.

Slade buttered a piece of white bread with a plastic knife.

'Just,' Poppy wiped her mouth with a serviette, 'just, things have been quiet for us for a while now, eh?'

Slade nodded.

'No trouble?' said Poppy.

'What's your point?'

'Well, things are good like that - aren't they?'

'Are they?' said Slade.

Poppy shrugged. 
'From the days of John the Baptist until now, the kingdom of heaven has suffered violence, Poppy, and the violent bear it away,' said Slade, looking around as she spoke.

Poppy rearranged the plastic cutlery on her plate.

'They are bringing this to me,' said Slade. 'I can hear them - at night. This is just the last thing in a long-time test of me.' She lowered her voice. 'When I was out there they were everywhere. They put things in my teeth, they can monitor me everywhere. Grace is one of them and enough is enough.' Slade stared at Poppy. 'He told me I needed to deal with it.'

'Jesus?' said Poppy.

'Yes, Poppy - Jesus.' Slade leaned back and looked around again.

It was no use.

'I see your dilemma,' said Poppy.

'Do you?' Slade put down her knife. 'Because, to be honest Poppy, you've been a little disparaging.'

'No disrespect intended,' Poppy said.

Slade looked at her for a moment, 'None taken.'

Dinner was over. All the plastic knives were counted, all the trays were counted, and all the inmates were counted and walked back to their cells.

It happened in the gym a couple of days later. One guard was playing volleyball. The other was outside, sorting something out. Someone smuggled in hairspray, someone else had a lighter. Grace went up quickly. The fire alarms went off, then the sprinklers started. Grace screamed and screamed and guards came running from everywhere as the sprinklers rained down. No one saw anything and Slade was someone.

The wing was locked down and loss of privileges continued into the weekend. On Monday during lunch Poppy was taken from her cell by a guard who watched her put on a pair of orange overalls over her clothes then led her to 
the visiting lounge. In the middle of the huge empty room sat her mother and her lawyer, Warren. She hugged her mother and sat down. The guard stood behind them with her back to the wall.

'I told them I wouldn't leave without seeing you,' her mother said. 'It's ridiculous - it's a long drive.'

'It's prison,' said Poppy.

'Warren has some questions to ask and some papers for you to sign,' her mother said.

Warren asked some questions and she signed some papers then he excused himself. The guard radioed for another guard and Warren waited by the door.

‘How's Brendon?' Poppy asked.

'Good. I had some photos,' her mother patted her jacket pockets. 'I'll send them.'

\section{'Cool.'}

'Your father put some money in your account. Have you got enough cigarettes?'

'Yes, thanks,' said Poppy. 'Are you going away for Queen's Birthday?'

'No,' her mother looked around the room. 'Well, maybe, up to Taupo.'

'Nice.'

'Warren said you're back in the sewing room.'

'Yeah,' said Poppy, 'yeah. It's good.'

'You're lucky.' Her mother looked at her nails. 'After last time.'

'Yeah,' Poppy said, 'Unexpected.'

'Well, that'll be good for the money.'

Poppy nodded.

'And the boredom. Idle hands and all that.'

Poppy nodded.

They sat in silence.

'I'd better go,' her mother said. 
They both got up. 'Yeah,' Poppy said, 'Thanks for coming.'

'I'll send the photos.'

'Cool.'

'Might see you for Christmas,' her mother said.

'Cool,' said Poppy. 'Drive carefully. Say "hi" to everyone.'

Her mother sat down as the guard took Poppy to the door, unlocked it and another guard took her back to her cell. She took off the orange overalls and handed them to the guard. The guard closed and locked the door of her cell.

Slade was lying on her bed watching Dr Ken Agnew. Poppy said, 'Second opinion?'

Slade smiled and nodded, tapping the remote control on her chin. The camp stretcher was gone.

A month after Grace, Poppy was allowed back on the machines. She made her own mechanical whining to drown out the talk. Two new women started in the sewing room. One of them held the door shut while the other took Slade's eye out with the handle of a plastic spoon sharpened to a point. As the guards broke down the door, the one with the spoon threw Slade on the floor, looked at Poppy and said, 'Don't think we've forgotten about you, Poppy Tea.' The sewing room was shut for the afternoon.

Poppy was alone in the cell that night. She sat on her bed watching television and listening for the nothing behind the babble. As the lights went out and the television lit the room she thought about her disappointed mother making a cup of tea for her disappointed father. Her brother's birthday was in a couple of weeks. Her mother would make dinner. Poppy had no idea what they would eat or where anyone would sit at the table. She tried to remember the sound of her mother laughing. 


\section{A BAD WORD}

\section{BILLY, MIRABELLE AND I DRIVE DOWN FROM}

CHRISTCHURCH. We get to Bonnie and Eddie's at about four in the afternoon. Their son Jet runs to the door to greet us. We put Mirabelle on the floor; they stare at each other, then Jet runs away to his room. 'Kids,' we all say and hug each other hello.

That night while we're doing the dishes after dinner, on the outside of the window, which is wet and fogged with the heat from the sink, a white splodge appears. Eddie says, 'Is that snow, or is it that sleet?' We look out the window - it's pitch black and Billy says, 'Snow,' and we all agree. We go outside to watch it fall. 'It's like static,' I say, 'What about driving in it?' Everyone nods. The kids have a bath. Bonnie reads Jet The Tiger Who Came to Tea. I stand next to the heat pump every chance I get. I make up reasons to stand next to the heat pump that have 
nothing to do with being lazy and cold. We eat some more and go to bed, and the kids wake up all night with snow jitters.

When the sun rises the front lawn is white, and the driveway. The hills and the roofs of the houses are also white - like colour's been made illegal. We look out at the snow and some of us move from foot to foot to keep ourselves warm. I put my foot down wrong and almost slip, 'Fuck,' I say. Jet looks at me, 'That's a bad word.' Bonnie says, 'Jet, don't be rude.' We look out on the snow. Everything that was black yesterday is white today.

We decide none of us are going anywhere for a while. We start to see cars moving on North Street and people walking on the foot paths. I can't imagine what could be important enough to bring them out but people are walking on the foot paths. People die in this weather. They go out, slip over and freeze to death. We need food and Eddie needs to pick up a birthday cake for Bonnie from South Dunedin because they're not open tomorrow. It's a long way away and Bonnie will worry about him driving, so we mess around home for a while. Billy makes scones with baking soda. Jet likes them. Bonnie and Eddie made wontons from scratch and the sun starts to come up Craigleith Street. The snow melts in some places and not others. Eddie walks out to start his friend's car. Billy does the dishes, Bonnie plays with the kids and I stand by the heat pump.

Bonnie is training to be a dental technician. We used to work together in a library. She makes teeth and eyes. She hasn't made an eye yet but she will, next year. Eddie walks over the icy lawn and down the driveway, kind of kicking his steps, brushing the snow away as best he can before he takes a step - testing each step before he takes it. I've already been out and getting back up the hill was the hard part. It's a favour. His friend left the car here when he went on a trip. Eddie is walking down the icy driveway, slipping a little every now and then, to start his friend's car so the engine doesn't freeze. Eddie and Bonnie's car is on the street. There's no room for it in the driveway now. 
People who live here tell people who move here to put socks over their shoes. I have never put my socks over my shoes - I'm not sure it would work if I did. I always thought it was a joke, like, 'Gullible's been taken out of the dictionary.' I've fallen over a couple of times on ice - nothing serious. I've lost control of my car while driving badly, the consequences weren't bad, just the swing the back of it got - I put my brakes on - people tell people who move here not to do that if they hit ice. 'Go with the skid.' You can't see it, that's why they call it black ice. It kills people. Someone dies. They went into the river at Wanaka - in their car - the news comes out it was a Malaysian international student who Bonnie had heard of but didn't know well. I say, 'It's sad to die so far away from home.' It sounds like the sort of thing I'd heard people say when people died. I regret it immediately.

The church bells ring. All the snow is gone and it is windy and horrible. The kids play and watch the television a lot. We watch a lot of The Wiggles. It annoys me. In the afternoon Eddie and Billy go out, under the guise of getting food, to get Bonnie's birthday cake. Bonnie has two birthdays. She was almost a refugee then her uncle bought a fake birth certificate so she has two birthdays - her real one and her make-believe official one. Bonnie says don't worry about the food. I say, 'I'm hungry. Get more food.' After they go and it's just Bonnie and me and the kids I think about the thing I have to do. I don't do it. When they come back they say everyone is buying food - 'It's like Armageddon.' We laugh and eat chips and bread and oil - I hide most of my share from the kids. Billy goes for a walk. I complain because I've been looking after Mirabelle the whole time he was shopping but he still goes for a walk. Bonnie cooks, I check my email. Billy and Eddie forgot coconut milk. I say Bonnie should text Billy to get it. He goes to three shops in the freezing cold but no one has it.

We eat the curry without coconut milk. Billy cooks poppadoms and makes the smoke alarm go off. Mirabelle eats lots and Jet eats lots and everyone is very happy and full and warm. I clear the table and put all the plates and cutlery in the 
sink. Eddie does the dishes. Mirabelle has a bath and Jet has a shower. Mirabelle pisses in the corner by the toys. Bonnie says she's not sure what it is about that corner, but Jet always pees there too. She says 'pees' I say 'pisses', but not before checking Jet isn't anywhere close.

We put the kids to bed. Bonnie reads Jet Ten Tired Teddies, Billy sings Mirabelle a song and people start arriving. Eddie ushers them into the lounge and I sit with them and we all keep quiet. Eddie goes to say good night to Jet and Bonnie walks into the lounge. Her eyes get wider and she says, 'Oh, hi everyone.' She has no idea what's going on, it's a surprise, but she's polite. Then Eddie comes back carrying a huge chocolate cake with candles and we all say, 'Happy Birthday.' People have brought other food and presents. After a couple of wines Bonnie says for her birthday she wants everyone to say what their super power would be. Someone says, 'Flying.' Someone says, 'I want to be able to get anything I want to come to me - like when I'm on the couch and the remote is on the table, I want to be able to get it without moving.' Someone says, 'Telekinesis.' Bonnie says, 'It sounds like you need a wife.' I laugh and no one else does because his girlfriend is there. Bonnie says, 'Sorry, oh, sorry.' There is silence and Billy asks, 'Bonnie why do you have two birthdays?' She says, 'I have two names, too.'

Eddie wants everyone to watch a video but everyone has work or school the next day. I stand by the heat pump for a while. Billy says, 'Have you done it yet?' I haven't. He tells me we're leaving tomorrow, while there's a break in the weather. I go to the kitchen. Bonnie is doing the dishes. There are three piles of white plates with chocolate on them. I say, 'Bonnie,' and she says yes without turning round from the sink. Does she remember the time the money went missing from her purse? When we were working late and everyone said it was me and I said it wasn't. She looks at me over her shoulder and wipes soapsuds around her hands. And I helped her look for the money, behind the couch and under the desks. I say, 'Bonnie it was me,' and here it is, and I hand her an envelope. I say, 'I wrote a note explaining it all.' I hand her the note and the envelope and they soak up the suds 
as she takes them from me. I say, I'm sorry and I'm clean now and thanks for having us. She holds the envelope and the note and looks at me. I look at the envelope and the $B$ from where I wrote Bonnie disappearing into the water. I say, 'It's all in the note,' and I'm sorry again and the money's in the envelope, I adjusted it for inflation. I'm trying to do better and sorry and happy birthday. 


\section{HANK NIGEL COOLIDGE}

THIS TIME IT'S A MIST. The woman in the fruit shop calls it 'Scotch mist' because it's 'too cheap to rain.' My grandmother said it was rude to call Scottish people Scotch and for girls to eat on the streets. She said it was unlady like to whistle. Once, I said to her 'What about giving head?' She pretended not to hear me and I walked away humming something.

I'm walking in the mist, in the morning. I have to walk into it to get wet and the wet sits on me like tiny bubbles so that every time I touch part of me I get wet all over again. I'm also sick. A draining, hacking sick; like there's the leg of an upright piano on my chest. I think I'm dying, but it's nothing serious. Someone's dying - somewhere, someone is really dying, but not me. On the way up the hill I see a huge earthworm. They come out in the rain. I measure it and it's as long as one of my feet and then up to where the stitching starts on the toe of my boot. It's as thick as my ring finger. It's huge and fat and phallic. I ask it what a nice girl like her is doing in a place like this - on the path in the mist, laying there. I ask if I can 
buy her a drink. She's coy. I put her in my pocket with some mud and grass, in case she gets hungry. I have to sort of fold her back on herself to make her fit, but I'm gentle, like I'm picking a scab. I call her Hank - Hank Nigel Coolidge. I tell her, 'We won't make a habit of this but today you can come to work with me.'

I work in a call-centre. I get to my desk, take off my jacket and hang it carefully on the back of my chair. It drips on the floor. Drip. Drip. Drip. I log into my computer, put on my headset and start answering stupid questions - politely. All morning I write, over and over, on my desk pad: 'Mrs Coolidge. Ms Coolidge. Mrs Hank Nigel Coolidge. Dr Coolidge.' I check her every now and then and say things like, 'What an idiot,' about the people who ring up. They get angry a lot. Our manager gives a prize every week for the best telephone face. The call-centre workers stand up sometimes and make claws with their hands and show their teeth at their phones - and talk politely. Our manager tells us people can tell whether we're smiling from the sound of our voices. People come to visit the callcentre, clients and our manager's managers, that's why we have to wear corporate casual and be careful when we're making obscene gestures at our phones. As my manager walks past, I ask, 'Are we having "Bring your daughter to work day" any day soon?' He says he doesn't think so and I say, 'Oh, okay, just checking.' There's no such thing as a dumb question.

Hank doesn't eat much at lunch - we go out. She's starting to dry out. I try to be livelier in my conversation. I talk about the weather and I talk about politics and then I tell her about a TV show I watched the other night about this guy and this other guy and how one of them got smallpox and the other one didn't. I swear I can see a tiny smile on her little wormy face and I feel better.

We get statistics at the end of each day: average time on call, average unavailable time and any complaints. After lunch my manager calls me into his office. My statistics are down where they should be up and up where they should be down. I say, 'A computer does these - it's all quantitative. You can't judge my performance on that.' My manager shows me a couple of complaints: a lady who 
said she couldn't understand me, and a man who said he didn't think I was concentrating. I say, 'People take the time to complain. No one takes the time to ring up and praise people. It's human nature.' He shows me the results from my last customer satisfaction survey. There are a lot of numbers and charts, but basically people are not satisfied. My manager explains that the call-centre rings these people up. I look through the charts and comments and say, 'This guy thinks I'm okay.' I hold out the paper to show my manager. 'Oh, yeah, there you go,' he says. I tell him I'm having personal problems - that I've started a new relationship and it has its challenges. He says, 'That's great,' and tells me to forget about all this, he just has to write down that he told me about my performance. Can I sign this thing to say he's told me? I sign the thing. Outside it's stopped raining, it's just grey.

Around afternoon tea time Hank and I start to have problems in our relationship. Hank says I don't excite her any more. I try to excite her. I make faces at the phone - she laughs a little and I wonder if it's enough. She says things like, 'Can we go now?' I try to explain that I need to dazzle them at work for the next little while because my stats are bad and there have been complaints. She says, 'We never go out anywhere any more.' I try to explain the pressures of working in a busy call-centre. She says, 'And, like, I'm not busy too?' I say I value her work and she says, 'You don't even understand my work.' All the time we're having this conversation I'm not taking calls. I've logged myself into 'Unavailable to take calls' status. I watch the seconds tick by on my computer screen. Finally I interrupt her, 'I can't talk about this now.' She says something about me being emotionally unavailable and I zip up my pocket.

On the way home Hank asks if we can have a little talk. My stomach drops. She says, 'It's not you, it's me,' and I start to cry and say, 'Don't do this - I'll do better, I'll be better.' She asks me to drop her off in the mud beside the path. As I walk away I turn and she's gone, burrowed away from me, and I say, 'I always thought that I'd see you, baby, one more time again.' 


\section{MAYBELLINE'S BABY}

\section{OTHER PEOPLE'S BABIES SLEPT. While Maybelline's baby,}

Earl, woke at 9:46 p.m, 10:53 p.m, 1 and 5; other people's babies were sleeping. Sometimes Earl would scream for an hour or so, sometimes he would go straight back to sleep. When Maybelline put her head on the pillow she had no idea how long it would be for. It had been ten months. Maybelline's friend had a baby that had been sleeping for eight hours straight, every night since it was born. Another friend's baby slept from seven until seven, every night since it was six weeks old. She collected stories like these. She heard some babies didn't sleep until they were one, two, five years-old - naughty babies. People with teenage children told Maybelline they were up all night waiting for them to come home. They laughed and said, 'It never gets better.'

She started saying stupid things, doing stupid things. People called it nappy-brain and laughed. She lost her sense of humour. Her reactions slowed. She couldn't believe it was legal for her to drive like this. She felt like it was doing 
permanent damage. She could feel herself becoming stupid. 'When all you have is your mind,' Maybelline said, 'that's scary.' She thought of her great-aunt with Alzheimer's - the first bit where she knew she was forgetting. Her great-aunt left a pot on the stove boiling. She looked at Maybelline confused and terrified through the smoke.

Maybelline joked about it being like being on drugs. She joked, 'If I'd known I could get by on this little sleep I would have partied more in my twenties.' She thought, I can't get by on this little sleep. Maybelline told her husband she couldn't do it any more - night after night after night. Each night she thought, tonight will be the night. The next time I look at the clock it will be 6:00 a.m. or 5:00 a.m. or 4:00 a.m. or anything that is at least six hours from now. It got worse. People said it would get better but it got worse. Every four hours turned into every three turned into two turned into one. One night she put her head down thinking, at least I'll get an hour. Earl woke up seveteen minutes later. She read books and listened to people. Her perspective went. She started to cry while she was walking along the street at four in the morning, pushing Earl, trying to get him to go to sleep.

Maybelline's husband left. He told her to fuck off and left. He came back twenty minutes later. She was hopeful he'd brought something back with him something that would help - some baby-sleeping machine. 'Nothing was open,' he said, 'it's two thirty in the morning.'

The next day, Maybelline left a pot on the stove boiling. Suddenly it all made sense - perfect sense. There was a God and that God had been watching the day Maybelline's mother got remarried and He was bringing down some kind of almighty punishment for the way Maybelline treated her great-aunt all those years ago. He was waking Earl up, pinching his toes and when that didn't work his ears. He was making Maybelline crazy like her great-aunt, so she could see how cruel she'd been. 
It was meant to be a treat. Maybelline's mother had asked Maybelline to sew something lovely for her great-aunt to wear to the wedding. Maybelline's father had died - become crippled for years, and died. Her mother was marrying the man she left to marry Maybelline's father. It was romantic. It was her mother's time. Maybelline was nineteen. She'd made her great-aunt a silk blend coat and a button-front dress. Maybelline's great-aunt was a stylish woman. She was elegant and nearly eighty at the time. The night before the wedding, Maybelline arrived home to find everything she owned on the front lawn outside her flat. Her boyfriend was throwing her out to make room for someone else. 'You'll be back!' she yelled and threw stones until he opened the window and said he was calling the police. She slept in a bus shelter that night. In the morning she washed and changed in a public toilet while the cleaners cleaned. She washed herself with pink soap from a soap dispenser and dried herself with hard paper towels. Then Maybelline went to work at the fashion store that employed her wearing her three hundred dollar dress and her eight hundred dollar boots and the same underwear as the day before.

The wedding was at twilight. There were candles in the small church and drinks before the ceremony. Her great-aunt arrived and there was a stain on the coat. God had turned up then, obviously. He'd been nowhere when Maybelline was evicted by her bastard boyfriend. Maybelline shouted at her great-aunt in front of everyone. She said, 'Well, that was a waste of fucking time,' and called her 'filthy' and 'messy' and told her she didn't deserve anything nice. People looked. Maybelline's great-aunt looked confused and terrified. Then someone said, 'Could you all please be seated.'

Later that evening, at the reception, when her great-aunt had gone home with a headache, Maybelline got locked in the toilet. The handle had come off in her hands. She clawed at the jam but she'd slammed it. She stood on the toilet and called out the window to her cousin who was having a smoke. He looked around and edged away from the voice. She was in the bathroom for an hour and all she 
thought about was how bad things were for her. She didn't think about her greataunt at all.

There was nothing Maybelline could do to make up for it now, except be woken every hour, on the hour, for as long as God saw fit, by something small and elegant. 


\section{CUCKOLDED}

JIMMY AND I ARE LYING IN BED, in the dark on the verge of sleep - he might already be asleep. I say, 'I read a story today about this guy, and his wife is late home.' He says, 'Mmm,' to show he's listening. I can't stand it when he isn't listening. Sometimes I say, 'Are you listening?' and he says, 'I'm listening,' and I say, 'You're not doing anything that would give me any clue you're listening. How am I supposed to know you're listening?'

Jimmy says, 'Mmm,' again and he could already be asleep and doing it in his sleep for all I know. I say, 'And he gets upset because she's not home and he starts to think she's having an affair. He starts to imagine his wife in the bed of another man - in the arms of another man, in his bed. So he calls his best friend for some support. His best friends answers and says, "It's late," and is short with him and tells him not be stupid, she'll be home soon. "Pull yourself together," that sort of thing,' Jimmy moves his shoulders like he's trying to get out of something, or into a small hole. 
'What the guy doesn't know, the first guy, is that his wife is in his best friend's bed. As he's talking to his friend on the phone, his wife is in the bed. The best friend is talking to him from the bed his wife is in - having her affair.'

Jimmy says, 'Mmm,' like he wants me to think he can't believe a best friend could do that to his best friend, to show he's listening.

'When he gets off the phone - the husband, not the best friend - he thinks for a minute and then he rings his best friend back and says, "Oh, you were right, she's home now, sorry for ringing so late."'

There's quiet for a minute. Dark quiet and some people go past outside our window, saying, 'Oh yeah, you did it,' and 'Oh, no I didn't,' and laughing. Then Jimmy says, 'That showed him.' Half his face is in the pillow so it sounds like someone is pulling his cheek back while he's speaking.

I say, 'What?'

Jimmy says, 'That showed the best friend.'

I say, 'What?' again and get up on an elbow to see if he's really listening.

'That showed the best friend that the guy knew he was sleeping with his best friend.'

'His wife,' I say.

'His wife,' says Jimmy.

'No it doesn't,' I say. Jimmy rubs his face in the pillow like he's burrowing like a star-nosed mole. 'It doesn't do anything of the sort,' I say, 'it's humiliating. The husband is humiliated and that's what's sad about it. Don't you think it's sad?'

Jimmy pulls the blanket over his shoulder like he's going somewhere. 'Mmm,' he says, 'It's sad, that man's wife was sleeping with his best friend and that man didn't know. That poor man.'

'Cuckolded,' I say.

'Mmm,' says Jimmy, 'Like a cuckoo.' 


\section{LIKE A GOOD IDEA}

IT WAS A SUNNY DAY. The receptionist gave Polly a form to fill out and said she would get a nurse. She came back carrying a Polaroid camera and said, 'Can you stand by that wall?' Polly stood by the wall and the receptionist took the photo. She shook the photo for a minute, said Polly could sit down and walked away. A nurse came and took the form off Polly and told her, 'Follow me.' They went into a small room with a high window. Polly could see the top branches of a magnolia in flower outside. The nurse looked at the form.

'It says here you've been thinking about killing yourself,' the nurse said, 'when did you last think about killing yourself?'

'An hour ago?' Polly said.

The nurse wrote something, 'It's not okay to think about killing yourself. Thinking about killing yourself is not okay. Understand?' Polly nodded. 'If you think about killing yourself while you're here you need to tell someone. Understand?' Polly nodded. 'Understand?' 
'Yeah,' Polly said. This all seemed like a very bad idea right now.

The nurse turned the form over, 'It says here you haven't had drink or drugs for a month. It's important that's the truth. If you go into detox you could die, so it's important that's the truth. Do you understand what the truth is?' Polly nodded. 'Is it the truth that you haven't had a drink or a drug for a month?' Polly shook her head. 'How long has it been since you had a drink or a drug?' Polly looked at her watch. 'I see,' said the nurse and wrote something down. 'We need to have a look in your suitcase now.'

Polly opened up the suitcase on the examination bed in the small room. The nurse took her perfume, her hairspray, her vitamin $C$ tablets, her paracetamol and the small amount of vodka she had hidden in a toner bottle. 'If you get a headache, tell a nurse,' she said. 'If you get a cold, tell a nurse. You won't need hairspray here.'

The nurse wrote some more on the form then took out a laminated sheet of paper with writing on it. 'These are the rules of this drug treatment facility. You need to read them.' Polly picked up the laminated sheet, looked at it and put it on the desk. The nurse finished writing, put her pen down and looked at Polly. 'Have you read the rules of this treatment facility?' Polly nodded. The nurse pointed at the sheet. 'If you drink you'll be discharged. If you take any drugs not given to you by a member of medical staff, you'll be discharged. If you form an emotional or physical bond with another patient which is deemed inappropriate by a member of therapeutic or medical staff you will be discharged. If you start a fight, start a fire, disobey - do you get the picture?' Polly nodded. 'There's no pressure to sign this form.' The nurse pushed another form towards Polly. 'By signing this form you're admitting yourself. You can turn around and leave right now. There are twenty other people who want your bed. I'm a tax payer and I don't want you wasting my money.' Polly signed the form, mainly to prove something to the nurse. 
'You can have cups not bottles. You're not allowed to have water bottles.' Lorna was Polly's buddy. They were going to be in the same therapy group. She was a middle-age woman, wearing track-pants and slippers. They both wore name tags, 'There's a lot to take in on your first day.' When they got back to the dormitory Lorna said, quietly, 'Do you think you'll be hanging out?'

'Oh, no,' Polly shook her head and stuck her hands in her pocket.

'It's just, if you are, you should probably tell a nurse.'

Polly nodded.

'You're in now. That stuff about being one month clean - they don't really mean it once you're in.'

A group of about ten women arrived in the dormitory shouting and laughing.

'You'll have your own room soon, anyway,' Lorna left.

The next morning Polly went to Occupational Therapy. The nurse told her she could paint a scarf or make a belt. Polly said she didn't care which and the nurse said she needed to start caring around about now, did she realise where she was? Polly said nothing and the nurse said, 'You're in a mental institution, an asylum, because of the choices you've made. I'm giving you a choice. Right now is where you need to start caring about the choices you make.' She had a silk scarf in one hand and a length of leather in the other. She was holding them up like they were two prize-catch fish. 'Do you want to make a belt or a scarf?'

'I really want to make a belt,' Polly said.

'So there's no one left who's talking to you that you can give a scarf to?'

'I could make a scarf for my grandmother.'

'That's the spirit,' the nurse handed her the scarf. 'Thinking of others is always the right choice.'

An hour later the nurse came over to the table Polly was working at. It was beside the window and the sun was streaming in. 
'Are those poppies?' she said to Polly. 'You can't draw poppies. I think I explained that.' Polly turned the flowers into balloons. They looked awful but the nurse said they were much better and she needed to get used to not being such a perfectionist. The scarf really did look awful - like a five-year-old did it. Her grandmother was dead so it didn't bother Polly.

She wasn't ready to tell anybody but when the judge had said she could have prison or treatment, treatment seemed like a good idea. It was testing her though. It was like prison but with cheesy shit thrown in, every moment of every day: psycho-therapy, meditation, interpretive dance. She'd been there three days and was already carrying round a stuffed blue bear. She'd been to grief-group and the facilitator, a large woman wearing peach, had said she needed to look after her inner-child, she seemed to hate her inner-child and she'd given Polly the bear. If she was seen without it or damaging it in any way by any of the staff she would be discharged and if she was discharged the sentence would stand and she would go to prison. As she sat in the big dining hall, eating lasagne with the bear on its own chair, she wondered if prison might have been the better option. She had to write her life story up until today and read it to her group tomorrow.

She'd come from a good home. She'd gone to a good school then she'd gone off the rails. She didn't know if she could stop because she'd never tried to stop. They sat in a room with no windows, in a circle, ten of them and the counsellor, Bill. She'd fleshed it out a little but it boiled down to that. Bill wasn't convinced. He asked if she was convinced. Polly said quickly, 'Yeah, sure, I can see it all now.' Bill said again that he wasn't convinced and asked if anyone else in group wasn't convinced. People started mumbling they weren't sure.

'You don't sound very remorseful,' one of them said finally.

If they'd wanted remorse she could have done remorse. She didn't want to lay it on too thick. The counsellor suggested Polly write a letter to her mother and 
ask how her using had affected her family. Polly said she wasn't allowed to contact her mother so that probably wouldn't work. The counsellor said he would contact Polly's mother and ask her to send a letter explaining how Polly's using had affected her family.

'I don't think that's really necessary,' Polly said.

No one talked for what seemed like a long time.

'Well,' said Bill, 'if you don't think it's necessary Polly, I think it's absolutely imperative that I do it today.' He turned to another new woman and asked her to read her life story.

'I was born into an alcoholic family,' she began, 'I never wanted to turn out like my parents.' She began to cry. 'I was molested when I was three years old and that's when I stopped feeling.'

'I would really prefer it if you didn't contact my mother.' Bill and everyone else in group turned toward Polly, the other new woman cried in quiet chokes.

'Polly,' said Bill, 'we're listening to Rebecca's story.'

'I know, and I'm sorry, but I would really prefer it if you didn't contact my mother.' Polly was folding and unfolding the piece of paper she'd written her life story on, 'Maybe I can rewrite it tonight and present it again tomorrow.'

'Where's your bear, Polly?'

Polly looked around the legs of her chair.

'Fuck,' she'd left the bear in her room. 'I mean - Flip!'

'Does anyone else find it interesting that Polly has lost her bear?' Bill asked the group. No one answered. 'What do you think it says to me about you that you've lost your bear, Polly?'

Polly shrugged, it was hopeless.

'Rebecca,' Bill said, 'what does it say to you about Polly that she loses her bear and then interrupts you at your most vulnerable?'

'Umm,' Rebecca grabbed a tissue from the box on the table in the middle of the circle, 'I don't think it shows much concern for me - or her.' 
'What do you think of that, Polly?'

If she left now she could be in Christchurch within a couple, maybe three, hours. If she was smart about it she would leave after group. It was free time. No one would miss her until dinner and that would give her a head-start. She could score by night-fall. The police were busy, too busy to worry about her for a couple of days. She could get a couple of days out of it, surely.

'And if you stay you could get a life time of freedom.' Polly looked at Bill. It was a lucky guess. She could take him. It was a lucky guess. He was small and weedy and stupid. There was no way he would fight back. There was probably something in his contract that said he couldn't fight back. He was a prick. Not even that lucky, she doubted there was anyone in the room who wasn't thinking about leaving. He liked to tell people what to do, that was clear, he liked to be right. He was a very small man. The smallest in the room, if she started it, there were at least five in the group who would join in.

'You really want another assault charge?' Bill said. Polly knew it was a trick like this whole stinking place. She shook her head.

'I'm sorry for interrupting, Rebecca,' Polly said and Rebecca carried on.

Polly sat on a balcony outside the nurse's station smoking a cigarette and watching a game of touch rugby. More than one staff member said, 'You could join in,' as they walked past her. Crying was the key. They were trying to break everyone and crying was the key. Bill would ring her mother, her mother would write a letter and when he read it out she needed to cry. Rebecca had cried. It was the opposite of anywhere else Polly had been. In some ways it was worse. They wanted you to do certain things and the easiest way through was to pretend to do those things. She'd done that for years. She'd just got off to a bad start because it was different here. She'd be fine now.

'You're shaking.' It was Bill. 
Polly threw her cigarette in a sand-filled ice cream container and folded her arms.

'Have you seen the nurse about that shaking?'

Polly nodded.

'Polly, do you have any idea about the truth?' It appeared that Bill was not off the clock. It was like a nightmare of compassion.

'I saw the nurse yesterday is what I meant.'

'Okay, were you shaking yesterday?'

'No, but I figured you were just talking in general, had I seen the nurse kind of thing. Sorry.'

'You can't con a con, Polly.'

'Is 28 Days like your favourite Sandra Bullock movie, or do you and your boyfriends sit around watching all of them?' She hadn't meant to say it. She hadn't meant to say it then, anyway. From Bill's immediate reaction she wasn't even sure she had said it. She'd been hoping to save it for later; the end, where she storms out and throws her chair and goes to prison and tells them all to fuck themselves and scores.

'I wish I could show you what it's like, Polly. Just for five minutes, I wish I could take my life and give it to you, just for five minutes. You have no idea what you're about to miss.' For a split second she wanted it. Then it was gone. 


\section{BLEEDING}

HOW LONG after realising I'm bleeding from my rectum should I wait before calling a doctor? This is the question that concerns me today. There have been others: What's it all about? Does she like me? Do I want fries with that? But today, as I shift paper and look busy, there is only one - and others dressed like it: Two weeks? Four days? Does cancer feel like this?

I'm a family man. I've been a family man three times, twice with the same family but I wish I'd at least tried it on with the woman in actuaries before my arse started hemorrhaging. One thing I know for sure, it'll be worse than I think. Around lunchtime while everyone else is at a Health and Safety meeting, I Google 'bleeding anus.' I get 'Rectal Bleeding,' ‘Colon Cancer Forum - Bleeding Anus??' 'Piles (hemorrhoids), 'Forum on Lipodystrophy,' and others in the same vein. What I' $\mathrm{m}$ able to establish before everyone comes back is the main causes of 'rectal bleeding' are Hemorrhoid, Fistula, Diverticulosis, Proctitis, Colitis, Polyps, Cancer, 
and Protrusion of the Rectum. Basically, I find out 'Rectal bleeding always means there is a problem.' I decide it's cancer. Cancer would be a problem.

I think about money and fame. I think about my funeral and sex - sex with more than one woman, sex outside, in cars, on building sites. I think about food, about how I haven't had a shit since I started bleeding. I think about losing my hair - losing more of my hair. I don't have a pair of pyjamas and my wife may be the last woman I ever sleep with. I think about how annoying my kids will be when I come home from the hospital to die.

I ignore the report I'm supposed to finish and the Conditions of Internet Use form I signed. I Google 'Cancer,' and find out that 'The American Cancer Society is dedicated to eliminating cancer as a major health problem by preventing cancer,' and wish I'd eaten better. I Google 'Death,' and discover 'According to near-death accounts, the reason for our very existence is to attain spiritual growth,' and wonder if you can fool God. I Google 'hot young women,' and find out Google has an image display option. I think about working late. All the while, every twenty minutes or so, I go to the third stall from the door in the seventh floor men's room and find my rectal bleeding has not stopped. Five days? Three weeks? Hours?

About 4:35 p.m. I think about drinks, how long I can stay away from home if I go out for drinks. I send out an email. My boss replies all 'It's Tuesday' and then sends 'How's your report coming?' His PA replies she has book club. The smart arse who wants my job replies all 'It is indeed Tuesday.' I think about drinking alone well me and my rectal bleeding - and decide that it's not really drinking alone if you're dying, and I am dying.

Dying for a drink I laugh. I impress myself. 'He kept his sense of humour right until the end.' I call my wife. The kids are screaming. I tell her I'm going for drinks. She starts screaming. Just before I log off I get an email from dorothy.kinbote@actuaries and this day is going to end better than it started. She replies 'Tuesday's a good day for a drink' but she can only pop out for a quick one, she'll be up in a minute. I think about rectal bleeding as a sexual stimulant. I've 
read about that sort of thing. I've read about that sort of thing this afternoon Boolean searching. She exits the elevator smelling of make-up and says she can only pop out for a quick one because she has to get home because it's Tuesday. Her hair's different from the way it is at work and she says it's a shame no one else can come. When I stand back to let her into the elevator she says, 'You go first,' and then she goes first.

Like I say, I'm a family man, a family man with a bleeding arse - which at present I am choosing to call 'rectal bleeding'. You don't get to be a family man without knowing how to become a family man. One thing family men know is how to find a family woman. The woman from actuaries is not a family woman. She's no strings, no games, just a couple of rounds of 'What's a nice girl like you doing in a place like this?' She's getting prettier with every drink. She's coy and touches my lapel. I touch nothing, I'm a family man.

I'm thinking, how many visits to the men's room do I have before it starts looking fishy? Imagine if the shit that wants my job could see me now. I wonder if I should take a photo of me with her to my next performance review. I think better of this almost immediately. Does she want another?

She's looking at her watch. Looking at her watch is not her looking at her watch. Looking at her watch is her not looking easy. I tell myself I need to shift slowly from unavailable to available, otherwise it's all over. It's like catching a fish. What I imagine catching a fish is like, I've never been fishing. She would probably prefer the shit that wants my job; he's what I would call very unavailable. I need to shift slowly so that she doesn't see just how available I am. She doesn't stand a show with him, he's unavailable - like for real.

So it's me - buying her drinks and pulling my jacket down when she's not looking, sitting on the edge of the stool making sure not to sit on my jacket. If things get really bad it's my only line of defence. She's drinking vodka lime. I'm ordering her doubles. There's a limit to how long this can go on. How long I can 
go on. There's always a limit. Even when you're eighteen and ready for anything there's a limit. She knows that, I know that, the bartender pouring the drinks knows that. It's like an invisible line. You always know which side you're on but you never quite know how you got on that side. I look at my watch: five visits in an hour? Ten visits in an hour? Then it dawns on me - I need to phone home to say goodnight to my kids. Available can masquerade as very unavailable for split seconds. When I get back from the phone call I tell her her hair looks nice. I tell her I like long hair. She says people say she's too old to have long hair. I tell her her hair looks nice. She says her hair needs to be cut badly. I tell her she wouldn't want it cut badly, surely? It goes over her head. I tell her her hair looks nice.

She's boring me spineless. I'm looking at my watch. I've been on the wrong side of the invisible line for about three-quarters of an hour. I've been to the men's room eight times in thirty-five minutes - mainly because I have to, but partly because I want it to look fishy. She has no jokes, bad breath and huge tits. There's only one thing to do and that's keep drinking and hold on for dear life - the bitter end. I'm looking at my watch and beginning to get tactless and my words slur and her bra strap slips off her shoulder. It seems like only a matter of time but I thought that an hour ago. And my arse is still bleeding. As she smiles and smokes I wonder how much blood I've lost. Equations go through my mind as she hoists up her bra strap - again. I'm making fluid containers in my head and trying to remember cosine and tangent and filling them with blue liquid and measuring them out into cubic centimetres, metres, kilometres - surely not kilometres? She's laughing and smoking. The pub is loud now and I'm nodding and shaking with her. Surely, it's just a matter of time - just a matter of time. Time, time - look at the time - will she have another?

Go on.Go on. And she does. I get another, wishing the whole time I had called the doctor during business hours - surgery hours. Wondering how late A \& $\mathrm{E}$ is open. Wondering if I could say it was an accident, thinking about ACC and all 
the time smiling back at her. Frowning when she frowns, nodding when she nods. Mercy can she talk: self help books she's read since her husband left, movies she's seen. 'Do I like Vin Diesel?' I'm hanging on and hanging on. I decide it's only a matter of time. Either she'll suggest it or I'll die of blood loss. Can the rest of your organs bleed out your arse? Like, could my heart bleed out my arse? My brain? My feet? Can you lose blood up hill? If she's talking about movies are we closer or further away than we were when she was talking about her ex-husband? If we're closer, are we close enough for me to suggest it?

Did I want to go dancing? Um, no. Not if she was the last woman alive and there was some crazy fire thing going on and you had to dance to get out of it. No, I do not want to go dancing. I smile when she smiles. Fuck.

She's stopped pulling her bra strap up. Surely, sweet Jesus, it's just a matter of time. I nod when she nods. I wish I was bleeding out my face. She comes closer, to tell me a secret. I can see the holes she used to put earrings in. Then she pulls away to laugh. I can wait five more minutes, I decide for the ninth time in two hours. The bar gets noisier and noisier. 'Hospo night,' I say. I mean to think it but I say it. She doesn't hear me - she keeps talking. She loves dancing. She flicks her hair and plays with the straw in her drink. So I wait for the next time she smiles and nods and I smile and nod and say, 'Fuck you.' And she keeps talking. 'Fuck me,' I says and, 'Shut the fuck up and suck my dick.' She keeps talking and I wish she was bleeding out her face. I wish every fucker in this bar and all the fuckers at my work and all the mother-fuckers that cut me off on the motorway, and my wife, and my wife's mother, and that shit that wants my job and my boss, and whatever the fuck disease I've got, and Jesus, I wish they'd all bleed every inside they have out of their faces. Where can you go dancing on a Tuesday night? Does she mean dirty dancing? She smiles when I smile. Her bra strap's down, no sign of going up again. She smiles when I say dirty dancing again. Of course I'll have another. Does she know that fucking shit? He wants my job. I know. I know. He is - little fucker. 
She knows. I tell her she's a very sexy lady. She pushes my shoulder and says oh, or no, and wags her finger at me because I'm naughty. I say it's true, she's a very sexy lady. She says she's no lady.

I have a new question. As I help her along the street, the two of us getting so close I can smell her hairspray. She smiles when I smile. She nods when I nod. I have one question: When you already have rectal bleeding, how long should you wait after discovering you're pissing blood as well before you call a doctor? I laugh. She's getting more beautiful with every step. She's licking lipstick from her teeth and my car has dark upholstery.

She stops and bends into a doorway to vomit. I walk on, into the light of a street-light. She says, 'Jesus. Are you bleeding?' I wipe the back pockets of my trousers like I'm looking for my wallet.

'Jesus,' she comes over, 'You are. Look at you - you're bleeding like a stuck pig.'

I say, 'You're the pig.'

'You need a doctor,' she says wiping her mouth. She smells of vomit. 


\section{SHOPPING}

\section{MAY'S MOTHER, JANE, WALKED TOWARD}

THE CAR, lighting a cigarette in the wind. It looked like she was holding something in front of her face with both hands; something small and soft, like a kitten. May had never seen her mother holding a kitten. They'd had a cat. It had been their neighbours', they'd fed it in the holidays and the neighbours said to May, 'It likes you so much. You should keep it.' He was a large ginger cat called Tiger. May would call him and hit the cat food tin with a spoon. She was sure her mother had killed Tiger. Jane denied it but May remembered coming home in her green and white school uniform and brown roman sandals to find Tiger gone. It was always summer in May's memory. So hot she didn't need to wear a cardigan; always in roman sandals or bare feet. Her mother said she didn't know where Tiger was and sometimes cats just crawled away to die. 
There was a lot of cat food left. May's cousin offered May's brother five bucks to eat Tiger's food. Not all of it. They agreed a tablespoon of cat food for five dollars and shook on it. Her brother ate it but it turned out their cousin didn't have five bucks. At a family meal, when they were teenagers and someone was telling the story, her brother said, 'Yeah, what about my five bucks?' Their cousin shrugged and everyone at the large family table laughed except May, who said, 'What about Tiger?' The laughing stopped, not because everyone knew what had happened to Tiger but because they knew Tiger always started a fight between May and her mother. Almost everything May said started a fight with her mother; she was always trying to start fights. May's father laughed to himself and said, “"What about my five bucks?"' Everyone laughed again, only not so loudly. At the hospital, during family counselling, May's mother said, 'You never even had a pair of roman sandals. I hate roman sandals.' She said it was all in May's head - all of it.

May wanted to say, 'You can't smoke that in here,' but she got into the car and waited and pretended to read the shopping list over while Jane finished the cigarette. May and her mother were going shopping for food for Finnegan's first birthday party. Jane had given Finn a card saying, 'Happy Birthday Darling, You are so lucky to have such fantastic parents.' She meant May and her husband. Jane bent down and stubbed the cigarette out in the gutter. She got in the car and said, 'This is nice,' and squeezed May's knee. May smiled and started the car. It was the first time they were spending time alone together in years.

Every time a car came close Jane inhaled swiftly, realised, and tried to cover it up. They were driving May's father's car. He held the keys out to May, then thought better of it, turned and gave them to Jane. As they walked down the path, Jane put the car keys in May's palm and said, 'You drive, eh? You know the way.'

'Nice day,' May said as they came to a stop at some traffic lights.

'Yeah,' her mother looked out the window. 'Let's hope it holds up for the party tomorrow.'

May nodded. 
'How many kids are coming?' Jane said.

'I'm not sure.'

'Oh well, I'm sure if we get enough food for twenty that should do it.' Her mother put both hands between her legs and pulled her shoulders up to her ears. 'Shouldn't it?'

The supermarket car-park was busy and the sun was glinting off all the cars.

'Should have come earlier,' Jane said.

May parked the car.

In the fruit section Jane said, 'Strawberries.'

May took the shopping list out of the back pocket of her jeans and said, 'I have a list.'

Her mother stood beside the trolley holding the strawberries. 'Does the list have strawberries on it?' she said.

May looked at her then looked at her list and they both laughed.

'Strawberries do not appear to be on the list,' May said.

'I can change that.' She opened her bag, looking for a pen.

They both laughed again.

'We can't really afford them,' May said.

'I can afford them. This shop's my shout.'

'That's kind but we have money for the shopping.' When she had wanted to put it right, May added up all the money she owed her parents and it came to eight thousand dollars. She made an appointment to see her father. People told her he would probably say, 'Don't be silly. It's just great you're doing so well.' When May showed him the figure, itemised into money stolen, fines and bills paid, her father said, 'That should just about do it.' He gave her a bank account number and said if she could organise a direct debit, that would be great. May got a job in a fast food restaurant and when it was all paid back she was invited to Christmas dinner. Her father and mother handed May an envelope and in it was a cheque for eight 
thousand dollars. May and her father did the dishes and while Jane was in the back yard having a cigarette, he said, 'Don't fuck up,' and he meant it.

'We can go halves,' May said. She wanted her mother to tell her she was doing a good job of looking after her family but more than that she wanted to get the shopping done, and she didn't want to fight.

Jane put the strawberries in the corner of the trolley, 'All right,' she said, 'but I'll pay for the strawberries.'

They began to get the things on May's list: oranges, bananas, apples. May read from the list and Jane went to the shelves and picked the best fruit and put them in the trolley, carefully, keeping the strawberries in the corner away from everything else, like they'd been naughty.

'Do you have to weigh them?' her mother said as May put the bags of fruit on the scales. 'I don't shop at this one.' Jane looked around nervously at everyone shopping.

'What about chippies?' Jane took a packet off the shelf.

May looked at her list, they both laughed.

'Well, I want some chippies,' Jane said and grabbed a couple more packets. 'And some dip.' She put the chips next to the strawberries, 'Don't let me forget dip.'

In the baking goods aisle, while she was looking for lemon essence, May realised she'd lost her mother. Jane had gone to get some olives - they were on the list but they'd missed them at the deli. She'd been away too long for just olives. May looked around, holding the small bottle of yellow liquid. She put the lemon essence in the trolley then went to the end of the aisle; her mother was looking at basmati rice. 'It's really cheap here,' she said. 'I might start coming to this one.' Her mother was carrying a small plastic container of olives and a white plastic bag. 'This is cheap, do you need rice?' May shook her head. Her mother put the rice back on the shelf and put the olives in the trolley. She held the plastic bag close to her and whispered, 'Some ham - for your dad's lunch.' 
'I was going to make lunch,' said May.

'I know,' Jane jumped a little bit without leaving the ground, 'it's just extra. I can put it back.'

'Don't put it back.'

'I'll put it back, eh?'

'Nah, put it in the trolley.'

'But you've made lunch.'

'I haven't made lunch. I was going to make lunch. We'll have sandwiches.'

'I'll put it back,' Jane walked away.

May watched her talking to the man behind the deli counter. She handed the plastic bag over. The man shook his head and frowned. Jane smiled and waved and as she turned toward May laughed and said, 'No problem.'

May looked at her list as they joined the check-out queue.

'Dip!' her mother said, raising her hand. 'I wanted some dip.' She darted off toward the fridges. May looked at her watch. They'd been gone nearly an hour. May had used the eight thousand dollars to finish her degree. Her father hired a suit to wear to her graduation. Jane had stood in front of her, fiddling with the collar of her shirt, trying to get it to sit under the gown, then over it. Her mother looked down through the bottom of her glasses, concentrating only on the collar. Finally, she patted it and said, 'That'll do. That looks okay.' Jane tried to look down at the collar, then touched it, 'Thanks,' she said. 


\section{A VILLAGE}

ONE YEAR WE GET MICE. There is shit and mice everywhere. I have to sort it out while you go to war to make peace. Years later, I see you and you're holding a blue beret. The mice are everywhere. They pop out when I open doors, move curtains and lift things up. They get in my hair when I sleep. Their tiny, sharp claws get caught in my clothes. While I shower, five or six of them scurry around the rim of the bath, covering their eyes. I sing to them. They have breakfast with me, them, their children and, as the peace draws on, their children's children. They shred the telephone book for a bed and we talk for hours. I talk for hours to mice.

I tell them that M's ute has been parked in D's driveway all night and that D is away and D's missus is home by herself. Our next door neighbour works at the Tegal factory. She shouts a lot. I shout a lot. We don't talk to each other. Her husband is away, too. Most of the men in our street are away. M is a pogue so he's not away. I wonder how $\mathrm{T}$ will feel about his wife being fucked by a pogue. 
The mice stop coming around after your friend visits, saying you asked him to do something while you were away. Your friend parks his ute in your driveway for a while and crawls around under your house. He stays for a coffee. While we're sitting in the kitchen having coffee he looks out the window and says, 'Is that M's ute?' I shrug my shoulders and say, 'I wonder what that's doing there?'

After your friend visits, a bad smell comes from one of the walls. You tell me, what do I want you to do about it from over there, and to call your friend. I call him. He parks his ute in your driveway again and moves the fridge and there's a dead mouse and he picks it up and takes it somewhere. I figure they'll come back now. You come back. I make dinner and you go out and come home and don't say anything and also say you're angry I couldn't sort out the mouse thing by myself and I'd live in squalour if I could. I do the vacuuming. The phone rings a lot and it is often women asking for you. Some of the women I know and most of the women I don't know. You tell me I'm crazy a lot. I throw things at you. When you go out I just throw things. You cry sometimes. I hide your car keys behind the fridge. I say it serves you right, you shouldn't have done the things that make you cry, and you cry some more. You hit me. I hit you. You almost strangle me one night under a full moon. One of your lungs deflates. It wasn't me - and you still run the Buller half-marathon. People feel sorry, mostly for me. I feel sorry for me. You go away again and tell me to be gone by the time you get back. You're away for a week. During that week you and your co-workers see a deadly sea snake. You hold it up with a stick for a photograph. After you tell me I feel sick with excitement every time I think about it. I buy a pair of dark sunglasses. You drive badly. You take up smoking. You go for long swims. You can't swim.

Later, years later, the phone rings at 5:30 a.m. It rings again at 5:45, then again at 6:02, 6:09 and 6:12. I don't want to answer the phone. Most companies that run competitions that give away a lot of money don't open until 9:00 a.m. There are messages - your best friend, then my best friend. At seven fifteen I pick up the phone, it's your best friend. I say 'Oh,' and 'Oh, well, thanks for calling.' I go to 
work. I start to shake while I'm typing. The phone rings. It's your best friend and the army. I say 'I'm not sure what this has to do with me any more.' And they say I need to be down there as soon as possible and they can organise an army flight for after lunch. I say I wasn't planning on coming down and they say I need to come down. I don't think I need to come down. My boss says I need to go home and I say I need to finish the report and she says I have to go home and come back when I'm ready. I say I'm ready now. My best friend meets me at the airport. You slept with her. You had sex with her in the back of a car, or maybe at her house - I lose count. We drive to her mother's house. I have one bag. We have a cup of tea. I don't want to go to your house. We go to your house.

There are lots of people at your house most of whom I never wanted to see again - all of whom I never wanted to see again. It's a nice house, your house; I could imagine you being happy there. It has a nice backyard you could run around in and a fence. You still have the toaster I melted a bread bag to. You were angry when it happened but you still have it - and the coffee cup with the black cat sitting on a patchwork quilt. Some idiot takes me to your body and I cry because there are lots of people waiting for me to cry. People are angry at me, then and later, years later, people are angry at me and I am angry at people.

I'm introduced to woman after woman that you slept with in cars, at the barracks, in toilets, at your house, at their houses. My father said to me once, 'Oh, that's right, you've never lived in a small town.' You're like a village.

I'm holding a hot cup of tea with no milk, leaning on your bench. One of the women tells me, 'We all thought we were special to him but he loved us all the same. We were all special to him.' I throw hot tea in her face, smash the cup and cut out her eyes - in my dreams. Someone else tells me you were always faithful; whoever you were with at the time, you were totally with them. I never thought I was special, that's what makes me special. I leave. At the top of your driveway there's a cat-fight going on. I'm introduced to your new girlfriend who isn't being allowed in by one of your other girlfriends. It's an odd movement, like a two- 
handed backhand, but it breaks her jaw and maybe her nose. I spit on her while she's crying and bleeding into her hands. People look. I leave for real. The police are called. They tell me it's not okay to hit people. I don't go to the funeral. I lie to my best friend. I tell her when I get home I'll organise a small memorial service for you. I don't. I'm pretty sure I had no intention of doing it. 


\section{SOMEONE RAISES HIS EYES}

\section{SOMEONE ELSE GETS SICK AND MOST LIKELY}

DIES. Anyone left is dishonest in a humiliating and degrading way. No one feels anything. Anyone who should feel something looks at the sky instead. Usually it's dark. There's a lot of talk about weight and sound and not much to see - except the dark sky, which is always empty. Everything that happens was probably always going to happen. I'm boring myself. I try to be clever and am stupid. I try to be earnest and am funny. When I'm not funny it's like rooms full of people don't laugh. That's how quiet it is when I try to be funny and am not. I try to change things. Poke them with sharp sticks - try to get a rise. No one feels anything. I repeat myself and don't realise it until someone points it out right after they say it's funny.

Right in the middle of someone not feeling anything and nothing happening it starts to sound familiar. I Google it and I'm quoting The Twilight Zone. There is 
usually irony and cynicism, but not this much. Quoting The Twilight Zone is not a joke. Quoting The Twilight Zone makes me the joke. I studied Latin. I swing from thinking I'm a joke to thinking writing is harder for geniuses ... geniui? I studied Latin because Pound did. I did Latin so I could become a fascist. Someone told me once, Pound was a fascist. They leaned over me, drunk, and I was drunk too, and said 'Pound was a fascist!' It sounded clever and whenever anyone said 'Pound' or 'Eliot' or 'Petals on a wet, black bough' I would yell out 'Pound was a fascist!' like Tourette's - to look clever. I said I liked his poetry. I didn't know his poetry. I called him 'Pond' twice, in a tutorial run by Riemke Ensing. She's a poet. I am not. I told her I hated Katherine Mansfield. I didn't actually tell her that - I told everyone else that and said I was going to tell her - if I got the chance. I said I never got the chance. I got the chance - I just never said it. Years later, when I'm sober, I tell Heather Murray. Not so much that I hate Katherine Mansfield but enough for her to put in a formal complaint. The lecturer running the paper tells me I have some good ideas but won't ever amount to much. It's like a curse. From then on they all have ideas, nothing happens and they all have ideas instead of feelings. This one doesn't have a memory, this one's only read one book, this one watches too much television and they all look at heavy, empty skies, like retards. The lack of compassion makes it all hard to read. That's what someone else says. I think about screwing it up. But it's a computer file. I think about deleting it, but it might be worth something one day. I think of Emily Dickenson. Dickensen?

It becomes therapeutic, the lack of compassion, the absence of emotion, of anything happening. It's as transparent as me trying to work it all out on paper. I get embarrassed. Pissing-myself-in-a-crowded-room embarrassed. And frightened - of everyone I've ever met and what they can see. I have no idea how to change the settings on my computer and have to type 'Tuesday' every time I want an mdash. Painting would be easier - baking. Everyone's a critic. I decide to do some research. 
I read so much about cancer, I think I have cancer. I ask my doctor something other than 'What does cancer feel like?' She tells me the mark on my arm doesn't look like melanoma and I don't scream, 'What about my lungs?' 'My liver?' I see a friend on a Monday night, a writer - a real writer. He's just finished the book a publishing company asked him to write. The publishing company asked him to write a book and he wrote it. One of our other friends, another real writer, says there's no market for short stories, I should write a novel. The first writer says, 'Except in the States - write for the States.' Our other friend makes a tsk-ing noise, raises his eyes and says, 'Stop pissing around and write a novel.' By Friday one of them is in hospital with something exploded, blown up by a tumour and I think about writing about it. That's the type of friend I am - the imaginary type. I think about how one day when we're all famous writers someone who likes what we wrote will talk about the conversation we had four days before one of our stomachs exploded under the weight of a tumour that had spread to one of our livers. I read Illness as Metaphor and decide positive thought is useless when you're dealing with cancer. The friend, the tumour in his liver, it disappears. And someone else looks at another heavy, empty sky and thinks about someone dead probably violently.

On a Saturday a couple of weeks after the liver tumour disappears I start bottom trawling my life for something, anything interesting. I overhear two twelve year old girls talking about having to block someone from their profile. One says 'Did you pay for the damages,' and as I'm trying to copy it down that's all I can hear - they're talking too quietly. I think about all the times I've let people down, then have lunch. I sit in the only sun I can find and there's a cat. I hate cats. I think about writing about someone who hates cats so much and I think about the rodents at my house and the headless, furry, four-legged things that chased me around for years. Out from under cars, out from under couches and the shaking and I think I will never write about that - and I do because I'm full of shit. I think maybe I need to let some air in. I go for a walk and, everywhere I go, everyone is 
talking too quietly. I check my email. I feel physically ill with what a loser I am. I dream about being cool - like Katherine Mansfield - and about talking quietly, or not at all. I think about what I would most like to eat. If absolutely nothing stood in my way; not pride, not the law, not plain human decency. I can't think of anything because I have no imagination. I look at the sky. It's blue and wide and goes on forever - pregnant with possibility. Ah Wellington, you placey, placey place.

I think about how much time I'm wasting while everyone I care about is working their arse off so I can waste time. I write fan mail because I can't stand to write another sentence - like a twelve year-old girl. My mother asks how it's going every time we talk and I feel ashamed and tell her good, and how's the garden? She tells me about someone who made a million dollars. I say, Lloyd Jones, and she says, 'Keep at it - a million bucks.' My dad tries to read The Da Vinci Code when it's on special at the Warehouse but gives up because there are too many characters and too much going on. I think maybe someone could care about cats. I go back and change 'hate' to 'love' in a Replace All and now it's awful - more awful. I kill the cat - a number of ways. I name the cat Spotting after my favourite Raymond Carver story, sure it's either clever or something else. When someone talks about someone else being sad the cat is gone someone raises their eyes. I check and in every one someone raises their eyes to the ceiling or lifts their eyebrows - it's the only show of feeling or hint they're in the same room as anyone else - a look at the ceiling - no doubt a dark ceiling, with no God. 


\section{DAISY}

\section{DAISY LIKED TO PUSH THE TROLLEY. She would}

push it forever if she could - to the coast. But her mother or father would always pick her up and turn her back on her path. She would keep pushing and walking her little side-to-side steps, thinking she would push forever in the new direction, but soon she saw the gate and home. Her mother or father would open the gate and she would turn the trolley in a banging, scraping arc, up the path to the steps that led to the door. Her mother or father would lift her into the house, Daisy still holding the trolley, and she would push it some more, up and down the hall, into the bathroom and behind the curtains that hung to the ground.

The trolley had been built by someone else's grandfather in a workshop lit by a single bulb. He'd purchased the wood from a small store he could walk to but he'd had to catch a bus for the wheels. Yellow plastic wheels that rattled, and wobbled slightly. When he found them he held them up and said, 'These are them.' On the bus home he took them from the bag and held them again and 
thought, 'They're as close to perfect as you get.' The nails that held them on were rusting now from puddles and rain. The tray lay low to the ground and the handle came out at a forty-five degree angle. Daisy's mother bought it from a shop full of old things, along with a bucket and a wooden chair but Daisy had found it. Tucked away between an old bath and a rusty bike, she pulled and pulled and the trolley popped out. She'd fallen to sitting, that hard fall that stops so abruptly and clamps your teeth together but she wasn't down for long. There was dirt in the corners of the tray, crushed as fine as sand. Daisy pinched at the grains with her tiny fingers, then wiped at them swiftly with a flat hand but they never went away. She pushed the trolley a little from her sitting position and it rolled away, so she got up quickly and began pushing it, both hands on the handle, laughing in a, 'huh-huh,' way. Daisy thought it had been left there for her. She didn't know about giving things up or getting taller. She was small, not two years old, and everything was there for her.

At first, in the confines of their small house, Daisy got the trolley stuck constantly. She would push it forward a few steps and its corner would catch on a chair leg or the edge of something bigger. She would push and push harder and sometimes the back wheels would leave the ground and Daisy, still holding the handle, would fall face first, then knees out to save her face and she would cry cry out. Her mother would wipe her hands on a tea-towel, saying, 'It's okay,' and as she lifted Daisy and put the trolley on a clearer path, 'sometimes these things happen when you're pushing a trolley, but it's okay, it's all part of pushing a trolley.' Daisy's mother, Alice, was always busy.

One Monday, Daisy turned the trolley for the first time. It got stuck and she pushed and pushed and then pulled and it came free. She shook it then pushed it again and all the sticky places disappeared.

Daisy sometimes stopped pushing to watch her mother being busy. Eventually, as the busy-ness went on, she would raise her arms and call out. Alice would hand her down a piece of pumpkin, slimy at one end and tough at the other. 
Daisy would play with the pumpkin for a moment; pushing her finger as far into the slimy end as possible, then she would look at her mother and go to the wooden chair her mother had put beside a Formica table. Daisy would drop pumpkin on the rented carpet, leaving another orange thumbprint, and hit the seat of the chair with both hands, saying, 'Ah, ah.' Alice would try not to look up. If she could just finish cutting the pumpkin for the soup for her friend who had twins who both wanted feeding at the same time but could only be fed one at a time. Then she would play with Daisy. Alice tried not to look up and chopped the pumpkin on the board with the seeds caught in a slimy, orange net. 'Ah, ah.' Alice chipped at the green skin like a sculptor working limestone. 'Ah - ah!' Alice looked up.

Alice would fill the sink with bubbles and plastic cups and Daisy would eat the bubbles and spill the water, but she wanted the knife. Alice would chop on the glass chopping board and it would make high-pitched bangs like something was about to break. Of everything on the bench that she could have and everything on the bench she couldn't have, it was the knife Daisy wanted most. Alice dreamt when she was awake and in one dream she would, in some strange mind, hand Daisy the large chopping knife, put her on the floor to play, and turn back to her cooking. Daisy would run away up the hall and trip on the threshold to her room. The knife, at an impossible angle, would puncture her cheek and her skull and somehow her heart, and she would not call out. Her mother would sauté the onions and garlic, add nutmeg and stir the pumpkin into the sizzle at the bottom of the big pot. She would think, it's calm and peaceful - the way it used to be, and add the stock. When it came to a boil and she'd put the pumpkin skin, green and chipped off, in the bin and cleared the bench, she would see the knife was missing and think, where is Daisy? Alice would see the trolley in the lounge and think, that's odd, and look up the hall and see the fallen girl. She wouldn't see the pool of blood until she was standing over her. She made it all in her head; her stomach was a knot of fear as she did. So Alice stopped chopping, filled the sink, pulled the 
wooden chair to the bench and stood Daisy up on it, putting the chopping knife well out of reach.

Later, after they took the pumpkin soup to the friend, and Daisy had seen the twins and tried to roll her trolley over them both, one at a time, she found the pumpkin under the Formica table and put it in her trolley with the two potatoes, the plastic bottle full of rattley chickpeas and the plastic keys she took to her bath each night - in the morning too, if she got porridge in her hair. She could hear the gate from anywhere in the house. When the metal bolt slid it squeaked, and Alice would shout, 'Who's that?' with equal excitement every night. 'Daisy? Who's that?' Sometimes Alice would cover her mouth with both hands, like she was praying, and open her eyes as wide as they would go. Daisy would run to the front door, she would reach for the key inside and try and Alice would call from the kitchen, 'Don't stand too close, Puss. Stand back.' The door would open and it would be her father, Lucas. He lifted her up so she could play with the headphones that hung on cords from the collar of his jacket. He would kiss her and kiss her and kiss her again. His cheeks would be cold. Daisy would smile but not look up, as if the smile, like everything else, was there just for her. Lucas would take her to the bedroom and put her on the bed and she would crawl over and reach for the remote and turn on the television and laugh, 'Huhuh.' Lucas would change out of his suit and shout, 'How was your day?' Alice shouted back, 'We had fun, we visited the twins and Daisy pushed her trolley, we had a good day.' Then Alice would come into the bedroom, wiping her hands on a tea towel, and Lucas would kiss her and say, 'Nice to see you.' Alice would say, 'What are you watching, Puss?' and Daisy would look up and smile so wide her nose would scrunch and her eyes would squint. Lucas would look at her and giggle. He was glad it was over. Sometimes it felt like Daisy had been up all night, every night, for the first year. It felt like no one had slept and all three of them had gone a special kind of crazy. Crazy like they were too tired to be sane. He'd broken a couple of his fingers when she was 
three months old. He was in hurry and he'd slipped on grass growing through paving stones. Grass wet at lunchtime because it was August and there was no sun to dry it. He stood up and his hand ached and his arm ached and he felt dizzy and sick with the pain. An ambulance was called. He'd pleaded with them not to call an ambulance but an ambulance had been called. His little finger was dislocated and the two next to it were broken. They gave him nitrous and said, 'Are you ready?' He said, 'Is it going to hurt?' and they said, 'He's not ready.' At the same time one of them dropped a book. Lucas jumped as the book hit the floor and the doctor cracked it back and Lucas jumped again at the pain of his smallest finger being snapped back into its socket. He'd called Alice when he could. They were going on a plane that night. Not a long trip, it was for Alice's birthday, to visit her parents. He'd been getting her a present when he fell; he was late for a meeting. He thought he could make it to the shop and back but he was late for the meeting and he ran and he fell and he'd broken two fingers and dislocated one and could she come and pick him up from A \& E? They decided to go anyway - Alice's parents could help. Daisy cried the whole way up on the plane and someone complained. Alice got angry at the complaining person and at Lucas, who was in too much pain to get angry and should have brought her present earlier and not been running. Lucas sat in the seat in the plane, wishing with everything he could muster over the pain and the exhaustion that he could go back and not run and not fall and not let Alice down on her birthday. He was glad it was over and Daisy was smiling her scrunchy-faced smile. Alice tried to do one too and Daisy laughed and soon all three of them were scrunching their noses up and squinting their eyes and smiling as hard as they could.

On Saturday mornings it was all three of them for a while after breakfast. Daisy would eat her porridge and her toast and put her banana beside her on her high chair. If no one was looking she would put porridge in her hair and in her ears and in her eyelashes and brows. She had a bath. If she was quick she could get the 
banana back before her chair was tidied away and walk around in just her nappies, eating banana and squashing it in her hands. Sometimes she would help clean up with the yellow and white cloth that she could suck and suck and sometimes get the taste of bubbles out of. She would go to her trolley, take out the potatoes and the chick-pea bottle and put them on the floor beside it, then go to the bath and fish out the plastic keys and put them in her trolley. Daisy would check the level of the dirt in the corners of the tray and if it was low she'd go to the large potted plant beside the bookshelf, put her hand flat on the dirt, then pull her fingers into a fist and take some dirt back to the trolley. She'd rub one hand on the other and wipe dirt into the tray of the trolley until the grains were fine. Then she would put the potatoes into the trolley, one by one, and finally, shaking it to make the chickpeas rattle loudly, she'd put the bottle back, always at the top by the handle. If it looked under-loaded she reached up and grabbed whatever came to her hand on the Formica table and put it in the trolley as well. Daisy pushed her trolley to the door and reached for the key and looked behind her for Alice or Lucas and if no one was there she would reach harder for the key and shout, 'Uh, uh,' until someone came and said, 'We're not going out at the moment.' Daisy would say, 'Uh, uh,' as if she felt they didn't understand her. When they walked away she would stamp her feet and cry out as loud as she could, 'Uh - Uh!'

This Saturday Lucas came back, holding a cardigan knitted in light blue wool with a hood and a draw cord through the neck of it. Alice came next, her jacket on, holding a pair of outside shoes for Daisy. Daisy leaned on Lucas's legs while she lifted one foot then the other to be shod, like a horse.

'You need to go backwards so we can open the gate,' Alice said. She had a bag on her back. Daisy had the trolley pushed right up to the gate. Alice's bag had a bell on it and a zip and Daisy had put a small plastic Alsatian in it last night before her bath. Daisy loved to push her trolley. She stopped under a large gum tree and looked up at tuis playing in the branches. The bark on the trunk peeled like a potato. Daisy squatted, picked up a piece of bark and put it in her trolley 
next to the water bottle Alice had added as they left. Then she stood, leaned back and watched the birds again. This is what it would have looked like from the road. A tall man, a short woman and a toddler, all heads leaned back looking up into the branches of a gum tree. The tuis flew away and Daisy took up pushing again. She felt like she could push forever. Just past the shops, Alice started saying, 'Bye, bye, Daisy,' and Daisy stopped and looked up at her from under the brim of her hat. The sun was out but there was no heat in it yet. Alice leaned down and kissed Daisy on the cheek. 'Bye bye,' she said. Lucas leaned down and kissed Alice on the cheek, 'Bye bye.' Alice turned and walked away. Daisy stood, both hands still on the trolley, watching Alice walk away. She looked up at Lucas and pointed at Alice. Lucas said, 'Bye bye, Alice.' She looked back and Alice was gone. She was standing around the corner of the dairy waiting, crying a little; her throat and eyes filling. This time, like every time, feeling like the last time she would see her. Alice peeked around the corner and Daisy was looking up at Lucas with one hand on the trolley handle and the other held out, opening and closing, into a fist, saying, 'Eye. Eye liss.' Then Daisy turned and pushed her trolley towards the park. 


\section{ACKNOWLEDGEMENTS}

With thanks to my friends and family for their support, the 2007 MA Class for their inspiration, and Damien Wilkins for his thoughtful and insightful supervision.

The 2007 PBS documentary Jonestown: The Life and Death of People's Temple served as both inspiration and source for I Believe in Jim Jones.

Haydon's Picture borrows from Benjamin Robert Haydon's journals and steals from William Hazlitt's magnificent essay On the Fear of Death, 1821. 